University of Louisville

ThinkIR: The University of Louisville's Institutional Repository

$12-2007$

\title{
Dismantling the master's house : deconstructing the roots of antiblack racism and the construction of the "other" in Judaism, Christianity and Islam.
}

John Chenault

University of Louisville

Follow this and additional works at: https://ir.library.louisville.edu/etd

Part of the African American Studies Commons, and the Religion Commons

\section{Recommended Citation}

Chenault, John, "Dismantling the master's house : deconstructing the roots of antiblack racism and the construction of the "other" in Judaism, Christianity and Islam." (2007). Electronic Theses and Dissertations. Paper 238.

https://doi.org/10.18297/etd/238

This Master's Thesis is brought to you for free and open access by ThinkIR: The University of Louisville's Institutional Repository. It has been accepted for inclusion in Electronic Theses and Dissertations by an authorized administrator of ThinkIR: The University of Louisville's Institutional Repository. This title appears here courtesy of the author, who has retained all other copyrights. For more information, please contact thinkir@louisville.edu. 


\title{
Dismantling the Master's House: Deconstructing the Roots of ANTIBLACK RACISM AND THE CONSTRUCTION OF THE “OTHER” IN JUDAISM, CHRISTIANITY AND ISLAM
}

\author{
By \\ John Chenault \\ M.S., University of Kentucky, 2006

\begin{abstract}
A Thesis
Submitted to the Faculty of the Graduate School of the University of Louisville in Partial Fulfillment of the Requirements for the Degree of
\end{abstract} \\ Master of Arts \\ Department of Pan African Studies \\ University of Louisville \\ Louisville, Kentucky
}

December 2007 
Copyright 2007 by John Chenault

All rights reserved 
Dismantling the Master's House: DeconstruCting THE RoOTS OF ANTIBLACK RACISM AND THE CONSTRUCTION OF THE “OTHER” IN JUDAISM, CHRISTIANITY AND ISLAM

$$
\text { By }
$$

John Chenault

M.S., University of Kentucky, 2006

A Thesis Approved on

November 28, 2007

by the following Thesis Committee:

Thesis Director 


\section{DEDICATION}

This thesis is dedicated to my wife

\section{Gwendline Harper Chenault}

whose love, support, wit, and wisdom

have made my life an oasis in the desert of the real. 


\section{ACKNOWLEDGeMents}

I want to extend my deepest appreciation to my thesis director, Dr. Robert L. Douglas, for his guidance, and especially for his patience during the time I placed this project on hold while completing an M.S. degree in library and information science. I also want to thank the other committee members, Dr. Blaine Hudson, Dr. Ricky Jones, and Professor Nefertiti Burton, for their patience and support. My academic advisor Dr. Theresa Rajack-Talley also deserves a special mention for her persistence and determination in making sure I completed this thesis. And to the other faculty members of the Department of Pan African Studies, and the graduate students, past and present, thank you for creating a vibrant learning atmosphere and for your dedication to advancing the work of "Black" Studies.

Finally, to my mentor, Jan R. Carew, I owe a debt that can never be repaid. I can think of no other human being whose life and scholarship better exemplifies the discipline of Pan African Studies and its centrality in the struggle for human rights worldwide. Nor can I think of any educator who is more generous with his time, advice and guidance for students. His genius inspired this research project. His scholarship and writing skills provided an illuminating example for me throughout the planning and writing of this thesis. I am truly grateful for his guidance and assistance. I am, however, solely responsible for the contents of this thesis and any errors it may contain 


\begin{abstract}
Dismantling THE Master's House: Deconstructing THE RoOTS OF ANTIBLACK RACISM AND THE CONSTRUCTION OF THE “OTHER” IN JUDAISM, CHRISTIANITY AND ISLAM

John Chenault
\end{abstract}

November 2007

This critical inquiry into the social constructions of "black" and "white" identities analyzes the roles of the three "western" monotheisms (Judaism, Christianity and Islam) in the cognitive and sociohistorical developments of racial slavery and antiblack racism. Specifically, it investigates the sociohistorical consequences of the inherent dualisms of the "western" monotheisms and how those dualisms are expressed in the production of social theories and systems that rely on believer/non-believer oppositions and binaries defined by a Manichaean view of the universe and a teleological conception of history that fosters and sustains an eternal holy war against infidels. What emerges from this analysis in the end is a reconnection of Islam with Judeo-Christianity, resulting in the (re)formulation of a Judeo-Christian-Islamic complex as a specific instrumentality in the formation of "white" and "black" identities and the creation and preservation of white supremacy. 


\section{TABLE OF CONTENTS}

ACKNOWLEDGEMENTS.............................................................iv

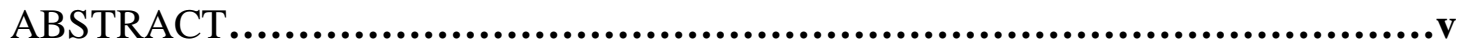

\section{CHAPTER}

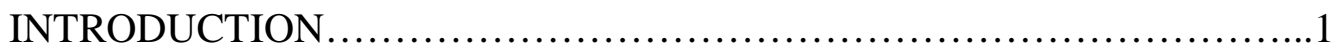

LITERATURE REVIEW ..............................................

THEORY \& METHODOLOGY ........................................... 15

Definition of Concepts: Monotheism...............................17

Definition of Concepts: Eurocentrism.............................28

Definition of Concepts: "Black Liberation Discourse (Afrocentrism)....35

Theoretical Problems: Trans-history/meta-theory......................52

THE SOCIAL CONSTRUCTION OF "RACE" .................................72

JUDAISM AND THE INVENTION OF THE COUNTERRELIGION ................87

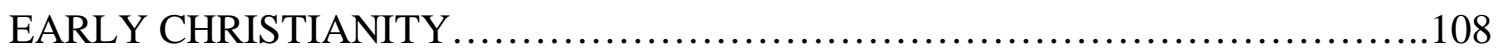

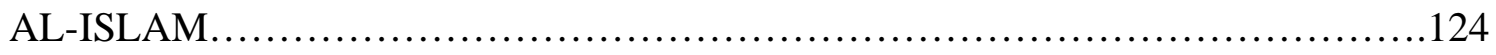

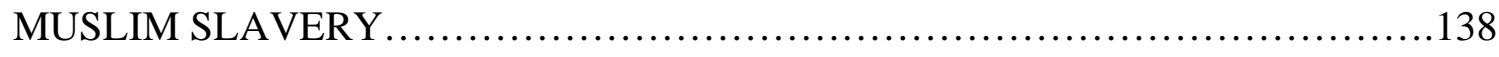

ISLAM AND THE DEVELOPMENT OF ANTIBLACK RACISM...................153

MOORS, TAWNY MOORS, BLACKAMOORS, AND ARABS $\ldots \ldots \ldots \ldots \ldots \ldots \ldots . \ldots 186$

RACIAL DISCOURSE AND DISCORD IN IBERIA..............................196

MOORISH SPARKS, EUROPEAN RENAISSANCE..............................205 
CONCLUSION.

REFERENCES........................................................... 227

CURRICULUM VITAE............................................... 245 


\section{INTRODUCTION}

Audre Lorde's famous declaration “The Master's Tools Will Never Dismantle the Master's House" originated within the paradigms of a "black" feminist discourse designed to confront and challenge the epistemological hegemony of a "racist patriarchy"(Lorde, 1984, p. 112). In the twenty-eight years that since have passed, the master's tools and the master's house have become nearly synonymous with Eurocentric epistemology and Eurocentrism, and a new generation of scholaractivists has taken up the challenge posed by her theorem. This research project owes its inspiration to the enduring power of Lorde's idea. And, like other post-colonialist studies that have followed in the wake of her assertion, it seeks to "dismantle" (deconstruct) the taxonomic systems and theories of knowledge the "West" has used to divide and conquer, marginalize and dismiss, and oppress and exploit the "rest of us." Taxonomic systems are systems of classification used to organize data into sets of information that can become knowable (Lincoln, 1989, p. 7). The information that constitutes what is "knowable" or "known" in this particular instance are concepts and ideas that together comprise the organizing principles of race as a mechanism of social stratification and human identity. This study therefore seeks to identify and investigate those taxonomies that have been central to the social construction of the master's house of Eurocentrism and the sociohistorical concepts that underlie the modern constructs of "black" and "white" identities. As Bruce Lincoln points out in Discourse and the Construction of Society: 
Taxonomy is thus not only an epistemological instrument (a means for organizing information), but it is also (as it comes to organize the organizers) an instrument for the construction of society. And to the extent that taxonomies are socially determined, hegemonic taxonomies will tend to reproduce the same hierarchic system of which they themselves are a product (1989, pp. 7-8).

The ideology of white supremacy, the organizing principle of Eurocentrism, creates a hierarchic system that socially organizes and categorizes both the objects of its epistemological violence (those whom it exploits and oppresses) and its subjects (those who "know" and reproduce the sociology of knowledge that supports and sustains it). By this means it constructs a social order based on the codes and imperatives of a "racial contract" that "establishes a fundamental partition in the social ontology of the planet ..." (C. W. Mills, 1997, p. 55). That "partition" effectively separates the West from the rest of us in its presentation as an impassable divide between "white" persons and nonwhite "others" (Du Bois' color line). This thesis locates and identifies the cognitive origins of this social dichotomy and examines the mechanisms and events that led to its formularization in the binary categories of "black" and "white."

Racism was and is the blunt instrument of European hegemony. The imposition of racial identity, the dehumanizing rhetoric of racial discourse, and the pervasive psychological violence of the Eurocentric episteme have been far more instrumental in the institutionalization and maintenance of the white supremacist regime than the exercise of brute physical force. Even the symbolic acts of racist discourse-"white" frat brothers cavorting in blackface, hangman's nooses displayed in schoolyards, swastikas graffitied on headstones in Jewish graveyards—-serve as brutal reminders that the idioms and iconography of this system can be as oppressive and destructive as actual physical violence. The taxonomies that structure and support this discourse of white 
supremacy/black inferiority also constitute the epistemological tools used to posit, police, and psychologically maintain the existential borders of the racial state according to the strict codes of the racial contract. How then are these borders and boundaries and the hegemonic sociology of knowledge that informs them to be confronted and contested? The theoretical approach used here starts with the idea of a decolonization of knowledge using a double critique and border thinking - the conceptual basis of which is explicated and discussed in the methodology section below. Although these concepts emerged from an analysis of European and Islamic fundamentalisms and their intersections (a subject that will be explored in-depth in this thesis), the "double critique" also is applied here to both Eurocentric and African-centered thought. Walter Mignolo-referring to Moroccan philosopher's Abdelhebir Khatibi's work on "Occidentalism," the "Creolization" concept of Martinican philosopher Edouard Glissant, and Argentine philosopher Enrique Dussel's "myth of modernity,"-posits this "double critique" as creating the conditions for the emergence of an "other thinking." He defines this "other thinking" as:

[...] a way of thinking that is not inspired in its own limitations and is not intended to dominate and to humiliate; a way of thinking that is universally marginal, fragmentary, and unachieved; and as such, a way of thinking that, because universally marginal and fragmentary is not ethnocidal (Mignolo, 2000, p. 68).

The "other thinking" perspective, the ability to think, speak and act as "Other," provides an ethical alternative to the genocidal logic of the modern world system of white supremacy, and an escape from the self-referential pseudo-universalizing tautologies of centrist ideologies-irrespective of whether such ideas emerge from Euro- or Afrocentered thinking. Much of the interpretative and explanatory power of this study rests, therefore, on the effort to locate and define a perspective that lets us view the "master's" 
narrative and the counternarratives of notable "black" intellectuals (and others) from both within and without the cognitive events surrounding their sociohistorical constructions, and at the intersections of their confrontations with each other. The "double critique" process needed to perform an "other thinking" and the "other thinking" itself suggest the involvement of a "double-consciousness," not unlike the theory that informs Du Bois' idea of the same. This study argues, however, that self-awareness and recognition of a "double-consciousness" (or self-awareness of one's otherness) does not itself signal a "liberation" or constitute a form of "liberation" from the hegemonic violence of Eurocentric epistemology; nor does it necessarily illuminate the ways in which "black" liberation discourses (African-centered thought) often are premised within Eurocentric theories of race and history. Self-awareness as "other"-as conceived and defined by one's oppressors-may be catalytic in fostering agency and motivating the will to resist and overcome, but liberating the "black" body does not necessarily free the "black" mind. As Lewis R. Gordon correctly points out: "Black Studies/African American Studies/Africana Studies was born with the express purpose of decolonizing the minds of people, especially black people" (author's italics) (2006a, p. x). Gordon also suggests intellectual capital used in pursuit of liberation theory is better spent in "transcending rather than dismantling [the] Western ideas" that inform the master's house. He respectfully rejects what he sees as Lorde's mischaracterization of the "master's tools" and argues old tools can be used to create counterhegemonic tools that can resist and combat the consequences of what he calls epistemological colonization (Gordon \& Gordon, 2006a, p. xi). 
Questions and concerns about the "tools" used by "black" scholars to resist and combat epistemological colonization led me to examine the sociohistorical roots of "black" identity and its sociohistorical development within a Eurocentric milieu. It also led me to understand and define the earliest form of black liberation discourse (Africancentered thought) as a type of strategic essentialism for self-defense and self-preservation actuated by the existential reality of antiblack racism. Thus early "black" scholars responded or reacted to the blackness that was invented and imposed on them by "white" oppressors by transforming it into a "tool" for survival and a weapon for liberation.

Although this thesis does not examine in detail the specific discursive and didactic features of early black liberation discourses, it does use as its starting point the paradigm of black studies established by "black" thinkers in the first half of the nineteenth century. Key organizing principles of that paradigm are based on biblical discourses and the efforts of early "black" activist-scholars to find within the Bible's texts moral and spiritual solutions to the problems of racial slavery, injustice and inequality. The theory and practice of black liberation discourse therefore has been informed and influenced by the religious beliefs and practices of African Americans since its founding. Thus it is important to examine the complex function of "race" and racism in the religious faiths that sanctioned and promoted the enslavement of Africans, and that Africans in America sought to reinterpret and reform with their liberation discourses. This critical inquiry into the social constructions of "black" and "white" identities analyzes the roles of the three "western" monotheisms (Judaism, Christianity and Islam) in the cognitive and sociohistorical developments of racial slavery and antiblack racism. Specifically, it investigates the sociohistorical consequences of the inherent dualisms of the "western" 
monotheisms and how those dualisms are expressed in the production of social theories and systems that rely on believer/non-believer oppositions and binaries defined by a Manichaean view of the universe and a teleological conception of history that fosters and sustains an eternal holy war against infidels. What emerges from this analysis in the end is a reconnection of Islam with Judeo-Christianity, resulting in the (re)formulation of a Judeo-Christian-Islamic complex as a specific instrumentality in the formation of "white" and "black" identities and the creation and preservation of white supremacy.

The several chapters that follow outline the origins and development of Judaism, Christianity, and Islam, and trace how racist myths and symbols in these belief systems provided the justifications and rationalizations for the mass enslavement and exploitation of African peoples. Islam and the ethnographic theories and beliefs of Muslim societies receive the bulk of the attention in this study. The role of Islam in the African slave trade and in the formation of both "black" identity and European-centered thought warrants much more investigation and analysis. Several notable studies address the Islamic slave trade in Africa and its impact on African societies, but the role of Islam as a central factor in the formation of "black" identity and Eurocentric thought has received far too little treatment. The research presented here is designed to address some of those gaps in our understanding of these sociohistorical constructions.

Audre Lorde was resolute in her refusal of the possibility of the master's tools dismantling the master's house. She succinctly stated her doubts as follows: "They may allow us to temporarily beat him at his own game, but they will never enable us to bring about genuine change” (Lorde, 1984, p. 112). Lewis R. Gordon, in his “insider' s” critique and constructive engagement with Lorde's suppositions, argues for the erection of "new 
houses" with "new tools." He contends: "When enough houses are built, the hegemony of the master's house - in fact, mastery itself-will cease to maintain its imperial status" (author's italics) (Gordon \& Gordon, 2006a, p. xi). The methodological strategy chosen for this thesis is to negotiate between these two poles of deconstruction/construction to build a new house (new domain of knowledge) in a "decolonialized" neighborhood far beyond the boundaries of Eurocentrism. This thesis comprises my set of blueprints. 


\section{LITERATURE REVIEW}

This literature review presents an overview of the theory and methods used in the selection of key texts for study and analysis. I chose this approach because many of the key texts cited in this thesis are discussed within the contexts in which they are referenced. Consequently, I have minimized the discussion here to avoid redundancy and to focus on a few key issues and concerns that require explanation or clarification.

As a research project grounded in the field of Pan African studies, this thesis draws from several disciplines including mythology, religion, sociology, history, anthropology and philosophy. The chronological scope of this research project also spans several millennia of diverse human sociohistorical developments and events. Needless to say, the ambitious nature of this project and its particular theoretical approach requires a familiarity with a broad array of scholars, theories, methodologies and texts from multiple fields of study. My own diverse interests in historiography and my library training provided some advantages from the outset in identifying and selecting materials pertinent to this endeavor. I also relied heavily on the materials in my personal print and electronic libraries, the majority of which consist of primary research materials and key texts in Pan African and related areas of study. Thus by means of these specialized resources and the electronic and print resources of the library, I was able to access the materials needed to complete this research project. 
My goal of deconstructing the Eurocentric biases in western culture and scholarship, particularly in terms of the study of "western" religions and monotheisms, required me to review key theoretical studies that would help in formulating my own theoretical approach to my topic. Additionally, I needed materials that also would enable me to understand the historiographic and philosophic traditions upon which various theories and methods were formed and informed. With these goals in mind, I decided to locate and classify the larger and general set of theoretical literature into two basic categories: items written from a Pan African perspective; and those items that emerged from other traditions such as post-structuralism, deconstructionism, post-colonialist studies, and critical race theory. While admittedly some overlapping occurs between the two categories of general theoretical literature (as is the case with the other categories listed below), I still felt it was important to my research strategy to delineate these materials on the basis of their origination or locus of enunciation regardless of their concurrences or lack thereof. In the domain of Pan African theory-a category that includes a wide array of theorists from all sectors of the African Diaspora-I relied extensively on the work of St. Clair Drake $(1987,1990)$ for his comprehensive treatment and analysis of the social construction of race in the fields of Egyptology, sociology, anthropology, and religion. Additionally, I consulted works by Anthony Appiah (1992), Jan Carew (1994; 1988), Amie Cesairé (1972), Chinweizu (1975), Cheikh Anta Diop (1974, 1978), W. E. B. Du Bois (1946), Frantz Fanon (1965, 1967; 1968), Lewis G. Gordon (1997; 2006b), John G. Jackson (1970, 1985), Kandiatu Kanneh (1998), Maghan Keita (1994, 2000, 2001, 2002, 2005), Charles Mills (1997), Wilson J. Moses (1998), V. Y. Mudimbe (1988), Ivan Van Sertima (1985, 1992), Frank Snowden (1970, 1983), 
Chancellor Williams (1974), and Michelle M. Wright (2004). While the above list is by no means exhaustive, the work of these scholars proved essential in shaping my overall research strategy and in providing a general background to theoretical issues of special concern in the construction of "black" liberation discourses.

The "other" theoretical literature of particular use to me in this study came from a variety of Asian, European, Euro-American, Latin American, and Middle Eastern sources. The most noteworthy of these are studies by Samir Amin (1989), Bill Ashcroft (1998), Peter L. Berger \& Thomas Luckmann (1967), Martin Bernal (1987), James M. Blaut (2000; 1993), Ernst Breisach (1994), Enrique Dussel (2000; 1993), Johannes Fabian (2002), Michel Foucault (1994; 2003), Jack Goody (1986, 2004, 2006), John Hobson (2004), Abdul R. JanMohammad (1985), Bruce Lincoln (1989), Walter D. Mignolo (2003; 2000), Sara Mills (2004), Fernando Ortiz (1995), Roy Porter (2000), Jose Rabasa (1993), Joseph Roach (1996), Edward Said (1994), Robert J.C. Young (1990, 1995), and Slavoj Zizek (2002). Several of the scholars listed above have produced key texts that deconstruct and expose the Eurocentric bias in western scholarship. Books and articles by Martin Bernal, James Blaut, Enrique Dussel, Jack Goody, John Hobson, Jose Rabasa, and Robert J.C. Young, in particular, provided great insight into the "white mythologies" perpetrated as history by Eurocentric scholars. Martin Bernal's "Aryan Model" of the origins of western civilization navigates a path outlined in the work of George G.M. James (1954) three decades earlier. Both influenced my thinking about how modern European identity is built on a model of "classical civilization" that obscures its Afroasian roots. The work of Walter D. Mignolo provided core components of the theoretical framework applied throughout this study, especially his concept of border 
thinking. Blaut, Goody, and Hobson furnished essential correctives to European history and historiography, revising the chronology of economic and technological "progress" in Europe and situating it in its proper relationship to cultural, economic and technical developments in other regions of the world, especially Asia.

The study of the emergence of the three monotheisms (Judaism, Christianity, and Islam) requires careful evaluation of sources, given the tendency of many scholars in the field of religion to accept unquestioningly the premises and purported historical value and veracity of religious texts. Keeping these issues in mind, I reviewed the works of Karen Armstrong (1993), F.E. Peters (1991, 2003a, 2003b), and Rodney Stark (2003) for insights into the traditional paradigms in the study of monotheism (Stark), and Judaism, Christianity and Islam (Armstrong; Peters). Christos Evangeliou (2003), Jonathan Kirsch (2004), and Regina M. Schwartz (1997) offered thoughtful materials on the violent legacy of monotheism in western culture and history. The work of German Egyptologist Jan Assmann (1996, 1997, 2001), however, set the standard in my approach to the origin and evolution of monotheism and its impact on the ancient world. Assmann's work introduced me to George Spencer Brown's "first law of construction," a concept of mathematics and logic that also applies to the procedures and processes that inform the social construction of knowledge.

To understand the emergence of Judaism in the ancient world, I relied extensively on studies by Thomas Thompson $(1999 ; 2005)$ and Mark S. Smith (2001), two scholars whose use of archeology, linguistics, and mythology and folklore in the study of the origins of Judaism and Christianity has revolutionized these fields. Karen R. Andriolo (1973) furnished an excellent overview of how the worldview expressed in the Old 
Testament informed and structured concepts of Jewish identity and genealogy. For scholarly views of the construction and canonization of the Bible, I referred to works by Israel Finkelstein \& N.A. Silberman (2001), W.M. Schniedewind (2004), and A.N. Wilson (1992). I used texts by Karen Armstrong (1993), John Dominic Crossan (1998), Robin Lane Fox (1986), John G. Jackson (1985), and A.N. Wilson (1992) as guides for understanding the origins and development of Christianity. And it also should be noted here, all references to the Old Testament and New Testament have been taken from an authorized King James Version of the Bible (1999) edited by Barry Mosher. This study did not require any particular translation of biblical verses for its analysis or interpretation. Consequently, I chose a commonly accepted version for my purposes.

For the traditional paradigm of Islamic studies, I relied on the work of Karen Armstrong (1993), Reza Aslan (2006), Carl Brockelmann (1960), and F.E. Peters (1991, 2003a, 2003b). The traditional paradigm of Islam, like that of Judaism and Christianity, is grounded in accounts of the religion's origins as presented by its sacred texts and their interpreters. A new paradigm emerged over the last few decades that cast the origins and development of Islam in an entirely new light. Ibn Warraq (1998b, 2000b) is a leading scholar in this effort. He has edited and contributed to a series of essential reference works noted for their critical analysis of Islamic history. Warraq's publications were an essential resource in developing the perspective on Islam presented in this study. The passages from the Quran cited in this thesis were taken from a translation by Abdullah Yusuf Ali (1983).

I found much useful material to address the role of religion in the construction of ethnicity and race in books and articles by Aziz al-Azmeh (1992), Roger Bastide (1967), 
James Brunson \& Runoko Rashidi (1992), Gay L. Byron (2002), David Brion Davis (1984), St. Clair Drake (1987, 1990), I. Ephal (1976), Peter Frost (1991), David M. Goldenberg (2003), Michael Gomez (1998), Robert E. Hood (1994), Graham W. Irwin (1977), Bernard Lewis (1982, 1985), Jonathan Schorsch (2004), Ronald Segal (2001), and Werner Sollors (1997). For the history of "race" as a social construction, I used works by Theodore Allen (1994), C. Loring Brace (2005), Oliver C. Cox (1945, 1948), St. Clair Drake (1987, 1990), Jack Forbes (1993), George M. Fredrickson (2002), Ivan Hannaford (1996), Benjamin Isaac (2006; 2004), Winthrop D. Jordan (1968, 1974), James H. Sweet (1997), and Lloyd A. Thompson (1989). Charles W. Mills' The Racial Contract (1997) furnished important insights into the development of white supremacy and was a major influence on my thinking throughout this project.

Books and articles by Samir Amin (1989, 1997), Robin Blackburn (1997a, 1997b), Benjamin Braude (1997), Moses I. Finley (1998), John Hunwick \& Eva Trout Powell (2002), Herbert S. Klein (1999), Martin Klein (1992), Bernard Lewis (1982, 1985), Orlando Patterson (1982), and Ronald Segal (2001) comprised a major component of the basic resource materials I used to research slavery and the development of racial slavery.

The rise and expansion of Islam, and the Moorish invasion and occupation of Iberia, both receive considerable treatment in this thesis. Books and articles by A.G. Bostom (2005), Jan Carew (1992, 1994; 1988), David Brion Davis (1984), William McKee Evans (1980), Richard Fletcher (1992), Paul Fregosi (1998), Graham Irwin (1977), Stanley Lane-Poole (1886), Maria R. Menocal (2002), Daniel Pipes (1980), and 
Richard E. Rubenstein (2003) served as the main reference materials for research into this aspect of my thesis.

Finally, I believe the literature selected for review and analysis in this study well represents the disciplines and topics involved. My selection criteria emphasized the collection of the newest research materials available on a given subject as well as the inclusion of groundbreaking studies by the earliest known scholars in the various fields. I also sought to review materials from scholars who were highly critical or directly opposed to the theoretical perspectives I brought to this study. By this means I hoped to both familiarize myself with diverse and divergent opinions and to strengthen or modify my arguments as needed. The biggest challenge for me throughout this process was deciding when enough was enough. 


\section{THEORY \& METHODOLOGY}

\section{Introduction}

This study takes the form of a counterhegemonic discourse in the tradition of Pan African and African-centered scholarship and in its conduct of intellectual warfare against white supremacy. Thus the rhetorical act of "dismantling" articulated in its title serves as a central metaphor for both the theory and methodology of the liberation discourse employed herein, and the analysis and critique of its principal object of investigation: the sociohistorical constructions and taxonomies of "blackness." While critical theory and its offshoot, critical race theory, provided key interpretive methods and strategies in the formation of this study, ultimately, given my own predilections as a bricoleur, I approached this research project as a bricolage. In other words, in the tradition of a professional "jack of all trades," I chose the research theories and practices that guided this project based on the questions asked and their specific contexts to produce a work that could navigate within and between particular epistemologies and methodologies, and within and between various competing paradigms and perspectives. And, in the multidisciplinary spirit of Pan African Studies, I drew from diverse human disciplinescomparative mythology, comparative religion, sociology, anthropology, history, historiography, ethnography, philosophy, classical studies and cultural studies- to produce a complex analysis and synthesis that represents my interpretation and understanding of the subjects of investigation of this thesis. The merit of this approach, in my opinion, rests not with its conclusions, but with its heuristic process of identifying and 
investigating critical problems faced by scholar-activists in the struggle to dismantle the ideological structures and infrastructures of white supremacy. The sections that follow provide definitions for key terms used in this study, and an extended discussion of important theoretical and methodological problems germane to this research project. 


\section{Definition of Concepts: Monotheism}

I will give the name, 'deconstruction of monotheism', to the research project consisting in the dismantling and analysis of the constitutive elements of monotheism, and more directly of Christianity, thus of the West, in order to go back to (or proceed toward) the resources that might form simultaneously the buried origin and the imperceptible future of the world that calls itself 'modern' (Nancy, 2003).

Monotheism, simply defined, means: the doctrine or belief that there is only one God. Since this religious ideology informs and influences every aspect of modern western society and identity—as it has been translated over time from "the sphere of the sacred to nationalism, and thence to other collective identities"-it hardly seems necessary to define it (Schwartz, 1997, p. 16). But what do we really know about OneGod-ism? We know Judaism, Christianity and Islam, the three monotheistic faiths, share a belief that: "only a single deity is worthy of worship for the simple reason that only a single deity exists" (italics added) (Kirsch, 2004, p. 9). We know this single deity is variously called "Yahweh" or "Lord" or "Allah." We know each of these religions has produced a sacred text that purportedly documents the revelation of the one true god and his doctrine, and that the believers in these traditions view their sacred books as true and unassailable. But what do we really know about the origins and evolution of monotheism, its sociohistorical development, its various practices, and the ancient texts that authorize, historicize and document its religious ideology?

This thesis addresses the above questions with a particular goal of investigating the role of the monotheisms in the formation of collective identities based on the believer/nonbeliever dichotomy that defines and determines membership (and exclusion) in the monotheistic faiths. This thesis also looks at an inherent contradiction in the concept and practice of monotheism: the problem of dualism in Judaism, Christianity and 
Islam. Although this problem arises at the conceptual level (the manner in which human beings conceive and theorize the godhead), it has important implications for monotheism as praxis. As Rodney Stark points out in For the Glory of God: "In practice, absolute monotheism is possible only when the supernatural is conceived of not as a being but as an essence, as an impersonal, remote, divine principle such as the Tao" (author's emphasis) (2003, p. 10). Stark uses the term "supernatural" to denote: "forces or entities (conscious or not) that are beyond or outside nature and which can suspend, alter, or ignore physical forces" (author's emphasis) (2003, p. 4). "Gods," then, are a particular form of the supernatural consisting of "conscious supernatural beings" (author's emphasis) (2003, p. 4). Stark assumes God is an entity or force beyond nature and employs the term supernatural to describe the nature of God(s) whether viewed from the perspective of monotheism or cosmotheism. As the term cosmotheism implies, it is possible to view God(s) as the cosmos. In this instance theogony and cosmogony (the origin of $\operatorname{god}(s)$ and the origin of the cosmos) are one and the same. When viewed from the perspective of Ancient Egyptian beliefs or other so-called pagan spiritual traditions, the relationship between the one god and the many gods on the one hand, and God and the world, or the creator and the creation on the other hand, can be seen as just aspects of the same question. Thus, according to the cosmotheist belief system (a system that precedes the "revelations" of the three western' monotheisms), rather than being beyond nature the divine or divinity (whether seen as one or as an aggregation of many) both manifests and inhabits the natural world and everything in and outside it. This form of natural "religion" or nature worship is the exact antithesis of Judeo-Christian-Islamic beliefs (Assmann, 2001). 
Stark's idea of the supernatural nature of $\operatorname{god}(\mathrm{s}$ ) (an idea that is consonant in the three monotheisms) is grounded in a view of creator, creation and the act of creating as separate and distinct spheres of being and action—as actor (god) and action (creation) and the product of action (the universe). From this perspective god and nature are separate and distinct in their nature and being — God is one thing, nature is something else, something that in fact can be seen as ungodly. The cosmotheistic view of god(s) as nature and god(s) in nature does not necessarily recognize or accept the notion that god is therefore super natural, except in the sense that the cosmos and everything in it exists in the same super or extraordinary state of consciousness and being. In citing the problematic nature of term supernatural, however, I do not want to lose sight of the initial quotation from Stark and how, by definition, it limits and qualifies the practice of absolute monotheism. Stark posits absolute monotheism as practicable only in godless religions. This view is grounded in his recognition of a central paradox in monotheism. Stark explains:

... although monotheism means belief in only one God, in none of the great monotheisms-Judaism, Christianity, or Islam-is there only one supernatural entity. In each, God is surrounded by a cloud of beings ... This necessarily limits monotheism since, in order for a divine being to be rational and benign, it is necessary for the religious system to postulate the existence of other, if far lesser, beings. That is, evil supernatural beings such as Satan are essential to the most rational conception of divinity. Thus Judaism, Christianity, and Islam are dualistic monotheisms — each teaches that, in addition to a supreme divine being, there also exists at least one evil, if less powerful, supernatural being. As Jeffrey Burton Russell put it, "Dualism posits two opposite powers of good and evil, attributing evil to the will of a malign spirit." The principle of dualism reflects the necessity either to conceive of a single divine essence [emphasis added] that is above the question of good or evil by virtue of being remote from any exchanges with human (the Tao), or to admit the existence of more than one supernatural being (author's emphasis) (2003, pp. 10-11). 
Differences in the godly and godless conceptions of the divine therefore engender different human customs and cultures. Those who posit and subscribe to the idea of the divine as a supreme essence, utterly impersonal and remote from human affairs, do not have to be concerned with the idea that this essence is responsible for any of life's vicissitudes. Those who believe in a supreme being, on the other hand, in practice, cannot allow that being to be responsible for the evil, irrational and bad things that happen in the world every day. Thus the western brand of monotheism is grounded in a theological dualism, which constructs and authorizes other internal or metaphysical divisions based on the irreconcilable categories of good and evil. As will be discussed below in this thesis, this theological dualism in the Judeo-Christian-Islamic monotheisms provides, via the believer/non-believer binary, a template for the extrapolation of this "religious" distinction into a distinction based on the illusion of race. But let us return now back to the crucial distinction in monotheism between those who posit a Supreme Being and those who posit a Supreme Essence to explain the nature of the divine. For Stark this distinction marks the difference between godly and godless monotheisms. Taoism and Confucianism exemplify the godless variety. Meditation and mysticism constitute the principal practices associated with these beliefs, but not worship. Stark contends godless monotheisms (which are not only found in the East) generally are less appealing, and incorporate in their "popular forms" a "substantial pantheon of Gods" to make themselves more attractive and accessible to the masses (2003, p. 5). Stark believes people prefer godly religions: "Because Gods are the only plausible sources of many things people desire intensely" (2003, p. 5). Such desires can be for material "things" or for peace, freedom, inspiration or a host of other "rewards of the spirit" (Stark, 2003, p. 
5). Prayers, rituals and offerings constitute the modes of exchange and principal methods of communication between humans and god(s). More important, where godless religions motivate their adherents to seek enlightenment through a conscious integration of the individual "self" with the "absolute" self that constitutes the essence of all existence or non-existence, "Godly religions rest upon revelations, on communications believed to come from the Gods" (author's emphasis) (Stark, 2003, p. 5). Divine communication from the Supreme Being therefore inspires and informs religious practices and modes of worship, and religious theory in the form of theology. According to Stark: "theology consists of explanations that justify and specify the terms of exchange with Gods, based on reasoning about revelations" (author's emphasis) (2003, p. 5). Such explanations also affirm, through their expression and institutionalization in the religion's cult(ural) customs and behaviors, the truth, legitimacy and efficacy of its precepts and practices. It is here that a religion's revelators and specialists (theologians, priests, and sages) prove most compelling and persuasive. Stark notes: "Since the ultimate proofs of religious claims typically lie beyond direct examination, it is through the testimony of others that people gain confidence in a religion" (2003, p. 7).

Dualistic monotheism as defined by Stark, points to an inherent problem with monotheism-its denial of agency. God, in the monotheist conception must be good, and thus its explanations for evil rests on extra-divine force or forces that are supernatural but not supranatural in that they cannot exceed the authority and power of the one god. Contradictions abound in this formulation, contradictions that undermine the singularity or unity of the monotheistic godhead. Thus a dichotomy arises in the form of the struggle 
between good and evil. This irreconcilable and eternal antagonism lies at the roots of the believer/non-believer dichotomy that also informs the western monotheisms.

The psychosocial events that provide the contexts and conditions for the emergence of the monotheism of early Israel, in particular, as delineated by the quote below, adumbrate later discussions in this thesis about the process of othering as it relates to religious identity. Mark S. Smith sets the stage for us with this observation:

Within the Bible, monotheism is not a separate "stage" of religion in ancient Israel, as it is customarily regarded. It was in fact a kind of ancient rhetoric reinforcing Israel's exclusive relationship with its deity. Monotheism is a kind of inner community discourse using the language of Yahweh's exceptional divine status over and in all reality ("there are no other deities but me") in order to absolutize Yahweh's claim on Israel and to express Israel's ultimate fidelity to Yahweh in the face of a world where political boundaries or institutions no longer offered sufficiently intelligible lines of religious identity. In its political and social reduction in the world (first because of the rise of the foreign empires in the seventh century followed by its exile in 587-583), Israel's elevated the terms of its understanding of its deity's mastery of the world. [...] Put summarily: Israel was now no nation, but the gods of other nations, including the greatest powers, were not really gods; and Yahweh was the sole force over both (2001, p. 9).

Here, Smith illuminates two salient points that will be considered below:

monotheism as a form of rhetoric, which, in this case, applies to its "revelation" within the larger context of polytheism (cosmotheism), and the use of monotheism to erect and police ideological boundaries and formulate religious identity. Smith also reminds us that: "comparing ancient polytheistic religions with a monotheistic one is anachronistic, as the term "polytheism" only has any meaning or sense because it is contrasted with monotheism" (2001, p. 11). Neither of these terms meant anything to the ancient cultures involved. Early Israel's version of monotheism evolved over hundreds of years, appearing in its earliest textual forms sometime in the seventh century BCE (Finkelstein \& Silberman, 2001; Smith, 2001). And, as texts and artifacts indicate, Israelites continued 
to worship other gods throughout their early history, practicing to varying degrees what could be described as Henotheism (Schwartz, 1997; Smith, 2001). Henotheism (also known as monolatry) is a term coined by Max Muller. It means devotion to a single god while accepting the existence of other gods. Most of the Old Testament can be described as henotheistic. Thus the early religious worldview of the ancient Israelites shared many common features with its Iron Age neighbors in North Africa, the Levant, and Mesopotamia (Smith, 2001).

Smith offers several other vital points to consider as we define monotheism. First he notes the fallacy of presentism, as mentioned above, in the conceptualization of monotheism:

The concept of monotheism reflects our modern situation as much as the circumstances of ancient Israel or the Bible, for monotheism is largely a modern concern. Monotheism's importance perhaps derived in part from contact between modern Europeans and non-Westerners, as a way of defining the Western religious tradition in contrast to non-European cultures (Smith, 2001, p. 11).

Smith's statement also identifies and recognizes the role of monotheism in the ideological structuring and construction of modern Western identity, but sees this process as a modern reactionary phenomenon. Here it is argued that this process of self-definition in the West coheres during the so-called European Middle Ages when the conflicts and confrontations between European and Islamic societies heighten the contradictions between these two monotheisms and produced a territorial definition of the West as Christendom. Although the roots of the concept of Christendom are to be found in Jewish theocratic traditions, the idea makes a significant appearance in Europe with the reign of Constantine in the fourth century $\mathrm{CE}$, and expands with the founding of the Holy Roman Empire under Charlemagne in the ninth century CE (Mastnak, 2002). Therefore, in 
medieval times the lands under the auspices of the Roman Church "were thought of as Christendom, not Europe per se" (Blaut, 2000, p. 4). Christendom thus represented the concept of "god's land" for Europeans, as did land of Israel for Jews and the dar al-Islam (abode of Islam) for Muslims (Tibi, 2005, p. 327).

Monotheism continued to occupy and perform a prominent role in western culture even after the movement toward secularization in most European societies during the socalled European Age of Enlightenment. As a core component of western consciousness it influences every aspect of Euro-American social development and the institutions that comprise the building blocks of western social identity—including and especially the formation and constitution of the secular democratic state. According to Smith:

Monotheism has served as the "sublime idea" in Western civilization in contrast to (or to avoid?) the contentious differences in actual beliefs and practices. For an increasingly secularized culture, monotheism could serve as a substitute for religious beliefs and rituals, some of which might be seen as primitive for some highly "cultured" Westerners ... monotheism in part serves an essentially liberal point of view (theologically and politically speaking), with little connection to explicit religious tradition or praxis (2001, p. 11).

While monotheism may function as a "substitute for religious beliefs" in supporting the "liberal" tradition in Western culture, it nonetheless maintains its structure of dualism and binary oppositions. Consequently, the basic monotheistic formulary used to structure society in the modern secular West replicates the fundamental distinctions between believers (in this case, those who are recognized as members of the polity and thus eligible to benefit from its rights and privileges), and nonbelievers (those who are excluded from full membership for whatever reasons: caste, race, gender, economic status, etc.). In the medieval era the boundaries between Christendom and Islam demarcated "religious" distinctions (as did the boundaries between the monotheisms and 
so-called pagan faiths). The "religious" identities fostered by these distinctions provided the cognitive ground that conditioned and contextualized "national" identities and nationalism. The formation of modern Western nation-states, rather than breaking with this pattern of identity formation merely transformed and continued it in new guises and disguises. According to Regina M. Schwartz, the ancient view embodied in the biblical narrative of the so-called Deuteronomistic history (Judges through 2 Kings of the Hebrew Bible) — which sees the true nation (Israel) as worshipping the true god and all other nations as worshipping false gods-is clearly reflected in the formation of the modern nation-state:

In theory, Christendom seemed to incorporate many nations under one God, with the spread of Christianity's monotheism creating one holy empire. But in practice, when more or less secular nations were carved out of that empire, each had its version of a tutelary deity: instead of one God who spoke Latin, the French God spoke French, the German God spoke German, the English God spoke English (with an Oxbridge accent) and the U.S. God spoke English (with a southern accent). Nonetheless, these nations were still under recognizably the same God, despite his various linguistic, cultural, and national manifestations - the God of the West - and he was differentiated from the pagan deities of the East (Schwartz, 1997, p. 121).

"One nation under God"-is the pledge taken by countless schoolchildren daily in classrooms across the U.S. It is a statement often cited by fundamentalist Christians to advance the establishment of a theocratic form of government over the United States. In its basic formulation it incorporates monotheistic dualism to instantiate a nationalistic distinction between members of the American polity and others.

One final point needs to be made before moving to the next definition. Not one of the revelators of the monotheisms (Moses, Jesus, Mohammad) ever wrote a single word of what came to comprise the sacred books of their respective faiths. Yet the very concept of monotheism and the notion of religion itself could not exist in its various forms today 
without the written word and, more specifically, the invention of the alphabet. Jack Goody, in his groundbreaking study of literacy, family, culture, and the state, analyzes and assesses the impact of writing on human societies and explains how religions organized themselves and societies though their early control of literacy and through their roles as the producers, curators, interpreters and disseminators of 'sacred' texts. Goody contends:

With writing a new situation arises since the priest has privileged access to the sacred texts (whether in the singular or plural) of which he is the custodian and prime interpreter. As a mediator he has a unique link to God, whose Word only he is often able to read. In the beginning was the Book, but it was the priest who read and explained it. Hence religions of the Book are often associated with restrictions on the uses and extent of literacy (1986, p. 17).

Religions of the Book (Judaism, Christianity and Islam) deeply invest in policing the written word of god and advancing it over all other discourses. Thus monotheists give considerable attention to the production and reproduction of authorized texts, the removal and condemnation of texts considered spurious or heretical and the assertion of what are purported to be god's written law or commands over and above those deemed to be man made. This focus on the authority of the book and the inerrancy of the word of god often creates conflict and dissension in secular societies that accept or tolerate religious diversity.

For those societies described as oral or non-literate, problems of policing and controlling belief systems generally do not exist. In such cases religion is not a distinct element in the social matrix; it is the social matrix. When the belief systems and the social systems are one in the same there are no religious boundaries to police and protect because the concept of religion does not exist. This is true in the case of most so-called traditional African societies. Most African languages do not even possess a word for 
"religion" because no cognitive distinctions are made between so-called religious practices or any other normative behaviors; all are viewed as part of the typical way of life (Goody, 1986, p. 4). Consequently, laws and codes of ethics are situational and embodied in the specific contexts in which they are relevant or applicable. In monotheist societies the opposite is often true, as Goody points out:

Once literacy enters into interpersonal communication, then good and evil tend (though not immediately) to be written down and systematized as a code of law or ethics. Ideals embodied in a text rather than a context are no longer attached to present concerns in the same tight way; an old eschatology may persist or a new one be created which conflicts, by accident or design, by interest or essence, with other aspects of the socio-cultural tradition. In other words, religion can become a relatively distinct element in the social matrix, both manifesting and creating a greater complexity of beliefs and practices (1986, p. 21).

These distinctions between oral and literate cultures played a significant role in the encounters between certain African societies and Muslims and Christians. For example, the people without the Book more often than not perceived themselves to be at a decided disadvantage to the people with the Book due to the impression that the written word of god was more effective and its interpreters more powerful. In such encounters the people with the Book assumed they were superior and, as will be discussed in the chapters that follow below, acted on their assumptions according to monotheist precepts and practices that often resulted in ethnocidal and genocidal consequences. This African saying of unknown provenance succinctly sums up this tragic outcome: "Before the "white" man came, they had the Bible and we had the land. After the "white" man came, we got the Bible and they got the land." 


\section{Definition of Concepts: Eurocentrism}

The white man who invented the pencil also invented the eraser.

-African Proverb

The term Eurocentrism is a relatively recent addition to the vocabulary of anticolonialism. It denotes the "false claims made by Europeans that their society or region is, or was in the past, or always has been and always will be, superior to other societies or regions" (Blaut, 2000, p. 4). The notion of European superiority that forms and informs Eurocentrism is grounded in ethnocentrism. Ethnocentrism is the idea that one's own ethnic viewpoint or Weltanschauung (worldview) is the only one of merit, and the only lens and filter through which the customs and practices of others is understood and judged (Hammond \& Axelrod, 2006). Eurocentric thought, however, is an extreme expression of ethnocentrism in that has imposed its worldview on others through conquest, colonialism and neocolonial exploitation.

According to geographer J. M. Blaut, "four kinds of Eurocentric theory"religion, race, environment, and culture-have been used to explain how Europe managed to assert its power and control over the rest of the world's societies, their wealth, and their human and natural resources $(2000$, p. 1). Let us briefly examine each theory in the order of Blaut's presentation. (1) European Christians (like their Jewish and Muslim monotheist counterparts) claim to worship the one true god, who, through his special dispensation, guides their progress through the entire course of human history. Accordingly, their purported covenant with god and his intervention in human history on their behalf both explains and justifies European imperialism and global domination. European hegemony is thus directed and ordained by god. (2) As self-identified "white" people, Europeans claim a natural superiority over all other people in the world based on 
pseudo-scientific notions of race. Skin color and other phenotypic characteristics constitute the visible somatic markers that separate Europeans from the rest of humankind. According to the ideology of white supremacy, these biological markers signal immutable differences in intellect, morality and culture, and comprise a taxonomic system that organizes and classifies human groups in a hierarchal arrangement that places so-called "whites" on top of a human pyramid. (3) Europeans also claim the subcontinent of Europe (the homeland of god's people) is superior to other environments in its geographic location, climate and resources. Theories of environmental determinismthe belief that the physical environment rather than social conditions determines culture-date back to the ancient Greeks (B. H. Isaac, 2004) but reappear in various guises in every age. Jared M. Diamond's Pulitzer prize-winning book, Guns, Germs, and Steel, presents a recent version of environmental determinism that seeks to account for Europe's successful conquest and colonization of much of the world in the supposed "unique" climatologic and topographic features of the Eurasian continent (1997). (4) And, finally, Europeans claim the concepts of culture and civilization for themselves, the roots of which stretch back to the very beginnings of human existence (Blaut, 2000, p. 1). This Eurocentric theory of civilization brings us to a key contradiction of Eurocentrism: its dependency on "Greater Europe," the so-called Holy Land of the Middle East and North Africa, for key features of its philosophy and sciences and, most important, for its monotheist religious identity. Europe simply cannot maintain the integrity of its ideology of ethnic and cultural supremacy without cannibalizing, assimilating, and claiming for itself the achievements of other societies in nearby regions and around the world (Amin, 1989; Blaut, 1993, 2000; Dussel, 1993, 2000; Goody, 2006; Hobson, 2004; Rabasa, 
1993). Nor can it define itself without the reification and subsequent negation, denial and suppression of the other.

In defining Eurocentrism, we need to ask the questions: when, where and how did it begin? Blaut traces the beginnings of "modern Eurocentrism" to the year 1492:

When Columbus returned from his first voyage to America, he described a people who were heathens, and who, he believed, could be conquered easily. Moreover, the conquest of their land would provide gold and other wealth to Europeans. It seemed clear that Europeans were superior to these Americans and would profit from this superiority. The conquest did indeed prove fairly rapidly (mainly because the American populations were decimated by introduced Eastern Hemisphere disease), and the profits were indeed immense. Europeans could now, for the first time on a significantly large scale, make a clear distinction between themselves and a non-European people to whom they could really believe themselves to be superior. The Eurocentrism that thus emerged in the sixteenth century has two essential characteristics: superiority seemed to be confirmed by the success of colonialism; and superiority produced great profits (2000, pp. 4-5).

Blaut uses the adjective "modern" to make a subtle distinction in his argument about the origins of Eurocentrism. As pointed out above, a credible argument can be made that the concept of Christendom denotes a cognitive threshold or starting point for Eurocentrism. I would also argue here, along with Enrique Dussel, that the roots of "modern" Eurocentrism can be seen in events in medieval Iberia that set the stage for Columbus' voyage across the Atlantic (Dussel, 2000). According to this view, the basic ideological structures and taxonomies that inform the social construction of Europe as the "European Miracle"-Blaut's term that describes the Eurocentric account of the purported spiritual, intellectual and environmental superiority of the European people and their habitat - cohered in the Iberian peninsula during the latter centuries of Moorish occupation and rule. There, in Spain, the three monotheisms (Judaism, Christianity and Islam) came together in convivencia and competition to give birth to new forms of human identity and oppression founded on religious distinctions between believers and 
nonbelievers. This volatile mixture and clash of monotheisms provided the ideological context and the sociohistorical conditions for the emergence of racial slavery, the transatlantic slave trade and European imperial conquest. Columbus' voyage seen from this perspective marks the culmination of a series of events in Iberia that led to the transformation of this western-most outpost of Europe from a backwater of the EuroAfro-Asian world system to the first global European empire.

The conscious or unconscious development of those precepts of Eurocentrism that pre-date the emergence of Spain as an imperial power could be said to constitute the first phase in the evolution of Eurocentrism. This first phase established the conceptual and ideological basis for white supremacy and its use as a mechanism of social organization and stratification. The second phase, which develops primarily outside of Europe, constitutes the experimental and existential phase when the practices and tenets of Eurocentrism are tested and applied on a global stage. Jose Rabasa sees this final phase as congruent with the "invention" of America as a new world by Spanish historians during and after the conquest and subjugation of its peoples (Rabasa, 1993). This invention of America was an invention of America as Other by conquistadors, missionaries, government officials, adventurers, settler colonialists, historians and writers. The taxonomies of difference they created and disseminated-which included textual, pictorial, dramatic, and cartographic means of representation-brought together a panoply of stock motifs to depict the so-called new world and its native inhabitants as cannibalistic, exotic, passive, idolatrous, and suitable only for servitude and exploitation if not extermination. Rabasa, in his analysis of how encyclopedias and maps organized and presented these views of the Other, also shows how that process of objectification is 
linked directly to the development of the concept of the Universal Self as European. In charting these cognitive and cultural events in the Americas and Europe, Rabasa identifies the publication of Mercator's Atlas in 1595 as a significant milestone in the construction of Eurocentrism. Mercator was not the first "to organize a standard compendium of maps in a book format with a narrative supplement," but it was he who coined the term atlas after a mythical king of Mauretania" (author's italics) (Rabasa, 1993, p. 180). It is Mercator's Atlas, his compendium of maps and their accompanying commentaries that Rabasa sees as constitutive of Eurocentric thought:

As far as I know there is no history of the atlas as a genre. Insofar as such a history might turn out to be important for clarifying the question of Eurocentrism, I believe that the analysis of Mercator's Atlas is a necessary preparatory task. I also believe that the Atlas manifests the main constituents that have defined Europe as a privileged source of meaning for the rest of the world. Eurocentrism, as I will try to point out with respect to the Atlas, is more than an ideological construct that vanishes with the brush of a pen or merely disappears when Europe loses its position of dominance. The trace of European expansionism continues to exist in the bodies and minds of the rest of the world, as well as in the fantasies of the former colonizers (author's italics) (1993, p. 181).

To Mercator also goes the credit for innovating a linear form of map projection (first published as a map of the world in 1569) that results in Greenland appearing larger than Africa (Africa is thirteen times the size of Greenland) and Europe appearing larger than South America. Indeed, the entire northern hemisphere in Mercator's map projection looms larger than the southern. Rabasa compares Mercator's map with Juan De la Cosa's Portolan World Chart to illustrate "the radical shift of perspective a Mercator projection introduces into the European experience of the world" (1993, p. 189). Not only does Mercator's design privilege Europe over other geographical areas of the world, it also metaphorically expresses Europe's relationship with the rest of the world in binary terms—modern/ancient, Old World/New World, masculine/feminine, et cetera—with the 
"positive" terms accorded to Europe (Rabasa, 1993, p. 188). Thus the cartographic historicizing of the world via Mercator's map and atlas makes the world and its history meaningful only from the perspective of Europe. As Rabasa puts it: "If specific political configurations establish boundaries and national identities for a European geographic space, then the rest of the world acquires spatial meaning only after the different regions have been inscribed by European History" (1993, p. 192). This inscription of the geographic space of the world by Europeans opens its territories to European domination—spatially through conquest and colonization, and temporally through the usurpation or transmutation of all local histories as European History.

The world-remapping work of Mercator serves as one salient example of the centralization of Europe in global space and time. Economist Samir Amin, like Edward Said, cites the role of the "artificial construction of the "Orient" as "Other" by Europe as a central component of the "mythic foundation" of Eurocentrism, and views "Western history" as the product of this ideological invention (Amin, 1989, p. 89). He sees the construction of "Western history" as analogous to the Orientalist construct in that it:

... (i) removes Ancient Greece from the very milieu in which it unfolded and developed - the Orient—in order to annex Hellenism to Europe arbitrarily; (ii) retains the mark of racism, the fundamental basis on which European cultural unity was constructed; (iii) interprets Christianity, also annexed arbitrarily to Europe, as the principle factor in the maintenance of European cultural unity, conforming to an unscientific view of religious phenomena; (iv) concurrently constructs a vision of the Near East and the more distant Orients on the same racist foundation, again employing an immutable vision of religion. The four theories combined in different ways at different times. For Eurocentrism is not, properly speaking, a social theory, integrating various elements into a global and coherent vision of society and history. It is rather a prejudice that distorts social theories (italics added) (Amin, 1989, p. 90).

For Amin and the other scholars discussed above, race serves as the principle organizing force of Eurocentrism and religion provides the basis for European unity. 
With this system of taxonomy and ideology in place, Eurocentrism then manifests and operates in a variety of social ideas and behaviors in ways difficult to identify and trace. Eurocentric concepts of knowledge (epistemology) and assumptions about the universality of European values often remain hidden or masked in literature, the arts, philosophy, the social sciences, the physical sciences, and other cultural and social practices. Thus it continues as a systematic discipline and organizing force of intellectual and social relations in the so-called "postmodern" era despite recent efforts by activists and scholars to expose and deracinate it. In the chapters that follow, however, this thesis will focus primarily on how ideas and concepts of religion and race, consciously or unconsciously, operate in tandem to produce and reproduce the taxonomies of "blackness" and "whiteness," and the social contract that maintains the system of white supremacy/black inferiority. 
Definition of Concepts: "Black" liberation discourse (Afrocentrism)

If you don't know where you are going, any road will take you there.

-African Proverb

I began this intellectual journey with the intention and objective of examining and critiquing various theories of African identity, culture, and history used by prominent "black" activist-scholars in the late eighteenth and early nineteenth centuries to confront, challenge, and contest racial slavery and "white" supremacy. Given the emancipatory aims of its inventors and architects, I labeled the collective rhetorical and didactic use of these theories: "black" liberation discourses. During the late twentieth century these ideas were grouped together under the rubric: Afrocentric. Centered on modern concepts of Africa and Africanity, "black" liberation discourses or Afrocentric thought evolved from the confluence and synthesis of political and cultural nationalist ideologies developed by "free" and enslaved Africans in the West during the dehumanizing epoch of EuroAmerican slavery and the apartheid era of racial oppression that followed in its wake. Recent scholarship, however, has expanded the definition and practice of Afrocentric discourse beyond its confrontational engagement with Eurocentrism to encompass the creation and development of a body of literature and thought that delineates and disseminates a Pan African worldview. Current developments in the field notwithstanding, I embarked upon this project out of a concern that "black" liberation discourse (Afrocentric theory), in critical and fundamental ways, remains constrained and conditioned by the Euro-American sociohistorical nexus that provided its formative context and content. The spatial and temporal development of the Afrocentric paradigm within a Eurocentric worldview and its grounding in Eurocentric epistemology and methodology constituted, therefore, the principal problems that engaged my attention. 
This approach to the issues raised by the Eurocentric origins of Afrocentric discourse was premised in an important question often posed in postcolonial discourse: Can you use the master's tools to dismantle the master's house? For the purpose of this study, the master's tools are Eurocentric epistemology and the master's house is Eurocentrism. As is often the case, this central epistemological question invoked several others in its wake. Can the master's tools be used to construct counter theories of race, culture and history to contest white supremacy? Does race theory in "black" liberation discourse circumscribe and subvert the liberating intentions of its paradigm by grounding it in a conceptual fallacy that perpetuates intellectual bondage to Eurocentrism? The genealogical implications of these critical questions led to the realization that I needed to construct a solid theoretical foundation and walls before putting the roof on the house, so to speak. In other words, I realized I had to address the basic question of how "blacks" became black in the first place. Any systematic effort to identify the conceptual and cognitive origins of black liberation discourse must first contend with the formation of black identity in the African diaspora-its evolution, content and racialization. Put another way: "black" thought requires "black" thinkers.

While the main investigation of this thesis focuses on the role of the three western monotheisms in the sociohistorical and taxonomic construction of "blackness" and "whiteness," the underlying motivation for this research project continues to be driven and guided by a concern for the integrity and efficacy of black liberation discourses in the struggle against white supremacy. Since the majority of this study focuses on the negative aspects of "blackness" imposed on African people before, during and after the transatlantic slave trade, it is important here to note the positive attributes of "blackness" 
and "black" subjectivity that developed from the efforts of early "black" activists as tools of resistance. It is this tradition of resistance that informs this research project. Consequently, I included this detailed definition and analysis of black liberation discourse (African-centered thinking) in this section on theory and methodology. My purpose in doing so is to illustrate and illuminate the specific critical perspectives (and intellectual biases) I bring to this research project.

The term Afrocentrism ignites controversy whenever and wherever it appears. Molefi Asante, who claims to be a founder of modern African-centered theory and who prefers the variant Afrocentricity, offers this concise definition of the concept: "placing African ideals at the center of any analysis that involves African culture and behavior" (1998, p. 2). The definition of Afrocentrism presented below is based on the shared belief of contemporary Afrocentric scholars that modern science affirms that human history begins with African history. It also is informed by the collective efforts of "black" activist-scholars throughout history to excavate, elucidate, and document a collective human heritage that has been erased, ignored or obfuscated by Eurocentrism.

Accordingly, Afrocentrism is defined here as: a set of scientific and historical facts and theories that place the African continent and African people in the center of human development, and the systematic explication of those concepts within a philosophical and pedagogical framework designed to restore African historical consciousness and foster Pan African unity.

The ideological and philosophical roots of the Afrocentric paradigm and its related cultural and historical discourses, like most social constructions, probably extend far deeper into the past than historical records document or oral traditions iterate. A 
number of scholars have noted the obvious connections of such traditions to the transatlantic slave trade and its chaotic role in the creation of modern African diasporan identities and communities (Gomez, 1998; Holloway, 1990; Sale, 1997; Wright, 2004). Others have focused on familiar literary texts (slave narratives, poems, letters) produced by the first cohort of "black" literati in the Atlantic world as the artifactual and evidentiary instantiations of early African-centered traditions (Bruce, 2001; Carretta \& Gould, 2001; Ernest, 2004). And still others have looked to European antecedentsEnlightenment-era historians and travel writers like Vivant Denon and Count Volney, and the rites and rituals of the Masonic Lodges of England and France—as inspirations for the foundation of Afrocentric theory (Howe, 1998; Lefkowitz, 1997). Despite the contributions of these theories to our understandings of the origins of black liberation discourse, the specific genealogy of Afrocentric thought before its textual appearance in the late eighteenth century still remains a matter of much conjecture and debate. How then do we go about the complex task of recovering the intellectual prehistory of these paradigmatic ideas? This search must begin with "black" thinkers. "Black" thought requires "black" thinkers.

A number of scholars have examined the roles of "black" antebellum thinkers in the formation of Black Nationalist thought and black intellectual traditions. St. Clair Drake, Wilson J. Moses, John Ernest, and Scott Trafton, in particular, have produced definitive studies that document the origin, pedigree and social context of nineteenth century ideas and theories that formed and informed what would be described today as early African-centered approaches to African history and culture. These scholars and others also have argued that Egyptology evolved as a distinct genre of black intellectual 
discourse within its broader critique of and confrontation with Eurocentrism and scientific racism. Drake and Moses have labeled these scholarly endeavors as vindicationist and civilizationism, respectively—terms meant to describe the redemptive nature of arguments that assert the humanity and achievements of African people in the face of Euro-American claims of black genetic and cultural inferiority (Drake, 1987; Moses, 1998). But even in erudite and indispensable works such as theirs, limited attention is given to the prominence of Egyptology as a discursive tool of America's leading ideologues of white supremacy and racial slavery. Even Martin Bernal in Black Athena, his voluminous writings on the de-Africanization of Ancient Egypt, overlooks or omits the singular role of American ethnologists in the formation of scientific racism and the Aryan model of ancient civilization (as he has dubbed it) (1987). Trafton's book, Egypt Land: Race and Nineteenth Century American Egyptomania, has been a muchneeded addition to this area of antebellum studies. Trafton documents Egyptology's role in the nineteenth century in providing crucial if not credible support for the anthropological schema and theories of prominent American scholars such as Samuel Morton, Josiah Nott and George Glidden, and their advocacy of the polygenetic theory of human development—a doctrine that purported to demonstrate the separate evolution of human populations based on presumed racial and cultural differences (Trafton, 2004). Polygenetic doctrine combined biological theories of hybridity (fanciful notions that the offspring of "blacks" and "whites" were infertile) with the belief that "blacks" were culturally inferior (the Hegelian assertion that "blacks" produced no history or civilization) to proclaim that Africans constituted a separate and inherently inferior species. The merger of biological studies of human crania and anatomy, which purported 
to describe the distinct physical differences between "blacks" and "whites" with cultural theories that appropriated Ancient Egyptian mummies, monumental architecture and portraiture as evidence of Caucasian superiority from antiquity to modernity, produced what Robert J. C. Young has referred to as "an indistinguishably scientific and cultural theory of race" (Young, 1995, p. 124). The slaveocracy ethos of nineteenth century America provided the social and intellectual laboratory wherein biology and Egyptology were catalyzed to produce this lethal proslavery concoction. Polygenetic theory provided the formula whereby Africans were excluded in theory from the concept of the human family as they had been in practice from the Enlightenment-inspired assertion in the U.S. Declaration of Independence that "all men are created equal."

This new form of scientific racism appeared at the precise historical moment the premises and presumed benefits of racial slavery were undergoing a massive ideological and juridical assault by abolitionist forces in Europe and America. The increased numbers, visibility and social activism of free "blacks"- actuated and encouraged by the abolition of slavery in the Northern states in the late eighteenth and early nineteenth centuries-drove white supremacists to seek new arguments to support and maintain the slaveocratic system. These theorists agreed with Thomas Jefferson, the founder of American scientific racism, that free "blacks" had no place in white America. Beneath the rhetorical veneer of its proslavery arguments however-and with the exception of the polygenetic thesis - scientific racism differed little in its assumptions and conclusions from other ideologies that occupied key and prior positions in the proslavery debate. The paramount source among these was western monotheism. The trans-Atlantic slave trade began with the official sanction of the Catholic Church. Permission for enslaving 
Africans was granted in the form of a Papal Bull (decree) that authorized slaving expeditions to be conducted as a "crusade" against "infidels" (Blackburn, 1997a, p. 103). Christianity and Christian beliefs (such as those based on medieval-era interpretations of the Biblical curse of Ham) offered supernatural explanations and divine justification for African enslavement and exploitation (Braude, 1997; Sweet, 1997). Religious bigotry in the form of Christian doctrine that anathematized non-believers aided in the expansion of the transatlantic slave trade in the sixteenth century, and provided an ideological framework for the juridical acts that authorized the racialization of slavery in the seventeenth century. The century that followed produced some of the earliest and most influential "black" writers in the English language. Christianity, with its emphasis on biblical literacy, facilitated the emergence of these "black" literati while at the same time Christian indoctrination circumscribed, muted or subverted their literary voices and messages of protest. The inventors of black Atlantic literature, however, perhaps fully aware of the irony of voicing "blackness" in a white language, used and adapted various literary forms (poetry, captivity narratives, autobiography) to debate and counter the theological bigotry and racism of Euro-America. Phillis Wheatley, Olaudah Equiano, and Ottabah Cugoano, among others, addressed in their own ways and entirely independent of the traditions of black protest that later followed, the questions of African humanity and spirituality, and the rights of "blacks" everywhere to be free (Bruce, 2001; Carretta \& Gould, 2001).

Secular worldviews that both preceded and accompanied the rise of Western science, and that systematically threatened the traditional authority of Christianity in every sphere of Euro-American life, also came into prominence during the Enlightenment 
era of the eighteenth century (Porter, 2000). The secularization of Western thinking and thought engendered a modern epistemology for the modern Eurocentrism that emerged with the expansion of European imperial and economic power. Much of this thinkinggrounded in the ideology of natural philosophy_-became highly influential in the revolutionary rhetoric that flowed back and forth across the Atlantic and that led to the radical political transformation of the Atlantic world (Diggins, 1976; Eze, 1997). Paramount among these concepts was the idea that human cultures and civilizations progressed in a linear fashion through various stages from savagery to enlightenment. This theory of social progress emphasized the role of the environment and nature in the formation, organization and advancement of human cultures, and served as a fertile source of speculation about the differences between European and non-European societies (Hannaford, 1996). Influenced by these ideas and responding to their use in proslavery arguments, "black" intellectuals in the early decades of the nineteenth century took their first rhetorical steps toward the development of the Afrocentric paradigm (Moses, 1998). They appropriated Eurocentric theories of progress and civilization and developed from them a series of eloquent and often erudite arguments about the antiquity of African civilization and its progressive social and scientific influences on the ancient Mediterranean world. This civilization debate — which remained deeply rooted in Eurocentric notions of human progress and history despite its deconstruction by "black" scholars-became a complex staple of black protest rhetoric of the era (Moses, 1998). Thus when "whites" insisted Africans were innately deficient in morals or intellect and incapable of civilization or the civilized behavior necessary to participate as free citizens in America, R. B. Lewis, Hosea Easton, Peter Randolph, David Nickens and other 
"black" social and religious leaders immediately countered from lecterns, from pulpits, and in print with specific examples of African cultural genius (Rael, 2002). Vindicationist and race redemptive concerns drove the design and intent of these "black" protestations, and directed them as much to the attention of Northern "white" audiences as to that of the free "black" literate elite. Yet these arguments often included percipient and profoundly apposite approaches to the increasingly intractable problems of defining and achieving freedom, justice and equality in a nation that had divided its self into putatively free and de facto slave states.

Just as the development of scientific racism accompanied the rise of abolitionist attacks on the slave trade and slavery, the appropriation and use of Egyptology by "black" scholar-activists proceeded from their critical need to defend the humanity of African people from new and increasingly genocidal onslaughts by Euro-American intellectuals. The earliest published references to Ancient Egypt by "black" intellectuals marshaled biblical, classical, and contemporary European sources in support of arguments designed to elevate or vindicate the character and identity of African people within the standard framework of the civilization debate (Moses, 1998). The first black newspaper Freedom's Journal demonstrated this paradigmatic discursive practice in a column published the year of its founding (1827). Titled Mutability of Human Affairs, the article conveyed in abbreviated form both an explication of Ancient Egypt's founding by "blacks" and a dissertation on the inevitable fall of great civilizations (Bacon, 2003). In a brief and rambling exposition, it articulated the principle arguments that have remained central to Afrocentric thought since its inception. This example and numerous others from the early decades of the century demonstrate that "black" scholars had developed a 
unique appreciation for the discursive value of Egypt, and recognized its growing importance and strategic position as ideologically contested terrain in the intellectual war against white supremacy. Thus when Egyptology emerged as a mainstay of racist anthropological theories in the 1850s, "black" intellectuals quickly responded to the pseudo-scientific assaults and insults of American ethnographers. In an explosive speech delivered in Cleveland, Ohio in 1854, Frederick Douglass entered the debate with a mockingly ironic rebuttal: "But Egypt is in Africa" (1854, p. 288). With this simple yet dramatic declaration of geographical orientation, Douglass and other "black" thinkers strategically redeployed an old argument against a new threat, and moved black liberation discourse into a new era of scientific debate.

Despite the Herculean efforts of Eurocentrists to de-Africanize it, Egypt remains in Africa. Early "black" activists seized on this geohistorical fact and organized and expanded it into a discourse that both asserted and defended the African origin of Egyptian civilization. In speeches, pamphlets and newspapers, "black" intellectuals depicted and extolled an Ancient Egypt that embodied and exemplified the very notions of African humanity and intellectual achievement that white supremacists claimed were historically impossible (Ernest, 2004; Trafton, 2004). The Eurocentric trope of white supremacy and polygenetic doctrine thus came under immediate attack from the Afrocentric trope of "black" humanity and its new theoretical approach to the study of African identity and culture. By these mean "black" scholars linked the history and culture of Africans in America to Ancient Egypt much in the same manner German Romanticists linked Northern Europe to the Mediterranean civilizations of ancient Greece and Rome (Bernal, 1987; Dussel, 2000). With these reactionary and self-defensive 
measures, antebellum "black" thinkers established the potentially proactive paradigm from which Afrocentric thought and discourse has developed over the course of nearly two centuries.

In applying this particular prismatic lens- the view of Africa and Africans through the fractious sociohistorical constructions of "black" and "“"white"” American intellectuals of the antebellum era-I have emphasized the centrality of Egyptology to Euro-American racist ideologies and African-American redemptive strategies in an effort to illuminate the dialectical power struggle convened and articulated between the oppressed and their oppressors over the founding modern illusion of human identity: race. Black liberation discourse came into prominence in the nineteenth century to challenge Eurocentric constructions of race. It succeeded in implanting in the minds of literate free "blacks" in the antebellum North the importance of African history in the black liberation struggle. Yet its founders were unable to perceive or avoid the contradictions and ironies inherent in using Eurocentric concepts of history, culture and civilization to combat white supremacy and scientific racism. Thus, from its inception, the smoke and mirrors of racial ideology infiltrated and compromised the radical and revolutionary intentions of Afrocentric discourse, and the liberationist narratives articulated by its founders and proponents.

The problem of racial ideology in the theoretical assumptions and presuppositions of early "black" intellectuals has received wide and prominent treatment in recent studies (Appiah, 1992; Drake, 1987; Howe, 1998; Lefkowitz, 1997; Moses, 1998; Shavit, 2001). Such studies however have produced mixed results. Some critics, from the privilege of hindsight, have found it simply more expedient to accuse the early proponents of 
Afrocentric thought of racialist and essentialist proselytizing, rather than view their discursive strategies against the background of their life-or-death struggles for their humanity. "Black" activists of the antebellum era-whether they were born free or stole themselves to be free, whether they resided in the nominally free north or the intransigently slave south, whether they were churched or unchurched, lettered or unlettered-lived in a world circumscribed by the one drop rule and the fictive taint of "blackness." "Whiteness," a pigment of the Euro-American imagination, was both the prerequisite and privilege of citizenship. It is neither hyperbole nor cant to claim therefore that racism exemplified the American experience or that Africans, as exemplars of race in the Eurocentric mind, were the principle targets of its social and political violence. Within this pathologically race obsessed environment the "black" pioneers of early liberation scholarship constructed their own theories of African identity, culture and history as tools of survival and weapons of resistance. From their lived experiences of racism, and from the racial concepts that defined and circumscribed their lives, they reconstructed and redeployed race for the sole purpose of self-defense.

The failure of some scholars to contextualize the struggle of Africans in America for self-definition and self-preservation has produced unfair analyses and characterizations of their motives and marked them as victims rather than beneficiaries of their seminal intellectual achievements. This is not only a problem of presentism in the study of black intellectual history; it is also a failure to acknowledge and address the existential reality of antiblack racism. The advent of critical race theory and the propagation of arguments from ebony and ivory towers that race is a biological fiction or sociohistorical construction have not eliminated racism or its lived experience from the 
American landscape any more than did the abolition of the slaveocracy system which was the root cause of its existence. It can be argued in fact that emancipation exacerbated the tendencies toward antiblack racism, and fostered the establishment of antiblack policies as the means to maintain social and economic control over "black" people. Lynching, "white" mob violence, and the proliferation of Jim Crow apartheid laws enacted in the wake of the passage of the $13^{\text {th }}$ Amendment codified and enforced the brutal reality that free "blacks" were an anathema to Euro-American society and a crime against white supremacy. Therefore, it is only within the contexts of the existential reality of racism that the use of racial or essentialist concepts by early "black" scholars can be fully comprehended.

Despite much of the current literature's focus on Afrocentric historiography, it is my contention that the best way to comprehend and critique African-centered thought is through a detailed examination of its rhetorical applications and discursive practices. Current scholarly preoccupation with the historical content of Afrocentric discourse problematizes its study and analysis by obscuring its role and purpose in the African liberation struggle. For example, the widely reported arguments from critics opposing the claims of some Afrocentrists that Cleopatra VII was "black" have been framed in historical debates that miss or ignore the larger importance of Afrocentric discourse in challenging the hegemony of pseudo-universal notions of whiteness. If the concept of race has no scientific basis or validity, any proposed answer to the frequently cited Cleopatra question or similar problems is valid or relevant only within the context of intellectual and ideological warfare over sociohistorical constructions of race and who has the power to form and inform them. Recognizing that the context of Afrocentric 
thought—its specific orientation to and relation with Eurocentrism—often receives cursory or limited treatment in the existing literature, I shifted the critical analysis of the subject from the current focus on its historiographic methods and outcomes to its ongoing dialectical engagement with white supremacy.

Scholarly and popular denunciations of Afrocentric thought as Afrotopianism, essentialism and historical fabrication, based mainly and not always accurately on criticisms and analyses of its use of racial theories or methods, deflect attention from the landmark achievements of "black" intellectuals in deconstructing and contesting Eurocentrism and decolonizing black studies. "Black" activist-scholars were among the first non-Europeans to challenge in practice and in print the ideology of white supremacy in all its complex social, political and economic manifestations and permutations. The interstitial space opened up by their resistance to European power and dominance created the ideological locus and intellectual opportunity for the emergence and articulation of non-racialist liberation discourses. Unlike Eurocentrists and white supremacists who promulgated and promoted discourses of racial difference and inequality to maintain the hegemony, status and privilege of "whiteness," the architects of the Afrocentric idea-in their preoccupation with African cultural identity and ancient African civilization—did not preach the hegemony of "blackness"; instead, they were among the most vocal advocates of universal humanism and the monogenetic origins of the human species.

The view of black liberation discourse articulated here starts from the position that its theories and methods originated and functioned in its nascent phase not as a school of history but as a critique of history that cohered within the socio-political struggle against the hegemony of "whiteness" and its physical and ideological 
subjugation of non-whites. In tracing the trajectory of the Afrocentric idea, it is apparent that a critical distinction needs to be made between its early deconstructive role as a selfdefensive critique of Eurocentrism and its later performative role as a counternarrative with the explicative power to construct new forms of "black" subjectivity. Investigating this subtle shift in rhetorical and discursive practice reveals how Afrocentric engagement with Eurocentric history as an object of interrogation results in its self-referential use of history and the eventual production of its own forms of historicizing. It also further substantiates how Afrocentrism's encounter with and response to antiblack racism fosters a type of vindicationist historicism, which in turn makes it the subject of a particular kind of reactionary and knee-jerk historical analysis that can and often has obscured and distorted its original hermeneutic mission and semiotic purpose.

This analytical definition of Afrocentric discourse is open to criticisms of reductionism from both sides of the debate. In an intellectual environment where both its proponents and opponents tend to expand the definition and practice of Afrocentric thought beyond its original analytical and critical premises and functions, such objections are expected. Thus Afrocentric discourse is either celebrated or denounced for becoming a mirror image of the thing it was conceived to deconstruct. Like any other discipline, there is much to criticize in Afrocentric thought. However, I maintain that it is an error in logic to apply current definitions and standards to the early theory and practice of black liberation discourse. David Hackett Fischer has identified this type of analytical flaw as a genetic fallacy: a failure to distinguish between the becoming of a thing and the thing it has become (Fischer, 1970). In this case, arguments designed to foster black unity in the struggle against slavery and antiblack racism have become a set of historical narratives 
and theories about African identity and the role of Africans and Africa in human development and history. The two things are not the same, although it is easy to see how they are apt to become confused and conflated.

In defining early Afrocentric thought as a type of strategic essentialism for selfdefense and self-preservation actuated by the existential reality of antiblack racism, I have attempted to reconstruct the cognitive path followed by early "black" activistscholars who took the "blackness" that "white" ideologues and oppressors invented and imposed on them and turned it into a weapon of liberation. Despite the prevailing nineteenth century Hegelian view that portrays Africans as lacking historical agency, their presence and struggle for survival in the Atlantic world helped to make and remake the history of modern Euro-America and modern Africa. Joseph Roach (1996), Paul Gilroy (1993) and others have argued that diasporan "blacks" were central to the development of modernity as both subjects and actors in its enactment and evolution. In the fight for freedom and identity in the world they helped to create, "black" people reconstructed and redeployed Western languages, literature, philosophy and science to express the values, ethics and ethos of "black" subjectivity and resistance. The diasporic African confrontation with and contribution to the West occurred during the rise of Eurocentrism and at the precise moment Europe's pseudo-universal history (Bernal's Aryan Model) was concocted, reified and disseminated to the peoples and nations it had conquered and subjugated. The clash and conflict of worldviews was immediate. As Eurocentrists sought to control the present and reinvent the future by colonizing the past with the modern myths of science and the ancient myths of the Bible, Afrocentrists responded using their own Sankofian strategy to reach back and bring forward an 
African-centered view of humanity and human existence before the advent of the genocidal transatlantic slave trade, and before the presumed existence of Europe as a geohistorical construct. Their rhetorical appropriation and discursive use of Egyptology constituted the first ideological assault on the infrastructure of Eurocentrism from an "other-centered" perspective. With the dissemination of these radical and revolutionary ideas in print and public forums, "black" activists set about the monumental task of dismantling the master's house. This research study follows and builds upon the precepts and principles of those black liberation discourses founded two centuries ago. 


\section{Theoretical Problems: Trans-history/meta-theory}

The truth that was lost in the morning often comes home in the evening.

-African Proverb

The sections that follow discuss general theoretical problems and issues in historiography with particular attention given to the European conception of modern history and its ideological use by the West. Although the current vigorous debates about the relation of theory to history are not central to this thesis, the nature of the problems involved has important implications for the critique and analysis of Eurocentric and Afrocentric thought (black liberation discourse) herein proposed. Consequently, I think it is germane to discuss the theoretical and philosophical frameworks used to contrast and compare the rhetorical and discursive practices of African-centered though with the Eurocentric theories and structures of knowledge from which they emerged, and to view these two systems of thought against the larger problems of structuring and constituting knowledge and history in general. To achieve this expository goal I have imposed another frame of analysis within the larger frame of the basic critical theory approach of this study. This smaller frame or lens invites into this discussion forms of poststructuralist analysis that allow for the interplay of multiple voices and multiple perspectives to emerge within a given expository and interpretive context. This concern with multivocality recognizes the global nature of Eurocentrism and its contestation from multiple sites of resistance in the form of "subjugated knowledges"- a term used by Foucault to link together those philosophical movements critical of the dominant Western episteme (Foucault et al., 2003, p. 7). It also recognizes and addresses the often less visible structures of oppression that exist within Afrocentric and other discourses of the oppressed. This study investigates these larger conceptual and structural problems within 
the framework of its critique of Afrocentric theory, at the same time it goes beyond that critique to identify pluralistic and global solutions to the paramount issue of dismantling the master's house. Such solutions and the liberation discourses they articulate arise from multiple sites of resistance, i.e., from feminist theories, Latino/Latina studies, Asian Studies, certain sectors in Euro-American academe, Africana philosophy, Pan Africanism, and other diverse sources. The basic idea that underscores this methodology is that these theoretical approaches can be universally empowering and liberating if conceptually and pragmatically grounded in the global nature of the problem of Eurocentrism and not the local nature of a particular perspective.

My search for a critical perspective and framework to investigate Eurocentrism and black liberation discourse followed a path informed by Samuel Weber's cautionary dictum: "a social historical critique which does not consider the conflictual structure of its own discursive operations will only reproduce the constraints it is seeking to displace" (cited in Young, 1990, p. 129). Weber's statement made me more critically conscious of the philosophical baggage I brought to this study as a researcher. Equally important, it guided me in formulating and stating a fundamental problem in Afrocentric theory, as I perceive it, as follows: the essentialist premises of Afrocentrist discourse reproduce the conceptual fallacies and constraints it seeks to dismantle in its critique of Eurocentrism.

The protracted struggle against white supremacy has focused "black" thought mostly on defining Afrocentric theory and locating its ideas in categories that purportedly oppose and resist Western ideology and dominance. The Afrocentric paradigm conceived from this process may be centered on Africa, but it has remained nonetheless conceptually grounded in Eurocentrism. The basis for this assertion is twofold. First, 
when it appropriates and uses essentialist and historicist concepts to challenge and contest the hegemonic discourse of white supremacy, Afrocentric theory functions in theory and practice as a Eurocentric critique of Eurocentrism. Second, the purported "center" of African-centered thought - the theoretical template some Afrocentrists have used to construct "black" identity and reconstruct "black" history—relies extensively on representations of Africa and Africanity invented by Eurocentrists to enact and actuate European colonial power and epistemological dominance. It is this Africa of European imagination that was re-imagined in the late eighteenth and early nineteenth centuries by pioneering "black" intellectuals in their efforts to combat the black inferiority/white supremacy discourse that was both the pretext and context of the transatlantic slave trade and the racialization of slavery in the Americas. The liberationist intent of the vanguard cohort of antebellum "black" intellectuals who constructed Afrocentric discourse goes unquestioned in this analysis. Theirs was a strategic response to racism and white oppression at a historic moment when nine out of ten "blacks" in America were enslaved. The grounding of their discourse in the ontological/epistemological confusion of Eurocentric historiography, however, poses important problems for this study and for any effort to investigate the successes and failures of black liberation discourses in dismantling the master's house: that is, in deconstructing and deracinating white supremacy and resisting the subversion and violence of the Eurocentric episteme that inscribes and reifies it. Hence, I have found it useful and productive to apply the same criticisms to Afrocentrism that Afrocentrism applies to Eurocentrism. This method helps to uncover the structural problems in Afrocentric discourse suggested by Samuel Weber's axiom cited above. It also enables me to locate the overall critical perspective of this 
thesis in the kind of "border thinking" Walter Mignolo refers to in his study of coloniality and subaltern knowledges: Local Histories/Global Designs (2000).

Mignolo posits border thinking as a method to decolonize knowledge and expand it beyond its Western conceptualization and understanding. He cites Abdelkebir Khatibi's concepts of "double critique" and "other thinking," and Valentin Mudimbe's idea of "African gnosis" as integral to his formulation of this strategy (Mignolo, 2000, p. 6). Conceived as a site of resistance to the domination of the Western episteme, border thinking categorically rejects the idea that knowledges produced from non-European cultural perspectives are invalid and unscientific, and that the West alone produces science and is therefore unique in its capacity to know and understand "other" cultures.

The term border gnosis, as proposed by Mignolo, denotes knowledges "conceived at the conflictive intersection of the knowledge produced from the perspective of modern colonialisms (rhetoric, philosophy, science) and knowledge produced from the perspective of colonial modernities in Asia, Africa, and the Americas/Caribbean" (2000, p. 11). The Afrocentric paradigm roughly fits within the category of border gnosis: it was conceived from the perspective of colonial modernities in the Americas, and the border gnosis or knowledge it articulates developed out of the conflictive experiences of the colonized and includes knowledges of the pre-colonial past. However, its evolution within the margins of the modern world system has resulted in its opposition to colonialism often being expressed in ideas, terms and perspectives deeply influenced or subverted by colonialism. This situation complicates efforts to resist the domination of the Western episteme and avoid the vexing problem of conceiving and convening liberation discourses that remain complicit with various forms or categories of 
oppression. Mignolo offers Khatibi's idea of a double critique as a way out of this dilemma. Citing Khatibi's research on Islam's confrontation with the West, Mignolo argues that a double critique provides a unique locus at the intersection of knowledges produced from two fundamentally opposed historical traditions. This locus offers an independent site from which to analyze and evaluate such knowledges and their sources. Critical analysis of one tradition from the perspective of an "other" tradition implies that one thinks from both traditions. A double critique enables one to think from both traditions "and, at the same time, from neither of them" (Mignolo, 2000, p. 67). Specifically, a double critique becomes a way to overcome the territorial definitions and limitations of knowledge imposed, for example, by Afro- and Euro- centrisms, and to confront those different conceptions of history at the intersection of their confrontation with each other and within the context of their power relations. Mignolo offers this complex yet lucid explanation of how border thinking works with double critique to release and produce alternative knowledges (gnosis) and new forms of liberationist thought:

This border thinking and double critique are necessary conditions for "an other thinking," a thinking that is no longer conceivable in Hegelian dialectics, but located at the border of coloniality of power in the modern world system. Why? Because Hegel's dialectics presuppose a linear conception of historical development, whereas "an other thinking" is based on the spatial confrontations between different concepts of history [...] The epistemological potential of border thinking, of "an other thinking," has the possibility of overcoming the limitation of territorial thinking (e.g., the monotropic epistemology of modernity), whose victory was possible because of its power in the subalternization of knowledge located outside the parameters of modern conceptions of reason and rationality. A double critique releases knowledges that have been subalternized, and the release of those knowledges makes possible "an other thinking" (2000, p. 67).

The Afrocentric paradigm emerged at the intersections of the colonizers' forms of knowledge (Eurocentric historicism) and the subalternized or marginalized forms of 
knowledge of the colonized and enslaved (local and oral traditions). This juncture produced a disjuncture within which the rhetoric of modern history, philosophy and science (Western epistemology) became the means to express the narratives and knowledges of slavery and colonialism from a colonized or Pan African perspective. From the margins of American society, the pioneer thinkers of African-centered thought conceived "an other thinking" or alternative narrative of modernity and released that narrative within the contested space of the Euro-American ethos to make possible "an other thinking" about the nature and meaning of human freedom and, indeed, humanity itself. Thinking on the border they tried to shift the center of the debate about "black" identity and history from the dehumanizing ethos of their enslaved present to an imagined pre-colonial past, a past before European hegemony. In going back to the past they saw themselves moving forward to a future of freedom and equality. Going back to the future, in this specific instance, constitutes a Sankofian movement to rupture "the monotropic epistemology of modernity" and break with Hegelian dialectics and the linear conception of history described by Mignolo above. The lack of a double critique, however, resulted in "black" intellectuals re-conceptualizing the past with essentialist fallacies of presentism born out of the contemporary nature of their racial predicament. Thus "racial rhetoric" became an integral part of their "other thinking" and compromised its "otherness."

Border thinking mediates between the ideology of the oppressors and the pedagogy of the oppressed in the interstitial zone where the existential contests between local histories and global History are enacted and played out. It offers a locus of analysis and enunciation that identifies and addresses the subaltern nature of black liberation 
discourse as a counter-narrative of modernity, while it also distinguishes the ways in which modernist/colonialist modes of thinking are implicated in Afrocentric thought. It provides a means to see Afrocentric discourse as inseparable from the modern world system it deconstructs, while accepting the gnosis or knowledge produced by the Afrocentric critique as a cognitive step on the path toward a trans-historical and metatheoretical liberation discourse that can fully and effectively resist the global tyrannies of sexism, racism, and capitalism.

\section{History, Centrisms and the Desert of the Real}

The measurement of the opinion and deeds of the past by these universal opinions of the present is called "objectivity" by these simple people. They find the canon of all truth here: their work is to adapt the past to the present triviality and they call all historical writing "subjective" that does not regard these popular opinions as canonical. (Nietzsche, 1957)

In Discourse on Colonialism, renowned Caribbean writer Aimé Cesairé argues that all history is "white," European and male (Cesairé, 1972). Referencing the texts of prominent French intellectuals (Ernest Renan, Roger Caillois, and Arthur Gobineau), Cesairé identifies and indicts the ethnocentric, geographic and gender bias of modern historiography and its ideological use as a tool of European hegemonic discourse.

Cesairé's anticolonial discourse and the Afrocentric critique both seek to expose the contradictions between the Eurocentric claim that European historiography constitutes and produces a universal History, and the reality of its genuinely parochial mode of production and ethnocentric products. Anticolonial and Afrocentric discourses contest the Eurocentric assertion that the local histories of the world are conceivable only as moments, repetitions, variations or validations of the History of Europe. Afrocentric discourse, particularly in the latter half of the twentieth century, has attempted to 
intervene in the unicentric and monopolistic production of history through the production of its own narratives or counternarratives of modernity (and antiquity). This intervention has occurred in three stages. In the first stage, this liberation discourse operates as a form of resistance to the European appropriation and incorporation of the Other (nonEuropean) into European History by contesting the marginalizing, silencing and denial of the historical agency of the Other through its general critique of Eurocentric historiography. In the second stage, Afrocentrists convene various projects to rewrite African history from a purportedly African perspective. In the third stage, the (re)inscription of African history (re)inscribes European history, and, by inference and implication, the history of the modern world. These writing, over-writing and rewriting agenda of de- and re- centering equally reveal and conceal, describe and disguise, remember and erase the past as prologue and the past as present.

The critical theory perspective of this research project views all forms of historiography as embodying various fallacies of presentism or anachronism. Afrocentric historicism, particularly in its use of essentialist or racial concepts, does not escape these problems. Yet the perspectivist approach of Afrocentric discourse-its form of border thinking-illuminates with stark contrast and sharp relief the ideological boundaries, differences and conflicts between the "center" of Euro-American discourse and the shifting "center" of non-European historicizing. The Afrocentric aim of decolonizing the past challenges the traditional epistemic foundations of historiography, its general organization and presentation in the form of the tripartite division of ancient $/$ medieval/modern, and how various eras and epochs of human endeavor within those divisions are categorized and defined. Below, I will briefly examine how the status 
quo of historical periodizing is ruptured by this critique. Here, I want to point out why the rupture is only partial and thus does not effectively dismantle the system in its entirety. The Afrocentrist critique falls short in deconstructing the theories of historical change that constitute Eurocentric historiography for two basic reasons. First, it consciously and unconsciously accepts and incorporates Eurocentric positivist and mechanistic explanations of historical processes into its discursive theory and practice. Second, rather than limiting its critique to the deconstruction and dismantling of Eurocentric history, it posits and constructs its own global history with its own set of universalizing premises as an alternative world system model. Because the two centrist systems of thought operate from commensurable epistemological premises and principles, Afrocentrism cannot effectively erase Eurocentrism without erasing itself. With Afrocentrism functioning more or less as a Eurocentric critique of Eurocentrism, its discursive efforts to de-center Europe and overcome the socio-political dominance and violence of its episteme are compromised and subverted from within.

De-centering Europe breaks the hold of the Eurocentric matrix or virtual reality on the consciousness of its objectified and colonized subjects. But what are the theoretical implications of re-centering in a non-European locus? Rather than producing a genuine paradigm shift or the accession of an authentic historical consciousness, as some Afrocentrists believe, I would argue that the resulting epiphany could be described instead as the immersion of the colonized subject's consciousness into yet another functional incoherence. Although an admittedly vague term, functional incoherence provides a useful label for the false ontology that instantiates and sustains centrist ideology. The incoherence of the centrist premise and its "we are the world" philosophy 
is evident in its conversion and expansion of a single culture (i.e. Europe/European) into a statement of Universal Culture. To establish and maintain the autonomy and supremacy of its idealistic creation, centrist discourse then negates the existence, historicity, or validity of other cultures. Supremacy, or hegemony, however, does not equal universality. Nor does the act of negation erase the Other as much as it affirms the existence of the Other by its attempt at erasure. So despite its functional successes as an organizing principle of social perspective, belief and action, centrist ideology remains inherently illogical, incongruent and inconsistent, hence, incoherent.

For Pan African scholars in and outside the Afrocentric School, the centrist issue raises important questions that challenge the current use of history as a discourse in the struggle against white supremacy. If in fact all history is "white," European and male (i.e. produced within a European conceptual framework), then there is no history outside of History to retrieve. Seen in this light, the rewriting of African history from an African perspective becomes an exercise in tautology and circumlocution. What is rewritten becomes visible only through the same Eurocentric lens that privileges the idea of History and that refuses the narratives of the Other or other narratives. As Robert Young points out: "For the other to remain other it must not derive its meaning from History but must instead have a separate time which differs from historical time" (emphasis added) (1990, p. 15). Hence the shift from one centrism to another does not avoid the problems of Eurocentric historiography it merely duplicates or reproduces the ontological errors of Historical time within another socio-intellectual site. The centrist shift also reveals the fallacy of centrist thinking in general, with the logical result or outcome of this process being: things fall apart, the center cannot hold. 
The center cannot hold because it exists only as a virtual reality, a smoke and mirrors concoction created from culturalist and materialist projects that define historical reality and verisimilitude according to social constructions of gender, race, geography and time. Once identified or established, such a center becomes yet another cognitive domain mapped and marked by patterns and practices of inclusion and exclusion that signify and denote notions of internal and external differences, and that condition and restrict human interactions and freedom. The geo-historical construction of Africa in contemporary discourses provides an instructive case in point. Regardless of the name we use to identify the immense continent in the center of the planet, which some say resembles a giant question mark, or how we classify its diverse human occupants with their complex societies, unquestionably, the place and the people who inhabit it are physically there. But when it comes to the question of locating and defining an authentic African identity or type, like Gertrude Stein once said about Oakland, California: "there is no there there" (Stein, 1971, p. 289). This statement does not deny the existential reality of African people or the relevance and specificity of their social actions and interactions. Instead it argues against the totalizing and homogenizing of African existence and experience. Whether Euro- or Afro- centric, such discursive strategies result in reductive rather than inductive analyses of human diversity and individuality and perpetuate the fallacies of essentialist differences by converting imagined ethnic archetypes and stereotypes into the virtual human phenotypes upon which History mediates and operates. Against the constantly shifting fields of time and space, and the changing patterns of human interactions with each other and their environments, the 
phenotypic standard remains fixed and unchanging, invariably European or Other in its historically constructed identity, subjectivity and consciousness.

The honest efforts and important contributions of well-intentioned "black" scholar-activists notwithstanding, historicizing Africa from an African perspective does not correct the problem of Africans being left out of History; it merely reinforces the specious claim that History, as currently defined and practiced, provides the only means to fairly and accurately represent the human experience in and through time. Addressing the specificities of the African experience (or indeed any local or regional experience) and integrating that experience into a global framework or narrative requires us to identify how human societies are interrelated beyond the illogic of centrisms, and the sociohistorical constructions of race, class and gender. Thus what is determined to be local or universal in the human experience is not projected outward from a central ideological site or conception of time or geography, but arises from multiple experiential and cognitive sites and traditions.

The conceptual vacuum that exists (or non-exists) in the absence (or transparency) of sociohistorical constructions constitutes the groundless ground of reality that the center cannot hold. This is a rather Zen-like argument that what constitutes reality is, in reality, an unconditioned, groundless ground without boundaries, meaning or direction. But just as it is said that nature abhors a vacuum, human consciousness has set up shop in the void of reality and colonized it with the imaginary. The term "imaginary" as used here should not be taken to imply that what is imagined as reality does not have real consequences; on the contrary, race, a purely imagined concept of modernity, functions (or dysfunctions to be precise) as a definitive and constant force in determining global human relations. 
Gender, and the inequities and violence it engenders, constitutes another virtual reality of modern society. The simulated nature of "modern" reality implied in this discussion (and by philosopher Slavoj Zizek's notion of the "desert of the real" popularized in the Wachowski brothers' film The Matrix), suggests that our passage across the horizon of human history unfolds from an imaginary past to an imaginary future (Zizek, 2002). Rather than deny the reality of the human journey through time and space, however, this statement refuses the totalized logic of that experience as articulated in linear and causal explanations of historical change and progress. How the human journey unfolds as history, and how it is described as History unfolding, is not the same thing.

In the modern world system History serves to make the past intelligible, tangible, meaningful and manageable. It replaces the old mythic cycles of time and the mythological mysteries of human existence with a linear conceptualization of time as a progressive and teleological force that reveals the meaning of human history through its expression and fulfillment in the emergence and domination of the West. Time is both the currency and the commodity of this ideology. It is the argument for Western superiority and its proof. Yet for all the struggles of humanity to perfect, divide and structure systems of measurement and theories of change into calendars and historical periods no one currently knows what time it is. The fundamental question of historical orientation (what time is it?) is answerable only in reference to whose time it is. Whose time is it? The Christian calendar tells us it is the year 2007. But it is 6241 according to the first Egyptian calendar, 5765 in the Jewish calendar, 2549 in the Buddhist calendar, and 1425 in the Muslim calendar (Duncan, 1998). Thus historical time functions as an ideological matrix, a system of belief and faith structured and organized to maintain and preserve the 
cult in power and the power of the cult. Since the advent of the so-called modern world, the cult in power has been Eurocentric and its power has been white supremacy.

Like the panoramas in anthropology books that purportedly illustrate human evolution from an ape-like ancestral specimen in Africa along an unbroken line to its apotheosis as a "white" man in Europe, the inexorable march of History is a trick of the mind's eye, a mirage in the desert of the real, a solipsistic self-deception similar to the optical illusion of the sun rising and setting on the earth's horizons. Human beings conduct their lives with this social illusion in the foreground and the material reality in the background. With the earth's movement mistakenly perceived as the movement of the sun, we spend our days (and nights) in a state of functional incoherence convinced we are headed straight to the future while going around in circles. Functional incoherence also describes the state or condition in which modern History operates. As a totalizing scientific account of human events, History functions as a coherent statement of the incoherence of the human experience in time. It posits Europe as the nexus where History begins and ends (the horizons where the sun rises and sets), and thus makes time the servant of European ideology and socio-economic power. It convenes its narrativeswhich do not conform to reality but to what reality is imagined to be-using pseudoscientific arguments steeped in the rhetoric of rationality and reason to simulate verisimilitude and universality. In this sense, History is a ruse instantiated and ratified in the imaginary of the West to establish and maintain the West's epistemological dominance over the rest. As a hegemonic project of colonialism, its nature and function is to assimilate and integrate all local particularities and temporalities into the pseudouniversality of the modern world system. By conceiving and convening the past in its 
own image (the European imaginary) the past then becomes the representative means whereby the Euro-American polity controls the present and shapes the future.

\section{Periodizing and Theories of Change}

Historical conventions or periodizations (paradigmatic stage conceptions of historical development) are products and producers of theory. They also serve as discrete systems of syntax and semantics that structure knowledge across vast distances and differences of human experience and existence. Terms such as Medieval, Dark Ages, and Renaissance have become so much a part of the common idiom of the dominant culture of Western Historiography that they hardly need defining or explanation. Thus, for example, it is not uncommon to see references to a medieval Japan or an African renaissance and assume such categorical descriptions are accurate and apposite. Applied universally to various stages of social change throughout the world irrespective of local differences, these epochal concepts are rooted in theories of historical change based on Europe's own local stages of development. Unquestionably, theories of change have their expository and didactic purposes, but such theories should be organic. That is, they should arise out of local or regional conceptual ground rather than be transplanted or implanted by the violent episteme of Eurocentrism. As Cesairé has pointed out, however, and the Eurocentrists themselves proclaim, History is an invention of "white" men; therefore its theories of change reflect their experiences and orientation. William A. Green's description of the theoretical orientations of "world historians" summarizes the parochial presuppositions that inform this process:

In the main, modern writers of world history texts have adopted progressive, evolutionary, materialist theories of change. Their theoretical orientation corresponds to that of the leading progressive and evolutionary theorists of the 
nineteenth century. Both have embraced human history from its origins to the present, trying to locate critical stages in humankind's long transition from hunters and gatherers to modern world citizens. Both have assumed that there are common and universal qualities to human nature and that human nature inevitably generates social and cultural development. Both have considered change to be gradual and constant; both have identified the direction of change as evolving from homogeneous to heterogeneous, from simple to complex; both have believed that, on balance, change has occasioned betterment in the quality of human life (nineteenth century scholars were boldly confident of this; contemporary world scholars make this case more subtly, sometimes even apologetically). Both have asked the same kinds of questions: how do people become civilized (1995, pp. 103-104).

Green is explicit and unapologetic in framing the work of contemporary world historians as an evolving discourse founded on the theoretical suppositions of their nineteenth century predecessors. Inferentially implicit in his statement is the fact that contemporary historiography is grounded in modes of thought established during the genocidal era of European colonial conquest. Nineteenth century Euro-American intellectuals assumed a progressive view that historical change "occasioned betterment in the quality of life" in part because they were the beneficiaries of the labor, productivity and genius of millions of non-Europeans whose enslavement and exploitation enabled Euro-America to expropriate and amass vast amounts of capital and wealth and significantly and simultaneously raise their standards of living and their expectations of life. From the perspective of the enslaved Yoruba woman shipped like cargo to the isle of Haiti in the eighteenth century to witness her compatriots decimated by the genocidal labor practices of French planters, the so-called Age of Enlightenment surely must have seemed like an Age of Darkness where decline, death and decay were the natural order and engines of historical change. But here, again, the critical question arises: what time is it? If all histories are mediated by European History, and historical thought functions almost exclusively as an agent of Eurocentrism, the local and regional histories of 
Africans, Amerindians and Asians, their perspectives of change and periodicity, and their experiences before and after contact with Europeans exist only insofar as they are positioned within or oriented to the History of Euro-America.

The question— "how do people become civilized?"—cited above by Green as a common concern of historians past and present, demonstrates an inherent bias in the formulation of historical research and discourse. Implicit in this question is the notion that civilization is a desirable goal for human societies to attain and that it has been attained at some particular time or place. The idea that some people are civilized, hence modern, while others function at various lower stages of development or evolution coheres in the philosophy of Voltaire, Hume, Herder, Hegel and other founding fathers of modern historiography (Breisach, 1994). This hierarchical differentiation of societies and its historical explanation rests most often on pseudo-scientific theories of race and white supremacy that were codified and canonized in the wake of the era of European conquest and colonization. Theories of race and racism provided the ideological basis for classifying and ranking non-European societies as savage, barbarian or simply backward, and depicting them as temporally lagging behind Europe in invention and innovation, morality and intellect. Anthropologist Johannes Fabian refers to the Eurocentric notion that a temporal difference exists between Europe and the rest of the world as: "the denial of coevalness" $(2002,2006)$. Accordingly, Europe has progressed far beyond the rest of the world due to the unique genius and capabilities of Europe's superior inhabitants. Euro-American culture, political economy, values and beliefs, therefore, comprise the future other societies evolve toward, with different regions, nations, or groups progressing at different rates according to their cultural/racial location or stage in the 
sociohistorical continuum. Following this logic (or illogic), hunter-gatherers reside in the primeval and pre-historic past, the past before time was invented, and thus have not yet entered history. Arab societies (especially Islamic states like Saudi Arabia and Iran) exist at feudalistic or medievalist stages: terms denoting their comparative cognitive and material stagnation and backwardness, but implying that modernity is just around the corner. Modernity, of course, is western. Non-western societies become modern only by becoming westernized. Capitalism, industrialization and democracy constitute the engines that convey underdeveloped states from the historical stasis or retardation of their pasts forward to modernity and the future.

The denial of coevalness demonstrates how Europeans, in colonizing the globe and filling in the blank spaces of terra incognito on their maps, colonized time and filled in the blank spaces of the past with the modern myths of History. Their colonizing mission also operated under the guise of a Christianizing mission and used the ancient myths of the Bible to subvert and supplant non-European belief systems and cosmologies in the name of advancing civilization and group and individual salvation. By these means colonialists sought to control the present (the now) and reinvent the future (the new) in their own images. Periodizations or stage theory in historiography, as paradigmatic projects that accompanied European expansion and colonialism, made the denial of coevalness theoretically possible. Stage theory, as promulgated by Condorcet, Hegel, Comte and others, marginalized Africa and Asia and provided the philosophical underpinnings for the temporal banishment of non-Europeans from the now and the new. Capitalism drove European global conquest, and conquest expanded the European capitalist system into a world economic model. Economic theories, in fact, dominate the 
basic models of historical change that Western scholars have used to formulate stage theory or periodizations in the modern era. According to Green, division-of-labor models, neo-Malthusian demographic models, Marxism, and world systems models, "are compatible with tripartite periodization and with its sixth- and sixteenth-century epochal divide" (1995, p. 103). More than compatible, however, I would argue that materialist explanations of social change sustain stage theory in a feedback loop whereby the two reinforce each other in producing modern History and its underlying episteme.

Economic theories in fact have surpassed ethnographic and anthropological analyses as the means to evaluate the central question raised above by William Green: "how do people become civilized?" It can be argued that the advent of modern era marks a break between the old deus ex machina explanations of social change and the emergence of new secular-materialist explanations. Part of this change in social analysis involves the conflation of capital with capitalism. Capital tends to mediate all forms of modern social production, but not all forms of production in the world can be described as capitalist, or, contrary to Marx and Engles, as linearly progressing through various stages of evolution to capitalism. In a sense it could be argued that the advent of postmodernism would entail a break with the materialist, and until that occurrence the world will remain completely in the acquisitive grasp of the modernist cultural imperative. But to posit this next step in social evolution suggests a moribund kind of thinking still trapped in the linear fallacies of periodizations or stage theory as explanations of social change.

The tripartite division of history represents the broader conceptualization or guiding principle of periodization that has been used to transform the local particularity 
of Europe into global History. The idea or concept of civilization constitutes the basic unit of observation that makes this system coherent. Civilization, defined from a European perspective and bias, thus becomes the abstract and arbitrary standard by which human societies are measured and evaluated. Green contends that, "all periodizations should be rooted in disciplined concepts of continuity and change," and argues for methodological rigor in linking various local histories into a global framework or design (1995, p. 101). Green also describes the inherent difficulties in integrating regional histories in any practical way until after 1492: "A completely integrated world history is only possible after the hemispheres were in permanent contact" (1995, p. 101). The underlying assumption of this statement is that fragmentation is a problem before Columbus' transatlantic voyage, and that after that decisive date an integrated history of the world is possible because the "rate and direction of change across diverse and distant cultures" can be studied and ascertained (Green, 1995, p. 101). What this means is that theories of change rooted in Europe's own development can be imposed and superimposed as "an integrated history of the world," once the local histories of the world have been fully integrated into the Euro-American hegemony and its elaborate cultural and human sacrificial cult of white supremacy. 


\section{THE SOCIAL CONSTRUCTION OF "RACE"}

The central question that confronts us in this inquiry into the cognitive developments of race and antiblack racism is: how and where did "black" people become black? Given the broad scientific consensus that there is no biological justification for the concept of race, this inquiry looks beyond the use of "black" as a term designating skin color or phenotype to its larger sociohistorical functions and implications. With the exception of a few people in Africa and India, human skin pigmentation that approximates the color black is uncommon. Similarly, "whiteness" too is more a pigment of the imagination than an accurate descriptor of human flesh tones. Given the lack of linguistic precision in the application of color terms to describe human individuals, and the subjectivity that comes into play in the descriptive process, it is essential we investigate what other factors contributed to the distinctions of social rank and status the notions of "blackness" and "whiteness" have come to denote and represent.

The investigation of these factors leads inexorably to encounters with bizarre and foolish ideas about human diversity. From Johann Friedrich Blumenbach's invention of the Caucasian, to the popular notion of a "one drop rule," to Thomas Jefferson's founding of the American school of scientific racism in his Notes of Virginia with his mathematic formulas for calculating degrees of blackness, the postulates and paradigms of race, whatever their sources or contents, will not stand up to even the most cursory scientific examination and analysis. Further evidence of this can be adduced from the lack of 
agreement among the founders and proponents of race theory as to the exact number of divisions of various races according to the principles and systems of taxonomic classification. Charles Darwin noted this fact in The Descent of Man:

Man has been studied more carefully than any other animal, and yet there is the greatest possible diversity amongst capable judges whether he should be classed as a single species or race, or as two (Virey), as three (Jacquinot), as four (Kant), five (Blumenbach), six (Buffon), seven (Hunter), eight (Agassiz), eleven (Pickering), fifteen (Bory de St-Vincent), sixteen (Desmoulins), twenty-two (Morton), sixty (Crawfurd), or as sixty-three, according to Burke. This diversity of judgment does not prove that the races ought not to be ranked as species, but it shews that they graduate into each other, and that it is hardly possible to discover clear distinctive characters between them (1871, p. 174).

Setting aside Darwin's conflation of the ideas of race and speciation, and his mischaracterization of Buffon's position on this subject, it is interesting to note that his conclusion about the lack of clear distinctions between races due to the manner in which they "graduate into each other" anticipates the contemporary use of the term "clines" by physical anthropologists and geneticists. That term is attributed to Frank Livingstone, who said—-"There are no races, there are only clines." Livingstone's neologism is intended to describe the "gradations" in the distribution of individual human biological traits. The descriptive concept of clines, however, can only be understood by first dispensing with the notion of race (Livingstone \& Dobzhansky, 1962, p. 279). If one is forced by the data to admit that individual biological traits "graduate into each other" then there also should be a willingness to recognize that in the socially constructed reality of the modern world the concepts of "blackness" and "whiteness" have much more to do with a person's supposed sociohistorical categorization or status than their somatic characteristics or outward physical appearance. Nevertheless, despite the demonstrable fallacy of such propositions, ideas of racial classification continue to be accepted in Euro- 
America, where the notions of race and the racism it engenders have been regarded as verifiable facts or scientific truths that have remained constant and fixed throughout the entire course of human existence. According to such beliefs a person is "white" because his ancestors were "white" (and of European origin)—with the social status and privilege implied by that designation— just as his descendants should be "white" in the future. If this supposition were true we would expect to find in the documents and artifacts of antiquity evidence of these ideas as operative principles of social organization and social philosophy. Brace, 2005; Drake, 1987; Fredrickson, 2002; Hannaford, 1996; Snowden, 1970, 1983; L. A. Thompson, 1989, and others have examined the history of racism and found it absent or lacking in antiquity. Even the recent massive study by Benjamin Isaac, The Invention of Racism in Classical Antiquity, still does not venture beyond the conclusion that only forms of so-called "proto-racism" existed in the Greco-Roman world, leading one to conclude that marketing, rather than scientific evidence, is responsible for the misleading title of his book (2004, p. 515).

Recent studies like Noel Ignatiev's How the Irish Became White (1995), and Theodore Allen's The Invention of the White Race (1994), delineate how the very ideas of whiteness and blackness developed out of a particular sociology of knowledge (or ignorance) derived from the sociohistorical interactions of specific human societies during the last few centuries. The popular beliefs or scholarly misconceptions that these socially constructed categories are grounded in biological or scientifically demonstrable facts of nature have given an aura of verisimilitude to the fiction of race as a valid classificatory scheme. The fact that Mother Nature has produced no biologic templates for race, and no predicates for white supremacy can be found in antiquity, has not 
diminished the luster and attractiveness of racial theory, or the pathological desire to transmit the illusion onward across generations to preserve the status quo of white privilege in the form of the Racial Contract that Charles W. Mills has defined and described (1997). How then do we go about the task of navigating the labyrinthine psychohistory of an illusion? It is my contention that the false construct known as the negro comes first in the elaborate rituals of racialization that led to the ceremonial investiture of the white man as ruler of the known universe. Consequently, we must examine first the invention of the negro and the concomitant evolution of blackness.

This thesis looks not only to the processes and procedures that led to the elaboration of the characteristics defined as negro or black, it also examines how these ideas were imposed on so-called black people, and how the people deemed black or who were thusly blackened responded to their racialization. While a number of scholars have tackled this problem, we will look briefly to the work of Frantz Fanon to ground this discussion and set us on a path to discover how blackness became a weapon in the arsenal of African American liberation discourses. In his landmark study A Dying Colonialism, Fanon offers a trenchant observation that illuminates the precise genealogy of modern "black" identity: "It is the white man who creates the Negro. But it is the Negro who creates Negritude" (1967, p. 47). Translated and updated for purposes of this essay, I would have Fanon say: It is the white man who creates the African. But it is the African who creates Afrocentrism. Fanon made this remark in the context of a discussion about the cultural resistance of the colonized to the colonizers' interference with local traditions: specifically, French attempts to unveil Algerian women during the colonial period of occupation as a means of "destructuring Algerian society" (1967, p. 46). $\mathrm{He}$ 
prefaced his statement about the invention of the "Negro" with this comment: "In an initial phase, it is the action, the plans of the occupier that determine the centers of resistance around which a people's will to survive becomes organized" (Fanon, 1967, p. 47). In the context of this discussion, it is analogous to say: the "action" of the enslaver in creating a commodity called negro from the human populations of the African continent determined the nature of "Negritude" (or Afrocentrism) as a center of resistance and survival.

Although Fanon's comment is grounded in an analysis of twentieth century colonialism it provides a useful lens for examining the complex issues and events surrounding the formation of black identity before, during, and after the cultural upheavals of transatlantic slave trade. Fanon's generic "white man," according to his analysis, created the dehumanizing conditions of racial slavery from which Diasporan African identities evolved. Hence the formation of modern black identity involves the confluence and transformation of two highly complex cultural templates: the negative European racial concepts of the 'negro,' and the positive ethnic attributes that constitute indigenous 'African' selfhood. To understand the nature of the composite and transcultural identity (the hyphenated Afro- Caribbean, Brazilian, Latin or American identity) that emerged out of this confrontation, and the antiblack racism that fostered it, we must first look at how the peoples of Africa became negroes in the Western mind, and negroes became slaves in the Western world. As historian William McKee Evans puts it: "For the purpose of understanding the rise of modern Western racial prejudices, it is important to consider the historical process whereby a people acquires or loses a slavish reputation, whereby slavery acquires or loses an ethnic identification" (1980, p. 17). 
Evans' comment returns us briefly to the constructionist nature of racial discourse. The idea of race as a sociohistorical construction has achieved wide acceptance in academic circles during the latter half of the last century. Yet no scholarly agreement currently exists concerning the etiology of this idea and its most virulent form of social expression: antiblack racism. Early modern racial theorists David Hume (17111776) and Barthold Georg Niebuhr (1776-1831) posited an ancient pedigree for racism, citing their interpretations of the works of Plato and Aristotle for that purpose (Hannaford, 1996, pp. 216, 240). Herman Hoetink, Carl Degler and Winthrop Jordan are among recent scholars who have emphasized the role of skin color and somatic prejudices in the development of racist thought (Drake, 1987, pp. 43-62; Jordan, 1968, 1974). Oliver Cromwell Cox (1948), Eric Williams (1994), and Walter Rodney (1974), using Marxist analysis, identified the transatlantic slave trade and the development of capitalism as the underlying forces of racial animus. These three general theories all fall conceptually short of the mark in identifying the precise origins of antiblack racism. The advocates of "ancient racism" looked backwards upon the ancient world through the lens of their own racist views and thereby confirmed the fallacies of their own presuppositions. Those who posit a universal antipathy to blackness and black people based upon a psychological fear and dread of the dark fail to consider the variability of skin color, the variability of responses to it in societies around the globe, and assume that what may be true in modern Western cultures is the norm for others. The Marxist critics, although correct in postulating a "modern" origin of racism, fail to consider how religious beliefs and modes of thought not founded or grounded in materialism or class struggle 
could have inspired and informed essentialist and racialist views before the transatlantic slave trade and the development of capitalism.

What other methods or theories then can be applied to this set of problems? Perhaps we can uncover significant cognitive traces of the origins of racism by tracing the origin and evolution of racial terms like negro. This method, however, requires attention to certain analytical problems. In moving backwards in time negro loses its significance and coherence as a foundation stone in the socially constructed edifice of modern racism. Jack Forbes in his groundbreaking study, Africans and Native Americans, raises an important point about the elasticity of the term: "We may think we know what the word 'negro' means today but do we know what it meant in 1800 in Virginia?" (1993, p. 3). Following Forbes' lead we also might ask what it meant in late medieval Europe, in the mid-fifteenth century, when Portuguese raiders seized the first victims of the Atlantic slave trade from the coast of Upper Guinea for sale in Lisbon. Such an inquiry, however, no matter how problematic, may still help us determine why negro became a pejorative label for African people, how it became a synonym for slave, and where this confluence took place.

Removing the pseudo-scientific connotations negro accrued during the invention of race in the seventeenth and eighteenth centuries leaves us with a generic term for "black" or "dark" that, when applied to human beings, referred indiscriminately to Europeans and non-Europeans alike based solely and arbitrarily on subjective perceptions of skin color. Its derivation from Latin (from niger or negri, meaning "black" or "dark") reveals its deep roots in European culture centuries before its usage in medieval Spanish, Portuguese and Italian (Forbes, 1993; Snowden, 1970). Keeping Forbes' warning in 
mind, it is useful, nonetheless, to view medieval uses of negro as an integral part of the symbolism and allegory employed by European Christians in the construction of a Manichean distinction between themselves and 'Others' (specifically non-Christians they encountered or confronted). Manichaeanism (founded by Mani, c. 210-276 CE) describes an ancient Persian religious worldview that posits existence as an eternal struggle between the forces of Darkness and Light. It is borrowed here from Fanon's analysis in The Wretched of the Earth (1965) of the implacable opposition between colonizers and colonized. From the Fanonian standpoint, and from the perspective of postcolonial analysis, Manichaeanism manifests and operates through the adoption of a binary ideological structure that polarizes the very being of the colonizer and colonized into explicit and irreconcilable allegorical categories of good and evil. JanMohammed popularized the use of this concept in postcolonial studies dealing with imperialism (1985). But it is applied here to the opposition between Christian and Muslim, and European and non-European. Christian is good, and non-Christian (Muslim, Jew, Pagan) is evil. Most important to this discussion, white is good and black is evil. Fanon describes this dichotomy in Black Skin, White Masks, as follows:

In Europe, the Negro has one function: that of symbolizing the lower emotions, the baser inclinations, the dark side of the soul. In the collective unconscious of homo occidentalis, the Negro- or if one prefers, the color black—symbolizes evil, sin, wretchedness, death war, famine (1968, p. 40).

Existentialism, Marxism and Freudian theory converge in Fanon's Manichaean analysis of the black/white dichotomy. The problem with this formulation lies in its sense of absoluteness and universality. Although any English dictionary will confirm Fanon's analysis of the negative meanings of the color "black" (and the same can be said of other European languages), its applicability to skin color is no more static than skin color itself, 
and depends on the time, the place, and the circumstances. Forbes has documented the use of terms like nigri, preto, loro, rufo, olivestre in late medieval Italy and Iberia, citing their lack of specificity in describing skin color $(1993,66)$. He also provides examples of the use of negro by the Portuguese to describe Amerindians (Forbes, 1993, pp. 69-71). The issue of subjectivity cannot be overemphasized here. Different European encounters and interactions with non-Europeans - trade, warfare, conquest, and colonizationinfluenced or determined the nature and perception of otherness.

Sociologist St. Clair Drake has labeled Frantz Fanon, Roger Bastide, Carl Degler, Kenneth J. Gergen, Winthrop Jordan and others the "Modern Manichaeans" for their use of Manichaeanism as a "secularized metaphor" in their analysis of prejudice and antiblack racism (Drake, 1987, p. 63). Fanon limited his use of this metaphor to "homo occidentalis." But others have used it to support their theory that prejudice against "black" as a color (and hence against "black" people) is grounded in a universal human fear and hatred of darkness. The proponents of this view contend that through a process of "unconscious association" negative ideas symbolized by the color black in the minds of white folk attached to 'dark-skinned' folk they encountered. In Drake's opinion this argument amounts to nothing more than the theoretical essentializing of racial prejudice (Drake, 1987, pp. 67-75).

While I accept Drake's deconstruction of the Modern Manichaean theory and the falseness of its premise when it is applied to denote a universal antipathy to blackness, I contend the Manichaean metaphor can serve another analytical purpose. Its religious etiology and metaphysical dualism provide a useful frame of reference for identifying and describing the cognitive steps leading to the construction of race and antiblack racism, a 
process it is argued here, in which the confrontation between Christianity and Islam, particularly in Iberia, constitutes a decisive stage. Anthropologist Roger Bastide's description of the Christian variety of Manichaean dualism carries us a step further in that direction:

The Christian symbolism of color is very rich ... But the greatest two-part division is that of white and black. White is used to express the pure, while black expresses the diabolical. The conflict between Christ and Satan, the spiritual and the carnal, good and evil came finally to be expressed by the conflict between white and black, which underlines and synthesizes all others [...] Whiteness brings to mind the light, ascension into the bright realm, the immaculateness of virgin snow, the white dove of the Holy Spirit, and the transparency of limpid air; blackness suggests the infernal streams of the bowels of the earth, the pits of hell, the devil's color (1967, p. 314).

Bastide captures the essence of the Manichaean metaphor in this passage;

moreover, his claim that the conflict between white and black in Christian symbolism "underlines and synthesizes all others," accurately describes the polemical use of symbolic "blackness" in Christian literature. Despite the widespread worship of Black Madonnas throughout Europe, other "black" presences in Christian iconography, and awareness in Europe of Christian communities in Africa from the religion's historic beginnings, the negativity of "blackness" in Christian thought remains a salient feature of what New Testament scholar Gay L. Byron refers to as the "ethno-political rhetorics" of the early Christian writings (2002, pp. 1-2). The secular and universalized psychological notions of "blackness" and "whiteness" that inform the Modern Manichaean model, however, developed from the sociohistorical interactions of specific human societies, as stated above. Accordingly, since a "white" person is not "white" by nature, the very idea of "whiteness" must be born out of a particular sociology of knowledge (or ignorance). The proof of this theorem rests with the simple fact that Europeans had to come in 
contact with other groups in other areas of the world to be able to perceive the phenotypic differences that thus enabled them to contrast their appearance with that of others. Moreover, they also would require some basic sense of the other ethnic attributes and characteristics (languages, customs, cultural institutions) of these various groups to make such differences comprehensible and meaningful. Bastide's contention that the Manichaean symbolism ultimately acquired a somatic or racial significance and consequence is not in dispute. But the assumptions by Bastide, Degler, Gergen, et al. that the color symbolism of blackness and whiteness operated automatically throughout human existence as a secular metaphor for racial differences "when a white person finds himself in contact with a colored person" does not stand up to empirical analysis (Drake, 1987, p. 62).

How various peoples in the so-called ancient world defined and accounted for human diversity will receive some attention below. But here it is important to point out that the Modern Manichaeans - in their ambition to locate the metaphorical roots of the black/white dichotomy in the deep structures of human psychology—glossed over the religious ground from which these ideas emerged. They therefore missed an important opportunity to consider the role of the monotheistic religious dichotomy of believer/nonbeliever in establishing a template for the conceptualization of essential ideological differences that later would become racial distinctions. This thesis identifies and examines the process whereby religious distinctions associated with the monotheisms of Judaism, Christianity and Islam provided the critical frame of reference, terminology and social practice for the emergence of racial distinctions and racism. Returning the Manichaean metaphor to its original context re-establishes the religious pathways 
whereby the black/white dichotomy enters medieval European thought and informs the psychosocial and economic processes and policies that fostered the establishment of racial slavery and colonialism that Fanon correctly describes. Centuries before European colonialism and before the natural philosophers of the Enlightenment era codified and canonized the pseudo-scientific tenets of modern racism, distinctions between Jews and Gentiles, Christians and pagans, Muslims and infidels provided a typology for racism and a theological justification for racial slavery.

Although membership in a particular monotheistic faith often fostered a kind of group identity that transcended ethnic and linguistic boundaries-particularly as these faiths presented themselves as universalistic and sought to expand their power and reach through conversion—group identity or membership also was maintained and reinforced by mandating and perpetuating otherness through institutionalized intolerance and violence towards non-believers (Schwartz, 1997, p. 31). Thus 'otherness,' as defined by the believer/non-believer dichotomy, remained central to the group's ability to define itself. Consequently, despite becoming genuine adherents to the faith, some converts still could not escape the taint of otherness that clung to them. This was especially true when those new converts were readily identifiable due to their outward physical appearance. Thus, as we shall see later, many dark-skinned Sudanese converts to Islam, despite their efforts to become exemplary Muslims, were not able to escape enslavement by Arab Muslims in Morocco and elsewhere in North Africa. Being perceived as other, even within the brotherhood and sisterhood of a particular monotheistic faith, could and often did trump membership in the religious fraternity. 
Somatic differences and prejudices, in this instance, also determined and amplified perceptions of otherness. Somatic prejudices alone, however, do not constitute racism. While such attitudes often lead to group stereotyping, as Lloyd Thompson documents in his detailed study of Romans and Blacks, the presence of "sensory aversion to nigritude" in Roman society, for example, did not prove to be an impassible barrier to social mobility despite the fact most Africans who lived in Rome were concentrated in the lowest and most menial of occupations (1989, p. 25).

It is my contention, therefore, that the sociohistorical encounters of Africans with Europeans and Arabs within geographic and societal venues of conflict, conquest and enslavement, coupled with monotheistic religious antipathy toward nonbelievers (especially so-called pagans), and somatic prejudices against blackness, produced a cognitive template for the formulation of black and white identities, racial slavery, and the later emergence of antiblack racism. The othering of blackness thus proceeded first according to a monotheistic Manichaeanism that identified Africans as nonbelievers, and then progressed to incorporate other negative perceptions commonly associated with African phenotypic characteristics. Ignorance, fear, somatic prejudice, mistrust—all contributed in varying degrees to the construction of the Otherisms that formed and informed the construction of the negro. According to anthropologist C. Loring Brace: "Of all the various isms, this mistrust of the "other"—one could call it "otherism"—is arguably the most problematic. Otherism, elsewhere called "otherness," in fact is the basis for racism" (author's italics) (2005, p. 268).

Perhaps at this juncture it is also useful to draw an important distinction between the concept of difference and that of otherness in the analysis of the evolution of racism 
articulated in this thesis. My preference for the term "otherness" is that unlike "difference"-which in my opinion is best used to denote the natural phenotypic or somatic differences that constitute human diversity—“otherness" denotes something extremely different, so different that mere "difference" cannot accommodate the degree of distinction, hence it is "Other." As "Other," it is opposite the socially constructed and localized European norms. As "Other" it is the inversion of those norms, in its dehumanization, sexualization and stereotypic personification of evil. Hence it is "The Black One" (ho melas), a reference to the devil in Apostolic Christian discourse (Byron, 2002, p. 60); or the "Black Stud" in medieval Spain, embodying all the signs and symbols of hypersexuality and fatal attractions (Piedra, 1993); or a "thing of darkness," like Caliban in Shakespeare's The Tempest (Hall, 1995, p. 142). Otherness comprises all those negative "things" and more. In the chapters that follow I hope to demonstrate how "difference" (human diversity) began to be viewed through the lens of monotheist dichotomy of believer/non-believer to produce an "Otherness" so irredeemably different that it defined and labeled the majority of the world's inhabitants as subhuman.

Postcolonial theory has much to say about the construction of 'Other' as a means of defining 'Self' in the western cultural tradition. As is argued here, the roots of this metaphysical dualism are implicit in the monotheistic distinctions in Judaism, Christianity and Islam between believers and non-believers. The othering of 'Africans' follows this pattern before the racializing of 'Africans' occurred. Once labeled as pagans and infidels, this difference was extrapolated to form a constellation of "Other" characteristics (sexual, cultural, somatic) conceived as the polar opposites or inversions of monotheistic (Jewish, Christian or Muslim) norms. In constructing the negro as 
inferior, ungodly and evil, Europeans and others constructed themselves as superior, godly, and good. Thus the stereotypic and Manicheanistic invention of the negro became the central means whereby white people invented themselves. Unarguably, in this "chicken or egg" process, the negro came first.

The conceptual roots of the believer/non-believer monotheistic dichotomy are found in the sacred writings of Judaism: the religious nexus of Christian and Islamic doctrine and traditions. Judaism also figured significantly in the religious life and cultural wars of medieval Iberia. There, in the westernmost outpost of the European continent, three monotheistic faiths, Judaism, Christianity and Islam, and the Islamic and Christian trade in "black" slaves, converged and created the social contexts and sociology of knowledge that produced modern racial ideology and Eurocentrism. The term sociology of knowledge, as used here, refers to the social construction of reality from what generally is accepted as known and real within a given society irrespective of the truth or falseness of epistemology upon which it is founded (Berger \& Luckmann, 1967). The establishment of an existential view of "Self" and "Others" based on such knowledge is what concerns us in this thesis. The starting point for this discussion is Judaism and the role of its particular brand of monotheism in the formation of the "Other." Two traditions in Jewish literature figure decisively in the invention of "black" identity in Europe. The first tradition involves what renowned Egyptologist Jan Assmann refers to as the "Mosaic distinction" $(1996,1997)$. The second tradition involves the biblical story of the sons of Noah and the curse of Ham. Both are found in the Hebrew Bible. 


\section{JUDAISM AND THE INVENTION OF THE COUNTERRELIGION}

Israel Finkelstein and Neil Asher Silberman in their controversial study, The Bible Unearthed, describe the Hebrew Bible as "... a collection of legend, law, poetry, prophesy, philosophy, and history, written almost entirely in Hebrew (with a few passages in a variant Semitic dialect called Aramaic, which came to be the lingua franca of the Middle East after 600 BCE)" (2001, pp. 5-6). Recent biblical scholarship suggests at least four diverse source documents belonging to different epochs and known variously as J (Jahweh), E (Elohim), P (Priestly) and D (Deuteronomy) provided the materials from which the Hebrew Bible was composed. Some scholars contend their final reconstruction and compilation occurred during the fifth century BCE (Armstrong, 1993, p. 12). No biblical texts currently exist, however, that can be dated earlier than the third century BCE.

Who wrote the Bible? William Schniedewind has tackled this popular question in his study of how the Bible was written. According to Schniedewind, the authorship of the Bible was not considered an important issue "until after the rise of Greek civilization in the fourth century B.C.E.-well after most of the books of the Bible had been written" (2004, p. 7). He cites "the fall of the Persian Empire to Alexander the Great" as ushering in an age of Hellenism in the Near East that spread Greek culture and language throughout the region and bringing with it the notion of authorship and its association 
with the authority of a text (Schniedewind, 2004, p. 7). Schniedewind also notes that the Classical Hebrew language does not have a word for "author." The closest term found in the language is sofer (scribe) (Schniedewind, 2004). The designation scribe more aptly describes the bureaucratic functions of the position and its role in passing on the traditions of ancient Israelite society, rather than that of the authorship of texts. With ancient Israel being a largely oral society, the stories and traditions that eventually made their way into written form were existent centuries before they were recorded for posterity. Thus scribes performed the principle tasks of collecting, recording and editing the common heritage of poetry, oral stories and traditions that were assembled and canonized over the course of many centuries (Schniedewind, 2004).

As for the particular methods of writing employed and their instruction, Schniedewind discusses the existence and role of scribal schools in the Near East: "Scribes throughout the region learned the scribal arts in loosely connected panLevantine scribal schools. The affinities between Ugaritic and biblical poetry-especially early biblical poetry - thus point to Canaanite tradition as the heritage of early Israelite scribes" (2004, p. 47). Mark Smith also sees the seminal influences of Ugaritic texts on the origins of Jewish monotheism and the composition of biblical texts. Smith, however, cautiously avoids the use of the term Canaanite as a geographical and cultural descriptor, citing problems in defining it (2001). Schniedewind and Smith both cite texts and other evidence showing clear relationships between the concepts of divinity found in the Ugaritic texts and those found in the Bible. Nevertheless, it is possible to trace the cultural and literary origins of these traditions to even earlier sources in Africa and Mesopotamia. According to E.W. Heaton, the roots of this Ugaritic/Canaanite tradition 
can be traced to the Egyptian scribal schools of the third millennium BCE: "To acknowledge the possibility that the scribes of Solomon's court were indebted to Phoenicia for its literature no less than for its timber and technicians is not necessarily to abandon the hypothesis that they were primarily heirs to the classical tradition of Egypt" (1974, p. 163). Gray Greenberg also has explored the Ancient Egyptian roots of the Bible and concluded:

The lack of attention to Egyptian influences on the Bible by both biblical scholars and Egyptologists is unfortunate. A conscious and deliberate effort exists to keep to the spheres separate, yet the Bible shows a long and continuous relationship between ancient Israel and Egypt. It places Israel's formative years in Egypt, living an Egyptian lifestyle, educated in Egyptian ideals, and dwelling there for centuries before the Exodus.... Moses according to the biblical account, was raised and educated in the Egyptian royal court, and many members of his tribe, Levi, have Egyptian names (2000, p. x)

Other scholars who have studied the literature of early Israel also see many influences in subject and style from the vast repository of sacred writings, wisdom literature, and popular tales that were created in Ancient Egypt and disseminated throughout North Africa and the Near East: Adamo (1986), Assmann (1996, 1997), Massey (1907a, 1907b), Thompson (1999), Zabkar (1954). And, as stated above, still others find the ancient civilizations of Mesopotamia as an influential source of myths, legends and literature in the Near East: Applegate, (2000); Choksy, (2003); Graves \& Patai (1983).

The use of diverse source materials to compose the Bible, particularly the use of widely circulating myths, legends and tales from Africa and the Near East, raises critical questions about the fictional nature of biblical narratives. These questions go to the manner in which the biblical past is constructed in the various books of the Bible and how that past is interpreted and used in the eventual establishment of the monotheist 
doctrines of Judaism, Christianity and Islam. The view of biblical literature presented here is that it was conceived in the form of a fictionalized historical account of the Israelite past to convey a series of warnings and injunctions for the people of Israel to be pious and respect the moral authority of god's law. Thus any attempts to read history into these accounts will be fraught with failure. Thomas L. Thompson analyzes the findings of modern archeology and compares those data to the purported ancient historical "facts" as presented in the Bible. He concludes that the Bible is constructed as a literary fiction of the past, rather than as a chronicle of a specific historical past:

In writing about the historical developments of Palestine between 1250 and 568, all of the traditional answers given for the origins and development of 'Israel' have to be discarded. The patriarchs of Genesis were not historical. The assertion that 'Israel' was already a people before entering Palestine whether in these stories or in those of Joshua has no historical foundation. No massive military campaign of invading nomadic 'Israelites' ever conquered Palestine. There never was an ethnically distinct 'Canaanite' population whom 'Israelites' displaced. There was no 'period of the Judges' in history. No empire ever ruled a 'united monarchy' from Jerusalem. No ethnically coherent 'Israelite' nation ever existed at all. No political, ethnic or historical bond existed between the state that was called Israel or the 'house of Omri' and the town of Jerusalem and the state of Judah. In history, neither Jerusalem nor Judah ever shared an identity with Israel before the rule of Hasmoneans in the Hellenistic period. In short, the only historical Israel to speak of is the people of the small highland state which, having lost its political autonomy in the last quarter of the eighth century, has been consistently ignored by historians and Bible scholars alike (T. Thompson, 1999, p. 190).

Perhaps nothing better underscores the fictional nature of biblical narrative than the attribution by tradition of the authorship of first five books of the Hebrew Bible known as the Torah (Law) or Pentateuch ("five books" in Greek)— to Moses, a legendary Jewish lawgiver and prophet of whom no historical traces have ever been found. Moses has been imagined as everything from a magician, to an Egyptian priest, to an Egyptian Pharaoh, to a Persian hero (Freud, 1967; Kilcher, 2004; Osman, 1990; Zlotnick-Sivan, 
2004). Part of the controversy surrounding the identity of the legendary founder of

biblical monotheism comes from his name:

The only statement in the Old Testament itself concerning the origin of Moses' name comes at the end of the familiar story of Moses' birth presented in Exodus 2:1-10. When the daughter of Pharoah [sic] opens the basket and finds the infant Moses, "She took pity on him and said, 'This is one of the Hebrews' children.' . . . and he became her son; and she named him Moses, for she said 'Because I drew him out of the water.' The etymology of Moses' name presented in the last line above seems to be suggesting that that name, which is pronounced "Mosheh" in Hebrew, is derived from the Hebrew root "masheh," which means "to draw out." Quite apart from the implausibility of an Egyptian princess who spoke Hebrew, many commentators (Daiches 1975:34; Gray 1971:38; Rylaarsdam and Park 1952:861) have pointed out that while "Mosheh" might be stretched to imply the active label "one who draws out," it cannot be stretched to imply the passive label "one who is drawn out." For most modern Biblical scholars, of course, there is no great mystery about the meaning of "Moses"; it almost certainly corresponds to the suffix-variously spelled "moses," "mose," "mes," and so forth-appended to Egyptian names in order to denote "son of" or "descendant of." This suffix appears in the names of the Pharaohs: Ahmose, Thutmoses, Rameses, and so on. The Egyptian origin of Moses' name was, of course, a key bit of data adduced by Freud (1964 [1939]) in support of his hypothesis that Moses really was an Egyptian. In any event, most commentators suggest that the folk etymology in Exodus 2:1-10 is a fairly clumsy attempt to provide a Hebrew origin for an otherwise Egyptian name (Carroll, 1985, p. 775).

Regardless of how Moses is viewed as a personage over the centuries, he is accredited with a signal achievement in the creation of the Bible and in the initiation of a spiritual revolution in the ancient world. Moses' Torah embodies and articulates a religious ideology that marks a decisive break with all religious thought that preceded it. Egyptologist Jan Assmann has labeled this doctrine a "counterreligion." He states: "We may call this a "counterreligion" because it not only constructed but rejected and repudiated everything that went before and everything outside itself as paganism" (Assmann, 1996, p. 49). Assmann applied George Spencer Brown's “first Law of Construction," a methodology of mathematics and logic, to formulate his analysis and explanation of the counterreligion's social construction. According to Assmann, Brown's 
procedure operates as follows: "Draw a distinction. Call it the first distinction. Call the space in which it is drawn the space severed or cloven by the distinction" (Assmann, 1997, p. 1).

The monotheistic concept embodied in the Torah drew a distinction between the religion of the Israelites and all other existent religions. We will call this the "first distinction" or revelation of a "true" god. The cosmologic space of ancient religion is the space severed by the distinction drawn between believers in the "true" god (Jews) and non-believers (Pagans). The term "pagan" denotes not only anyone who is not a Jew, but also anyone who is not Christian or Muslim. It pejoratively connotes: a worshipper of "false" gods. This concept of "falseness" does not exist in paganism or so-called polytheism (referred to hereafter as cosmotheism). As Assmann points out, "the [pagan] gods were international because they were cosmic, and while different peoples worshipped different gods, nobody contested the reality of foreign gods and the legitimacy of foreign forms of worship" (1996, p. 49).

The vital spheres of interactivity within which all humans exist-the sun, moon and stars, the natural world and the forces of nature-furnished cosmotheism with a semantic dimension from which developed a system of "translation" that negotiated religious distinctions through a mutually intelligible cosmic vocabulary and idiom. Assmann estimates the civilizations of ancient Africa and the Near East achieved "cosmotheistic compatibility" sometime during the second millennium BCE (1997, p. 45). The Roman historian Plutarch, in his famous treatise on Isis and Osiris written during the first century CE, offers this lucid description of the philosophy and functionality of cosmotheistic translation: 
Nor do we regard the gods as different among different peoples nor as barbarian and Greek and as southern and northern. But just as the sun, moon, heaven, earth and sea are common to all, though they are given various names by the varying peoples, so it is with the one reason (logos) which orders these things and the one providence which has charge of them, and the assistant powers which are assigned to everything: they are given different honours and modes of address among different peoples according to custom ...(quoted in Assmann, 1997, p. 49).

By introducing the true-false distinction in religion the counterreligion made intercultural estrangement normative. As Assmann puts it: "False gods cannot be translated" (1997, p. 50). Assmann labels this theological conception "the Mosaic distinction" because tradition ascribes the "revelation" of the counterreligion to Moses. As the legendary author of the Torah, Moses, more than Abraham, should be accredited as the founding father of Judaism. As lawgiver he reveals the Ten Commandments to god's chosen people, the first of which-"Thou shalt have no other gods before me"instantiates the founding statement of the counterreligion (Exodus 20:3). This trope of divine revelation is central to Judaism and the spiritual and intellectual life of western civilization. Yet this intellectual and literary tradition is seldom considered within the African context in which it originated.

Biblical traditions claim Moses was born in the Nile Valley and that the Israelite people sojourned there for over four centuries. Of greater significance is the fact that the "Mosaic distinction" came after a religious revolution led by Amenophis IV, the Egyptian king who called himself Akhenaten. This Eighteen Dynasty ruler-who was lost to history until Egyptologists rediscovered his capital city Amarna in the late nineteenth century — founded the first known counterreligion in the fourteenth century BCE (Assmann, 1997, pp. 23-29). Variously dubbed by Egyptologists “Atenism” or the "Amarna" religion, Akhenaten's monotheism was a cosmotheistic monotheism that 
identified the sun or solar disc, a cosmic symbol, as the theomorphic image of its one "god." Using his power as head of the Egyptian state, Akhenaten inaugurated a fundamentalist crusade that banished all other forms of worship, excluded the practice of magical rites, and proselytized a religious dogma that was decidedly and defensively aniconic. Akhenaten's inversion of traditional Egyptian religion led Egyptologist Donald Redford to label him the "Heretic King" (1984). Soon after Akhenaten's death, however, his capital city Amarna was destroyed, his name was erased from historical records, and Atenism vanished from human memory. Lasting a mere sixteen years (circa 1350-1334 BCE), the Amarna revolution was quickly swept away in the counter-reformation led by the cosmotheists in their return to power (Redford, 1984). However, the remnants of Akhenaten's revolution survived in fragmented archeological remains and in cognitive sparks that may have influenced the ancestors of the Israelites, and through them, various traditions that informed Christianity and Islam (Zabkar, 1954).

Scholars throughout the ages, from the Egyptian priest Manetho (third century BCE) to Sigmund Freud, have attempted to recover the Egyptian roots of the Mosaic distinction. Freud's study, Moses and Monotheism (1967), is among the more notable efforts; in it he depicts Moses and his followers as Atenist refugees who fled the Nile Valley for the Land of Canaan. Freud's work tapped into similar theories held by earlier European scholars John Spencer, William Warburton, Karl Reinhold and Friedrich Schiller (Assmann, 1997). In a more recent work, The Moses Mystery: The African Origins of the Jewish People, biblical scholar Gary Greenberg, using a method he devised to compare Egyptian King Lists with Old Testament genealogies, contends the Israelites originated during the reign of Akhenaten, and that the Torah is based almost 
entirely on Egyptian history (1996). The Egyptian roots of the counterreligion notwithstanding, the concept is elaborated and transmitted through the sacralized texts of the Israelites, which depicted Egypt as the very icon of idolatry and iniquity while preserving and expanding the legacy of its failed monotheistic revolution through its own Jewish mythic traditions.

Preceding the tale of Moses and the Jewish exodus, the Torah relates a prior and equally significant theological severing of the unity of the human family. This occurs in the form of a curse that divides one group of people from the rest of humankind by consigning them and their descendants to a permanent servile caste. We will refer to the curse and its consequences of "ethnic" slavery as the "Noachic distinction" because Jewish traditions attribute it to Noah, a legendary biblical patriarch. Noah's curse on his son Ham authorized and justified the transgenerational enslavement of Canaan, the legendary ancestor of a number of notable Afro-Asian populations. Ham was the father of Canaan, and his alleged transgression is perhaps the most notorious example of the "sins of the father" being visited upon the son. Later interpretations of the curse furnished a definitive theological gloss in the construction of race and the racialization of slavery in medieval and modern eras. To understand the evolution of the Noachic distinction and its implications for generations of "African" people, we must now turn to the first book of the Torah: Genesis.

According to the Hebrew Bible, after a mere nine generations including that of Adam and Eve, the god of Genesis destroyed his iniquitous creation, sparing only the lives of one pious family, that of Noah and his three sons, and selected male and female pairs of every living creature, all of whom were rescued and transported in a great ark. 
Following this account of god's genocidal wrath, Genesis 9:20-27 relates how Ham entered his father Noah's tent and saw him naked, drunk and unconscious. When Ham told his brothers Shem and Japheth about their father's condition, they hastened to cover him while averting their eyes. Noah then awoke from his stupor aware of what had transpired and inexplicably punished Ham by cursing his son and all his descendants: "Cursed be Canaan; a servant shall be unto his brethren ... blessed be the Lord God of Shem; and Canaan shall be his servant. God shall enlarge Japheth, and he shall dwell in the tents of Shem; and Canaan shall be his servant" (Genesis 9:25-27).

A common interpretation of this myth contends Noah reacted to Ham's insult to his manhood by punishing Ham's manhood through his progeny. The amorality of the curse—its disproportionate punishment for what seems like a minor infraction—has invited numerous other speculations and explanations. Robert Graves and Raphael Patai, in Hebrew Myths, typologically locate Ham's conflict with Noah within the cycle of astronomical myths that recount a cosmic war for the throne of Heaven. The Greek myths concerning five brothers led by Cronus who conspire against their father Uranus, and the Hittite myths concerning the Supreme God Anu and his rebel son Kumarbi, are typical of these tales. Both stories involve castration. The divine sons castrate their father-gods to supplant them and seize control of their procreative functions (Graves \& Patai, 1983). Seeing Noah as a mutilated and aggrieved divinity adds plausibility to both his authority to curse living and unborn generations and the curse's severity. However, the biblical editors who converted Noah from a divine to a human father may have been compelled for ideological reasons to remove this literary motif. Patai and Graves cite Deuteronomy 23:1—which forbids the membership of eunuchs in God's congregation—as the reason 
Noah's castration was suppressed (1983, p. 124). Accordingly, Noah's loss of manhood would have subverted his sacred patristic role in Jewish tradition.

Several Midrashim (early rabbinic exegetical treatises on biblical texts) written between the second and sixth centuries CE theorize about castration and various other sexual offenses in attempts to explain Noah's transgenerational curse on Ham's progeny. The authors of these theoretical glosses speculate that Ham had sex with his wife in the ark despite Noah's edict that all, including animals, abstain; that Ham committed acts of bestiality; or that he sodomized his father. These same biblical commentaries supposedly link Noah's curse to Ham's purported "blackness." The following passage in the Sanhedrin 108b, a tractate of the Babylonian and Palestinian Talmud (circa 500—600 $\mathrm{CE})$, exemplifies this type of rhetoric in early Jewish writing: "The teachers say that three copulated with their females in the ark: the dog, the crow and Ham, and all were punished. The dog because it is stuck to its female when it copulates, the crow spits [and] copulates spitting, Ham because of this was cursed" (Goldenberg, 2003, pp. 291, n. 64). Blackburn offers a different translation of this tractate: "The dog was doomed to be tied, the raven expectorates (his seed into his mate's mouth) and Ham was smitten in his skin" (1997a, pp. 88-89). Although the phrase "smitten in his skin" is rather vague, the Genesis Rabbah (compiled in Palestine circa 600 CE), and the Tanhuma Noah (circa fourth century CE) furnish more specific details of Ham's punishment. Their authors assert that Ham's alleged sexual depravities led to his being cursed with "ugly and dark-skinned" descendants or to his becoming "black-skinned" (Graves \& Patai, 1983, p. 121).

These rabbinic references to Ham or Canaan's complexion have been the subject of much hermeneutic exercise and contention. Graves and Patai compiled and edited 
several of these comments (including the two cited immediately above) into a single paragraph that is highly misleading in its construction and presentation. The controversial passage is as follows:

Others say that Ham himself unmanned Noah who, awakening from his drunken sleep and understanding what had been done to him, cried: 'Now I cannot beget the fourth son whose children I would have ordered to serve you and your brothers! Therefore it must be Canaan, your first-born, whom they enslave. And since you have disabled me from doing ugly things in the blackness of night, Canaan's children shall be born ugly and black! Moreover, because you twisted your head around to see my nakedness, your grandchildren's hair shall be twisted into kinks, and their eyes red; again, because your lips jested at my misfortune, theirs shall swell; and because you neglected my nakedness, they shall go naked, and their male member shall be shamefully elongated.' Men of this race are called Negroes; their forefather Canaan commanded them to love theft and fornication, to be banded together in hatred of their masters and never to tell the truth (Graves \& Patai, 1983, p. 121).

Studies by Winthrop Jordan (1968) and Edith R. Sanders (1969), among others, have quoted and cited this emended text to varying degrees and with decidedly problematic results. However, the lack of clear attributions and dates for these various selected passages in Graves' book does not alter the fact that taken independently they represent accurate quotes from well-documented sources. Benjamin Braude (1997), Werner Sollors (1997), and David Brion Davis (1984) stress that these few and scattered commentaries, whatever their intentions, should not be accorded a unique status or role in Jewish history and thought. While it is true that other commentaries on Genesis omit these particular glosses or convey different interpretations of Noah's curse, the legacy of these Midrashim cannot be easily dismissed. In later Christian and Muslim thought they supplied a theological justification, no matter how spurious or misinterpreted, for the enslavement of people of African descent. 
Most theories about Ham and Canaan, however, remained grounded in interpretations of biblical rather than extra-biblical texts. Graves and Patai point out that Ham — which they claim means "heat" in Hebrew—is "identified by a play on words in Psalms 105:23 and 106:22 with Kemi, 'black,' a name given to Egypt ..." (1983, p. 122). Afrocentric scholar Charles Finch asserts Kam or Kemi: "is the strongest word in the Egyptian language for "black or blackness" (1988, p. 193). Hence the idea that Ham's name contributed to his later racialization. However, David M. Goldenberg in his exhaustive study of the subject, The Curse of Ham: Race and Slavery in Early Judaism, Christianity and Islam, refutes the contention that Ham originally meant "heat" or "black" or is related etymologically to the Egyptian word Kemi. Goldenberg states: "We don't know when this assumption first occurred, but we begin to see the confusion with the word for "heat" in the first century and with the word for "dark, black" somewhere between the second and fourth centuries" (2003, p. 156).

The Table of Nations in Genesis 10:6 lists Ham as the father of Cush (Ethiopia), Mizraim (Egypt), Put (Libya), and Canaan (Palestine). Thus Ham is identified typologically as the mythical progenitor of prominent groups in northeastern Africa and the Near East. Through these legendary genealogies and his later linguistic "blackening," Ham eventually became the eponymous ancestor of all "blacks" in Africa or of "African" descent (see Sanders 1969 for another view of Hamites).

The Israelites of the first millennium BCE were no strangers to domestic slavery and, as the Hebrew Bible attests, they even claimed to have been the slaves of their neighbors in Egypt. Common though slavery was in the ancient world, Noah's curse drew a distinction between previous types of bondage and the form of Canaanite slavery 
it authorized. Viewed in the context of George Spencer Brown's “first Law of Construction," the Noachic distinction severed the existing space (and forms) of slavery in the ancient world by introducing the concept of a divinely sanctioned, permanent and eternal servitude based on group-descent. In his comparative study, Slavery and Social Death, sociologist Orlando Patterson uses the concepts of "intrusive" and "extrusive" slavery to categorize two modes of social death: the condition or status of "nonbeing" that constitutes the social identity of a slave (1982). Patterson views Hebrew slavery as a "highly intrusive" form of bondage that regarded the slave as the "domestic enemy" or “quintessential enemy within” (1982, p. 40). Patterson's intrusive mode, however, does not adequately account for the role of the counterreligion in determining the nature of Canaanite slavery as authorized and rationalized in the Hebrew Bible. The Mosaic distinction suggests a third modality of slavery that differs significantly in its consequences from Patterson's existential idea of social death. For lack of a better term we will refer to this as the execrative mode because it introduced through Noah's curse the notion of slavery as eternal damnation and enslavement as a kind of spiritual death. Thus, from the viewpoint of the counterreligion and its true/false dichotomy, Canaanite slaves were not merely affronts to the living god or "intruder[s] in the sacred space," as Patterson's intrusive criteria demands, they existed and forever remained outside the Israelite god and the "sacred space" of Israelite religion. It is important to note, however, that not all forms of Israelite slavery fit the Mosaic distinction. Jews enslaved their fellow Jews in accordance with traditions that sanctioned debt-slavery and other types of bondage. Patterson's categorization best fits these forms of Hebrew slavery. The point of the foregoing argument is to distinguish the social consequences of the Noachic 
distinction from those of other forms of slavery, and demonstrate that its rationale lies least in perceptions of ethnic or racial differences and foremost in the Mosaic distinction between believers and non-believers. Again, the underlying premise of this search for the formative roots of racial ideology is that essentialized religious distinctions came first and provided the template for later racialized distinctions. Other biblical sources also support this contention.

Canaan clearly is the target of Noah's opprobrium, a fact that leads most scholars to interpret Noah's curse as a justification for the Israelite practice of enslaving Canaanites. Setting aside the psychological analysis suggested by the inferences of incest and sodomy that haunt the story, I contend its sexual symbolism functions principally to distinguish the religious beliefs and practices of the "counterreligionists" from other Canaanite populations. Leviticus, in the Hebrew Bible, which recounts legendary events after the Israelites' mythical exodus from Egypt, reveals sexuality to be a flashpoint of divine wrath. In this third book of the Torah, god instructs Moses: "After the doings of the land of Egypt, wherein ye dwelt, shall ye not do: and after the land of Canaan, whither I bring you, shall ye not do: neither shall ye walk in their ordinances" (Leviticus 18:3). An impressive list of supposed Canaanite sexual offenses follows, along with stern admonitions to obey god's commandments. Unlike the attitude displayed toward Adam and Eve in Eden, the post-exodus Israelite god seems singularly and inexplicably obsessed with nakedness and threatens to punish his followers, body and soul, for any infractions. The litany of sexual taboos in Leviticus suggests the orgiastic features of Canaanite rites and festivals were severely suppressed among the followers of Moses. These rituals and their use of "graven images" furnished moral and religious pretexts for 
the enslavement of Canaanite cosmotheists. Accordingly, Moses' god sanctioned their bondage and oppression with his blessing: "Both thy bondmen, and thy bondmaids, which thou shalt have, shall be of the heathen that are round about you: of them shall ye buy bondmen and bondmaids" (Leviticus 25:44). In Leviticus 25:46, Moses' god grants his Israelite followers the right to enslave heathens "for ever." This restatement of the earlier Noachic distinction—which substitutes "heathen" for Canaan—emanates directly from the mouth of the monotheistic deity. Being a heathen or non-believer, therefore, meant the possibility of lifelong inclusion in an oppressed class in ancient Palestine. Thus the notion or condition of "heathen" established the precedent for slavery based on group-identity or group-descent, and hence was the forerunner of negro slavery.

Nowhere does the Torah or Old Testament explicitly characterize Canaanite identity or behavior on the basis of race. Sexuality, nudity, polytheism justified the vilification and oppression of Canaanites, not race. Historian William McKee Evans argues Noah's curse was a "family" curse: “... the enslavers and the enslaved were descended from brothers" (1980, p. 17). While Palestinian archeological findings may support McKee's contention that the oppressed were ethnically related to their oppressors, mythic and religious interpretations of these familial relationships present a much different picture. The Israelites in Canaan constructed their national identity through their religious cult and used mythical genealogical schemas to locate and define themselves within existing worldwide networks of cultural and historical relationships. The "universal" god conceived by the Israelites created and governed the world and all its populations, thus the mapping and indexing of the known world and its diverse peoples in the Torah proceeded according to biblical tropology and ideology. From this perspective, 
the "brotherhood" of the sons of Noah (Shem, Ham and Japheth) should be seen as a mythic rather than a genetic fraternity. This is because Old Testament genealogies do not refer exclusively to Jewish lines of consanguinity; they also delineate the divergence of various non-Jewish populations from a Jewish line of descent. This pattern begins with Adam the first male ancestor of all human beings. Adam, the father of the Israelites through his son Seth, is also the father of sons who represent non-Jewish populations. A convention other than strict patrilineal descent operates in the Torah to allow Jewish fathers to sire non-Jewish offspring. The theological premise that informs this genealogical method requires the Israelites to document their historical presence since the creation of human beings, and account for their historical difference from non-Jews over the same course of time. Divergence of non-Jews from the Jewish ancestral line makes this possible. In addition to this pattern of divergence, Old Testament genealogies also reflect a self-conscious pattern of inversion: Karin Andriolo in her insightful paper, $A$ Structural Analysis of Genealogy and Worldview in the Old Testament, explains this process as follows:

By virtue of the covenant, Israel views itself as a unique and special people. Its claim to be God's contract partner, the sole representative of its laws, necessitates modification of the descent system-hence, the process of inversion. Within the general branching from the first ancestor which established the world's population, Israel's special role has to be marked by contrast. While branching continues, Israel remains a trimmed lineage. Just as there is only one people selected to represent God's law, there can only be one son to represent the Jewish lineage in each generation (1973, pp. 1664-1665).

The Jewish god's destruction of humanity through the great flood of the Genesis myth casts Noah in the patristic role of Adam. Accordingly, all human beings are descended from Noah. But not all human beings are Jewish. Shem, Noah's eldest son, continues the line of Jewish descent through his son Arpachshad (Genesis 4:25-26; 
Genesis 5:3-32). But Noah's sons Ham and Japheth diverge from the Jewish descent line. The sons of Ham are Cush, Mizraim and Phut, who are associated with the inhabitants of North Africa and the Southeastern Mediterranean. The sons of Japheth cover the Northern Mediterranean and are viewed biblically as ancestors of the Anatolians, Cyprians, Etruscans and Scythians. Geographic, historic, linguistic, political and ethnic considerations contributed to the configuration of this mythic map and its method for determining degrees of Jewish and non-Jewish kinship. But the concept itself is centered in the covenantal paradigm of Jewish religion. The genealogical distinction is conceived first and foremost as a religious distinction. The contract with god signifies the contrast between Jews and non-Jews. Thus Noah can curse Ham and his descendants through Canaan without cursing his own genetic (spiritual) progeny, and Shem and Japheth can conquer and enslave Canaanites without the taint of (spiritual) fratricide.

The trimming of Jewish descent to a single lineal line posed the problem of how a lineage becomes a nation. Genealogical segmentation solved the problem of tribal filiation and affiliation by structuring Jewish lineal descent through the twelve sons of Jacob. Jacob receives the name Israel from god (Genesis 32:28) and his children become the "children of Israel." The one becomes many and yet remains one. In a single generation, through one male of the Jewish line, the twelve tribes of Israel are born and a family becomes a heterogeneous nation. Andriolo summarizes how the processes of divergence, inversion, and segmentation supported the monotheistic Israelite worldview as follows:

In ideologizing reality, descent and worldview are synchronized. Divergence projects a panorama of the world which is created and presided over by a universal God and which is populated by various peoples whose history, location and ethnicity weave them into a network of relations. Invergence confirms the 
identity of Israel as a representative of God's laws, chosen by him from among the peoples of the world. Segmentation explains how the homogeneous representatives of God's laws grew into the heterogeneous people (1973, p. 1666).

Andriolo's comment helps to illustrate how the counterreligion structurally reinforces the exclusiveness of its religious ideology with the inclusiveness that membership in its polity of belief confers. Thus the god of ancient Israel can be the god of the universe and all mankind (inclusive), without the acknowledgement, consent and participation of any but the chosen (exclusive). To be chosen requires choosing the one god and denying all others. Israel's covenant with god through Moses serves as the synthesis and manifestation of this union. The rite of circumcision, perhaps borrowed from Egypt, signs the contract between god and his people. The spiritual and genealogical compact begins with Adam. With the destruction/recreation of the Genesis flood, the genealogical process continues through the sons of Noah. But the Noachic distinction marks a significant disjuncture in the pattern of lineal divergence. Noah's curse does not just call attention to the lineal divergence of Ham and his descendants through Canaan it also introduces a severe punishment that indelibly and permanently distinguishes this lineage from all others. The mythic execration of Ham, and the fictive map of nations derived from this episode, in time, proved disastrous for people of "African" descent.

The Hebrew Bible embodies literary concepts, idioms and sagas from a literary world that stretches from Africa to India, and from the third millennium BCE to the end of the first century CE (T. Thompson, 1999, p. 284). The biblical view of the human past, therefore, is a spiritual, fictive and allegorical view that has little or nothing to do with actual human events. Hence the terms "biblical history" and "biblical archeology" grossly 
distort and misrepresent "biblical" scholarship. Accordingly, any attempts to explain the curse of Canaan in terms of "biblical history" must also be rejected. The approach to Noah's curse presented here illustrates how it operated as a belief system or ideology in Israel's quest to nationalize itself and its people through its literature and folklore. To see it otherwise is to accept the national myth—including the stories of the Ark, the burning bush, and the fallen walls of Jericho—as an authentic and verifiable account of the birth of a nation.

This search for the ideological roots of "black" identity, antiblack racism, and racialized slavery locates the Mosaic and Noachic distinctions within the contexts of their mythic origins rather than posits for them a precise epistemology and historical pedigree. To do otherwise would reproduce the same errors of analysis and attribution that have been the focus of much criticism in this thesis. Given the xenophobic myths and phenotypic fictions embodied in the social construction of race, it should come as no surprise that key ideological cornerstones in its foundation were fabricated from ancient traditions that more often than not have been misinterpreted and misappropriated. Despite such dubious origins, however, the Mosaic and Noachic distinctions proved to be profoundly effective in their social transformations of the ancient world. What was more or less a localized phenomenon suddenly internationalized and dramatically intensified when these ideologies shaped and influenced Christian and Islamic thought in the first millennium CE. It is during this remarkable period that the counterreligion proliferated, achieved imperial power and effectively relegated pagan religions to the fringes of the emerging world system. 
Through Egyptologist Jan Assmann's theory of the cultural construction of difference we considered how the true/false dichotomy introduced by the counterreligion furnished a basis for the development of a prototypic racism: a racism of faith, a racism without race. Labeled the Mosaic distinction by Assmann, the distinction between true and false severed the existing religious space of cosmotheism, divided humans on the basis of believers and nonbelievers, and opened the door to successive and excessive theological bifurcations. Assmann sates: "Once the distinction is drawn, there is no end of reentries or subdistinctions. We start with Christians and pagans and end up with Catholics and Protestants, Calvinist and Lutherans, Socinians and Latitudinarians, and a thousand more similar denominations and subdenominations" (1997, p. 1). In this analysis of the social construction of race we start with Judaism and will continue with Christianity and al-Islam: two major monotheistic "reentries or subdistinctions" that developed in the first millennium CE. 


\section{EARLY CHRISTIANITY}

Christianity, like Judaism, is grounded in the monotheistic tradition of the Hebrew Bible and the cosmotheistic traditions of Africa and the Mediterranean world. Although it posits for itself a new beginning with a New Testament, its revelation depends on spiritual beliefs and practices that came before it. Hence it is possible to speak of a Christianity Before Christ, as Afrocentric historian John G. Jackson does in his book of that name (1985). Jackson does not address the Judaic roots of Christianity, but concentrates instead on the pagan cults of various crucified saviors (Osiris, Bel, Prometheus, Krishna) whose mythology precedes the development of Christian belief. With this literary and iconographic evidence Jackson shows how the Christ-figure fits within a pre-Christian cosmotheistic typology and tropology. British Afrocentrist and autodidact Gerald Massey (1829-1907), in Ancient Egypt the Light of the World, lists 271 tenets of Egyptian religion he argues were Christianized in the gospels of the New Testament. Massey's complex analysis of Christianity's pagan roots distinguishes the mystical Christ from the historic Jesus of Nazareth and delineates the separate paths of the two traditions and their convergences (1907a, pp. 907-914). Afrocentric scholar Charles Finch, following Massey, also posits the birth of Christianity within a predominantly Egyptian context. In Echoes of the Old Darkland: Themes from the African Eden, Finch concludes that the cult and funerary rituals of the Egyptian god 
Osiris furnished Christianity with the conceptual framework and iconography upon which much of its savior-god's identity and appeal was established (1992, pp. 179-216).

Historian David Fideler, in Jesus Christ Sun of God, links Christianity to the teachings of the legendary Greek hero Orpheus (1993). Orpheus' followers, the Orphics, believed the Greek god Dionysus—who was slain, dismembered and resurrected from the dead—rose to heaven. According to Fideler, this popular pagan belief facilitated Greek conversion to Christian doctrine: "The personal identification with a slain and resurrected savior divinity was out of place in the Jewish world; amongst the Greeks it was commonplace and readily acceptable" (1993, pp. 173-174).

Jackson, Massey, Finch and Fideler's comparative studies of myth and religion demonstrate how Christianity developed in part through the continuing engagement of Jewish religious thought with so-called pagan beliefs commonly held in the ancient world in the first century CE. While the Christian tradition readily acknowledges its Judaic roots, it does not accept or admit any connection to paganism. Christian doctrine posits the embodiment and personification of its savior-god "Christ" in Jesus of Nazareth, a legendary Palestinian Jew whose divine birth revealed a new religion and inaugurated a new era and covenant with the god of the Hebrew Bible. Yet the core components of this doctrinal statement, which purportedly is based on "historical' rather than "mythical" events, reflect and recapitulate the common pagan heritage of the ancient world. Virgin birth in a stable or cave on or near the winter solstice (Christmas), crucifixion and resurrection, and commemoration by Eucharistic rites—elements commonly attributed to the cult of Jesus Christ—also characterized the earlier cults of the cosmotheistic saviorgods cited above by Jackson (1985, pp. 39-41). These two traditions- - the prehistoric and 
pagan "Christ" before Christianity and the pseudo-historic Jesus of Nazareth—merge almost seamlessly into the singular sacred tradition that constitutes the Christian faith and its apostolic creed. This conflation of pagan myth and Christian history takes place in the New Testament. Like Judaism, Christianity defines, authorizes and transmits its system of beliefs and practices through a body of sacred texts.

Ironically, the "sacred texts" of the New Testament depict Jesus not as the founder of a new religion but as an orthodox (literally, "straight thinking") Jew. Given his identification with the Jewish Messiah, Jesus could be seen as the leader of a sectarian movement within Judaism rather than a cult movement outside it. Sectarian movements occur in times of chaos or distress to renew or uplift existing spiritual beliefs and traditions. A sect (internal schism) becomes a cult (distinct religion) when its membership breaks completely with the principal articles of faith that distinguish the founding religion's ideology or creed. In the first century CE, Judaism was rife with competing and mutually hostile sects (Essenian, Pharisaic and Sadduccean). Despite different interpretations of Mosaic laws and customs, these sects remained essentially "Jewish" by adhering to the strict monotheism of Jewish tradition (Armstrong, 1993; Wilson, 1992). The followers of Jesus' Jewish sect, however, eventually created the Christian cult through the introduction and adoption of two important theological distinctions: belief in the Trinity (God the Father, God the Son and the Holy Ghost); and the related notion that Jesus was the Son of God or god made flesh. These distinctions severed the strict monotheistic space of Judaism and marked the separation of the Christian church from the Jewish synagogue. 
Whether Jesus' Jewish sect became a Christian cult during his life or in the decades following his death remains the subject of much debate. Jesus, however, never wrote a word of the gospels, and those who did relied on oral traditions that were decades old before they were compiled and written down. The literary conception and construction of Christianity therefore rests with those who never knew Jesus in the flesh (Wilson, 1992, p. 31). Many scholars, including Gerald Massey, Karen Armstrong and A. N. Wilson, believe the Christian writer Paul, a Hellenized Jew, "invented" Christianity. Paul's fingerprints can be seen all over the liturgical and canonical construction of the Christian Church. A. N. Wilson asserts: "The gospels of Mark and Luke, and to a lesser extent that of Matthew, are written under the heavy influence of Paul's ideas" (1992, p. 7). A diasporan Jew, Paul was a native of Tarsus, a cosmopolitan and Hellenized city in Cilicia, Asia Minor (modern-day Turkey). After his conversion to Christianity, Paul carried his version of the Christian message or "good news" to the port cities of Asia Minor, to Greece, and eventually to Rome. The Jews in his audiences, most of whom were diasporan like him, would have identified Paul's Jesus with the Jewish Messiah. Whereas, the Greeks in his audiences, who were far greater in number, would have seen Paul's Jesus as a demigod or divine incarnation, in accordance with their cosmotheistic ideas and beliefs.

In his evangelical drive to universalize the Jewish sect and attract non-Jewish converts, Paul discarded the Judaic practice of circumcision and Jewish dietary restrictions. This action alienated many of Jesus' Jewish followers. But Paul's belief in the "Gospel of Christ," a phrase he often repeated, authorized a new covenant with god, one that could be signed and ratified through baptism and Eucharistic rites (Wilson, 1992, 
p. 18). Thus it can be argued that Paul, with his Jewish origins and wide-ranging knowledge of Greek literature and culture, served as a link between Judaic and Hellenic worldviews, and that he ultimately fused those worldviews in the enduring icon of Jesus Christ—whose very name represents the merger of Jewish (Yeshu) and Greek (Christos) cultures. The singular trope, Judeo-Christian, signifies the union of these essentially nonWestern ideologies that profoundly influenced the construction of modern Western identity and the identities of those under Western domination.

Christianity posits its tradition as a continuation of the counterreligion introduced by the Mosaic distinction and its true/false dichotomy. Hence the authors of the New Testament, of whom Paul was the most prolific, constructed their gospels according to the literary traditions and conventions of the Hebrew Bible, and conceived their texts as the next chapters in the "history" of the "true" god and "his" covenant with "his" chosen people. Although the Gospel of Mark (70 CE) is believed to be the earliest written account of the life of Jesus, the New Testament begins with the Gospel of Matthew (90 CE) (Armstrong, 1993, p. 80). Matthew opens with a traditional Jewish genealogical line of descent that connects Jesus' ancestry to the patristic lineage of Abraham (Matthew 1:117). This genealogical motif bridges the gap of five centuries or more that exists between the authoring of Hebrew Bible and the New Testament; it also delineates Jesus' Jewish ancestry from Abraham to David and from David to Joseph. By this means Jesus, the Son of God, is given a royal lineage through his human "father" Joseph in accordance with the Jewish messianic tradition. With this mythic preamble, Christianity presents itself as the fulfillment of biblical prophesy and Jewish eschatology despite the fact that Matthew immediately violates Judaism's strict monotheism by introducing the idea of Jesus' 
divine conception and birth (Matthew 1:18-25). The Gospel of Mark lacks this genealogical trope. Moreover, as Karen Armstrong points out in A History of God, "[Mark] presents Jesus as a perfectly normal man with a family that included brothers and sisters. No angels announce his birth or sang over his crib. He had not been marked out during his infancy or adolescence as remarkable in any way" (1993, p. 80).

For Paul and his followers, the gospel of Jesus constituted a new revelation of the Mosaic distinction — the only "true" religion. This new revelation necessitated acceptance of Jesus as the Messiah not in the Jewish sense of a god anointed savior of the Jews, but in the new Christian sense of the spirit of god made flesh whose "historical" death and resurrection constituted a spiritually redemptive act for all humanity. Paul's Epistle to the Romans, which A.N. Wilson regards as one of the most influential books ever written (1992, p. 28), expresses the inclusiveness of his Christian mission in its opening passages:

I am debtor both to the Greeks, and to the Barbarians; both to the wise, and the unwise. So, as much as in me is, I am ready to preach the gospel to you that are at Rome also. For I am not ashamed of the gospel of Christ: for it is the power of God unto salvation to every one that believeth; to the Jew first, and also to the Greek (Romans 1:14-16).

Paul's division of the world between "civilized" Greek-speakers and inarticulate non-Greeks in the first line of this quote reflects a Hellenic view of the ancient world. But the phrasing of the last verse, "to the Jew first, and also to the Greek," maintains the priority and centrality of the Jewish revelation in Christian dogma. Paul's message reflects the tension and frisson between the historical significance of Judaism and the Jews as the chosen people, and his effort to recruit the vastly larger numbers of non-Jews to the Christian faith. As a Jew, Paul saw himself as part of a tribe or nation bound by a 
common law and genealogy. As a Christian, Paul placed salvation above all cultural practices and customs. This message of salvation and eternal life shifted attention from the vicissitudes of this world to the promise of everlasting peace in the next. It often has been claimed that this promise of a reward in heaven for the faithful followers of Jesus influenced many slaves in the ancient world to convert to Christianity (Patterson, 1982, p. 70). But salvation, like baptism, meant redemption from sin not slavery. For Christian slaves this generally meant freedom in the next life rather than manumission in the present one. When Christianity became the official religion of the Roman Empire in the fourth century CE, it continued the existing Roman slave regime without disruption.

Brent D. Shaw, in a critical introduction to Moses Finley's book Ancient Slavery and Modern Ideology, describes "the centrality of slavery to the Christian world order in the Roman Empire" as follows:

It is not just the fact of whatever accommodation was reached between Christianity and slavery (to speak merely of 'accommodation,' however, would surely misjudge the actual relationship), but rather the plain fact that the core message of Pauline and post-Pauline Christianity was calqued on the model of the slave-holding family. The centrality of slavery - with its paradigm of the slaveholding 'lord' at the head of his patriarchal family, and the concomitant image of the 'savage discipline' of the whip—was a critically important template in the development of Christian ideology, especially, it seems, in the last quarter of the fourth century. It was an age of the most intense creation of ideas that were to have a profound impact on the West, not the least on the prevalent theodicy whose origins and development were to be found in the models provided by chattel servitude (Shaw, 1998, p. 51).

Shaw sees slavery as a central metaphor of Christian theology. Patterson, citing J. G. Davies, argues three key words in Paul's theology—redemption, justification, reconciliation—also reveal "the extraordinary role of the slave experience as a metaphoric source" (Patterson, 1982, p. 70). Patterson contends redemption means emancipation from sin; justification symbolizes the slave's manumission and his 
restoration from social death, while reconciliation restores the former slave's membership in the community (1982, p. 70). These three ideas evolve directly from the Christian belief in salvation from sin-the "master concept" that unifies Christian theology (Patterson, 1982, p. 70). Jesus' human sacrifice through crucifixion saves (liberates) his followers from the wages of sin, which is spiritual death. But emancipation from sin means divine enslavement and submission to god through his son Jesus. Divine enslavement—accepting Jesus as Lord and Master—emancipates the sinner from death and rewards him with life everlasting. Patterson concludes his analysis of the slavery metaphor in Christianity with this observation:

Whatever other factors explain Christianity's conquest of the Roman world, there seems little doubt that the extraordinary way in which its dominant symbolic statements and meanings are informed by the experience of slavery was a major contributing factor. For the same reason too, Christianity was to provide institutional support and religious authority for the advanced slave systems of medieval Europe and of the modern Americas (1982, p. 72).

Once Christianity became the official religion of the Roman Empire it became the official religion of a slave society. Moses Finley, using Immanuel Wallerstine's conceptual framework, labels the Roman Empire a "world-empire" and not a "worldsystem," to note its structure was organized politically rather than economically or socially and thus allowed "different labour-regimes and modes of production" to co-exist (1998, p. 147). With this distinction in mind, Finley restricts his analysis of GrecoRoman slavery to Greece, Italy and Sicily. Finley's cautious approach notwithstanding, it is appropriate to state that slavery existed, functioned and flourished for centuries as a religiously sanctioned institution under Christian authority in the Roman Empire regardless of the locale or the mode of production employed. Whether a particular Roman province was a slave society or a society with slaves, Christian authorities did not disturb 
the status quo. Instead, as has been pointed out, Christian exegetes saw in slavery a potent metaphor for their religion's theodicy and theology, and spoke of its abolition in otherworldly rather than worldly terms. Robin Lane Fox in Pagans and Christians summarizes the Christian view of slavery as follows:

On the conduct of slaves, Christian texts were unanimous. The Pauline epistles stated very clearly that slaves must submit, and for most Christian authors their words sufficed. If they were expanded, they were emphasized: slaves must obey their masters as the 'image of God' (1986, p. 297).

Slavery was not determined by race in the Greco-Roman pagan world or in the early Christian culture that supplanted paganism. Race is a modern social construction unknown to the people of late antiquity. Hannaford, referring to texts by Hesiod, Herodotus and Hippocrates states:

Close examination of these early Greek works, however, uncovers no assumptions about the major divisions of mankind based upon the idea of biologically transmitted characteristics, and hence no theoretical notion of biological similarity or dissimilarity except in a crude humoral sense. There were no physically differentiated types, no word that approximates or resembles 'race' (1996, p. 20).

Early Christians accepted the Hebrew Bible's creation story of Adam and Eve as evidence of the singular origin of the human family. Thus the Christian position emphatically stated by Paul was that God: "hath made of one blood all nations of men for to dwell on all the face of the earth ..." (Acts 17:26). Like their pagan predecessors and contemporaries, early Christians believed the phenotypic (outward physical) characteristics of diverse human groups were caused by different environmental conditions. Frank Snowden in Blacks in Antiquity states: "The first anthropological contrast of blacks and whites_-Thracians and Ethiopians_-is found in Xenophanes, a contrast that was later to appear frequently in a Scythian-Ethiopian commonplace and in 
the environmental theory of the origin of racial differences" (1970, p. 25). Snowden's use of the term "racial differences" is anachronistic and highly misleading in this context. The ancient environmental theory cited by Xenophanes, Herodotus, Pliny and a host of widely known classical writers accounted for differences in physical appearance without the suggestion or theory that immutable or inherent biological differences separated or distinguished human groups. Thus the term "Ethiopian"—used generically in the GrecoRoman world to refer to dark-skinned people—means, "burnt face" in Greek, and suggests a derivation from the idea that dark skin is caused by the sun (Hannaford, 1996, p. 19). The environmental ideas embodied in the Scythian-Ethiopian trope found their way into early Greek art in the form of Janiform vases that depicted and juxtaposed the heads of blacks and whites to illustrate and contrast differences in their facial features and skin color (Snowden, 1970, pp. 24-25). According to Snowden, this Scythian-Ethiopian formula also "appears in various forms in early Christian writings," to dramatize the spread of Christianity to all corners of the known world (1970, pp. 196-197). Using this trope, Christians proclaimed the global diffusion and universality of their faith. But it was the Ethiopian component of this formula that held the most significance in early Christian exegesis and symbolism. The New Testament perhaps best illustrates the centrality of Ethiopians to early Christian exegesis. Acts 8:26-40 relates the conversion and baptism of an Ethiopian eunuch who was a prominent figure in the government of the Candace (Queen) of Ethiopia. This Ethiopian was the first Gentile to convert to Christianity, and thus allegorically represented the first successful evangelizing of the faith to non-Jews and the very establishment of the Christian church. Ironically, this conversion of the Ethiopian eunuch occurred before Paul's legendary epiphany and conversion on the road 
to Damascus. Hence it can be said that an African accepted the gospel of Jesus before the purported "inventor" of Christianity received his calling to the faith.

Christians also were familiar with various Jewish traditions concerning Ethiopians. The numerous references to "black" persons in the Old Testament and in rabbinic commentaries, including those related to Ham, demonstrate the pervasive "black" presence and influence in the Near East and constitute important sources for the abstract and symbolic use of "blackness" in Christian literary motifs. David Brion Davis in Slavery and Human Progress, citing Ephraim Isaac, notes that:

... in some Jewish sources both the children of Shem (including the Israelites) and the children of Ham [Cush, Mizraim, Put and Canaan] were described as black; the first as 'black and beautiful', the latter as 'black like a raven.' Rabbis spoke of the beauty of Moses' Kushite (or Ethiopian) wife, of the black Queen of Sheba, and of Solomon's Kushite scribes. The famous passage in the Song of Songs "I am black but beautiful, O ye daughters of Jerusalem," appears to have read, in the Hebrew and earlier Greek versions, "I am black and beautiful" (author's italics) (Davis, 1984, p. 36).

Byron (2002), Davis (1984), and Snowden (1970) credit the influential Christian writer Origen (185?-254 CE), who was head of the catechetical school in Alexandria in the third century $\mathrm{CE}$, with establishing an allegorical framework central to early Christian exegesis based on the Jewish traditions cited above. Origen-who Snowden describes as a "pioneer in exegesis and in textual criticism of the Bible"- - used those themes and motifs to illustrate both the struggle and victory of the Christian Church in universally evangelizing the faith, and to present a complex imagery of spiritual blackness and whiteness (1970, p. 198). Accordingly, Origen depicted Moses' marriage to an Ethiopian wife as symbolically prefiguring the union of the Jewish Torah (Law) with the Gentile nations. For Origen, the bridegroom (Moses) personified the transmission of the Mosaic distinction and Jewish monotheism to the "black bride," who symbolized the universal 
(or Catholic) church and its Gentile congregation (Davis, 1984, p. 36; Snowden, 1970,

pp. 198-199). Similarly, Origen's commentary on the Queen of Sheba's statement "I am

black and beautiful" illustrates his hermeneutic and discursive use of this tropology to explicate Christian doctrine:

Moreover we ask in what way is she black and in what way fair without whiteness. She has repented of her sins; conversion has bestowed beauty upon her and hence she is sung as "beautiful." But because she is not yet cleansed of all the uncleanness of her sins nor washed unto salvation, she is said to be "black" but she does not remain in her black color-she becomes white. ... But if you repent, your soul will be "black" because of your former sins, but because of your penitence your soul will have something of what I may call an Ethiopian beauty (Snowden, 1970, p. 199).

Implicit in Origen's statement is the Christian belief in the fallen state of humanity into sin. Thus Origen sees all humans as "black" or sinful by nature. They become "black and beautiful" upon repentance, and white upon salvation. This whitening of blackness as an allegory for salvation became a common motif in Christian literature, frequently repeated by Cyprian, Jerome, Augustine and a host of early fathers of the Latin Church (Byron, 2002). The color-coding of this allegory of sin and salvation, while nonracial in its inception, established a paradigm that proved disastrous for "black" people with the advent of the African slave trade and the social construction of race theory and antiblack racism in Europe. The Christian convention of depicting demons with "black" or Ethiopian features ultimately figured into the demonizing and dehumanizing of "black" people in later Muslim and European thought. Davis argues that this "color symbolism is derived in part from astrology, alchemy, Gnosticism or various forms of Manichaeism" (1984, p. 37). Regardless of the sources or combination thereof, it is clear Christian writers established a religious convention based on color that would remain decisive in human relations for countless generations. It is crucial to the proper 
understanding of this allegorical framework to grasp its religious and its proto-racist significance. The failure to do so results in an inability to recognize how these early abstract and symbolic forms of thought led to the development of the concrete idioms of modern racism. The slippery slope that separates the thin line between proto-racism and modern racism can be difficult to negotiate. Snowden's comments are illustrative of this point:

The early Christians in their view of the Ethiopian continued the Greco-Roman tradition not only in sentiment but also in language and imagery. For Christian writers of the first centuries after Christ, it made no difference whether one was as racially different as the Scythian or the Ethiopian; of no importance was the region of the world or the cultural group from which a man came. Color was inconsequential; in fact, we have seen that they regarded as black all men who had not been illumined by God's light and considered all men, regardless of the color of their skin as potentially Christians (1970, p. 205).

Snowden, in his emphasis on the symbolic aspects of this form of early Christian ethno-political rhetoric, fails to consider the social consequences of these ideas on darkskinned peoples within and without the early Christian world. Gay L. Byron provides an insightful critique of Snowden on this point. She also makes clear that the uses of these tropes of blackness that involved Egyptians/Egypt and Ethiopians/Ethiopia served as shorthand or iconic devices to define sexual threats, vices and sins, as well as the basic binary of insider/outsider (2002).

As the self-proclaimed heirs of the Mosaic distinction, Christians ratified and reified the true/false dichotomy in religion and posited and proselytized their creed as the only "true" faith. Thus the principal distinction that mattered to early Christian theologians was whether one was a believer or non-believer. In this primary sense, a person's skin color was irrelevant. But in daily social interactions this color-coding of sin, vices, and sexual threats must have had an impact on ethnic relations. By the fourth 
century CE, Christianity was firmly established in North Africa. Accordingly, during its formative first four centuries many "Africans" assumed key leadership positions in the Church. For many Christians this development signified the fulfillment of the Old Testament prophecy: "Princes shall come out of Egypt; Ethiopia shall soon stretch out her hands unto God" (Psalms 68:31). For other Christians, those with dark skins, the idea of whitening blackness as a way of removing sin must have posed severe challenges to their acceptance and pursuit of Christian ideals. Once the center of Christian authority shifted from Alexandria to Rome in the late fourth century and Christians achieved political power in the Roman Empire, a dramatic transformation of the ancient world began to take place. Instead of Christians feeling the wrath of pagan rulers, non-believers (pagans and Jews) became the objects of Christian persecution or prosecution for resisting or failing to convert to the new world order (Fox, 1986).

Christian acceptance and canonization of the Hebrew Bible also made them heirs to the Noachic distinction. Few references to Noah's curse, however, are found in early Christian writings. Augustine of Hippo (354-430 C.E.) is a notable exception. Armstrong describes Augustine as "the founder of the Western spirit," and states that: "No other theologian, apart from St. Paul, has been more influential in the West" (1993, p. 119). In Book XVI of his renowned exegetical work The City of God, which was written and serialized from 413-426 CE, Augustine explores the story of Noah and his three sons in some detail. Augustine uses Noah's curse on Ham to present a complex analogy that equates nakedness to the passion of Christ and the entire episode as a fulfillment of Christian prophecy (Augustine, 1987, pp. 422-423). Augustine's discursive gloss makes use of the names of Noah's sons to drive his point home: "Shem, of whom Christ was 
born in the flesh, means 'named.' And what is of greater name than Christ ..." Japheth means "enlargement" and Ham means "hot" (1987, p. 422). For Augustine, Ham, as the middle brother, is neither Jew (Shem) nor Gentile (Japheth), but represents: "the tribe of heretics, hot with the spirit, not of patience, but of impatience, with which the breasts of heretics are wont to blaze, and with which they disturb the peace of the saints" (1987, p. 422). Where Shem represents the Jewish line of descent and the Christian theological lineage through Jesus, and Japheth the "enlargement" of the Christian congregation through the conversion of the Gentiles, Ham remains the "hot-headed" heretic, the proverbial outsider whose intransigence marks him and his work or fruit (his son Canaan) as cursed. What follows in Augustine's analysis is an explicit endorsement of Canaan's enslavement in an allegorical sense: "But the wicked brother is, in the person of his son (i.e., his work), the boy, or slave, of his good brothers, when good men make a skilful use of bad men, either for the exercise of their patience or their advancement in wisdom" (Augustine, 1987, p. 423). Here, Augustine suggests that the example offered by the enslavement of Ham's descendants furnishes an opportunity for Christian meditation and enlightenment. More importantly, however, the Noah scenario foreshadows for Augustine events that led to the manifestation of Christ, and the establishment of Christian Church as the City of God (1987, p. 423).

In Book XVI, Augustine also comments on the genealogical mapping of the world according to the various lineages established by the sons of Noah. This theory, however, did not become a prominent feature in Christian literature until the medieval period. The writings of the Hellenized Jew Flavius Josephus (37?-100 C.E.) served as the principal vehicle through which this genealogical mapping achieved wider significance 
and notoriety in Christian and Muslim thought. Josephus, in his popular work Jewish Antiquities, identified Shem as Asian, Ham as Afroasian and Japheth as Eurasian (Braude, 1997, p. 111). This interpretation of the sons of Noah circulated widely in the Christian and Muslim worlds, but the concept of the three continental divisions of humanity did not gain currency in Europe until the oceanic voyages of Iberian explorers of the fifteenth and sixteenth centuries provided a more realistic view of global and human geography. Afterwards, in conjunction with the escalation of transatlantic slave trade and the rapid colonization of the Americas in the seventeenth and eighteenth centuries, Noah's curse acquired a specific racist meaning and purpose within the new ideological structures that created and supported Eurocentrism and its emerging capitalist systems. Although Josephus' work constitutes a central source from which this concept was disseminated, Muslim scholars deserve much of the credit for preserving and transmitting this tradition during the medieval period. Accordingly, it is to al-Islam and Muslim literary traditions that we now turn to examine their role and contributions in the conceptualization and formation of modern "black" identity. 


\begin{abstract}
AL-ISLAM
Islam constitutes the next major subdistinction in the evolution of the counterreligion. Muslim tradition cites Muhammad ibn Abdallah (c. 570-632), a merchant who became a reluctant prophet, as the person who revealed Islam to the Arabic-speaking people of Southern Arabia in the seventh century CE. Muslims believe Islam is the uncorrupted and restored monotheistic faith of the biblical patriarchs Adam and Abraham. Muslims also believe Muhammad's recitation of the poetry, homilies, and stories that comprise the Quran constitute a direct revelation of the word of god (Peters, 1991, p. 293). Toby Lester's vivid summary of the traditional Islamic view of how Muhammad received and revealed god's words helps to locate his purported revelation in the context of Muslim faith and how that faith is presented as Muslim history:

Muhammad had developed the habit of periodically withdrawing from Mecca's pagan squalor to a nearby mountain cave, where he would reflect in solitude. During one of these retreats he was visited by the Angel Gabriel-the very same angel who had announced the coming of Jesus to the Virgin Mary in Nazareth some six hundred years earlier. Opening with the command "Recite!" Gabriel made it know to Muhammad that he was to serve as the Messenger of God. Subsequently, until his death, the supposedly illiterate Muhammad received through Gabriel divine revelations in Arabic that were known as qu'ran ("recitation") and that announced, initially in a highly poetic and rhetorical style, a new an uncompromising brand of monotheism known as Islam, or "submission" (to God's will). Muhammad reported these revelations verbatim to sympathetic family members and friends, who either memorized them or wrote them down (2002, p. 117).
\end{abstract}


Muslim traditions record Muhammad's recitations as having occurred over a period of twenty-two years, from 610 to 632 C.E., and that these recitations were "finally assembled or collected" from various sources, some recollected and some written, no more than fifteen years after the Prophet's death" (Peters, 1991, p. 293). F. E. Peters describes the compilation of the Quran as follows:

The Quran as we now possess it is arranged in 114 units called suras connected in no obvious fashion, each bearing a name and other introductory formulae, of greatly varying length and, more appositely to our present purpose, with little internal unity. There is no narrative framework, of course, and within the unconnected suras, there are dislocations, interpolations, abrupt changes of rhyme and parallel versions, a condition that has led both Muslim and non-Muslim scholars alike to conclude that some of the present suras or sections of them may once have been joined to others ... Nor do we know the aim of the persons who arranged the suras in their present order, which is, roughly (the first sura apart), from the longest to the shortest. They are not, in any event, placed in the order of their revelation, as everyone agrees. (1991, p. 297).

The stories surrounding the compilation of the Quran, however, are both confusing and contradictory. Instead of there being only one account of the Quran's final compilation, there are numerous traditions involving several personages who were contemporaries or successors of Muhammad. Such accounts cite the involvement of Abu Bakr, Umar, and Uthman, men who served as Caliphs (successors to Muhammad and temporal leaders of the Muslim community); Hafsa, the daughter of Umar; Zaid ibn Thabit, the former secretary of the Prophet; and other Companions of the Prophet (Warraq, 1998a, p. 13). All existent traditions agree that the Quran was collected from human memory and "from pieces of papyrus, flat stones, palm leaves, shoulder blades and ribs of animals, pieces of leather and wooden boards" and then copied on "sheets or leaves" (Warraq, 1998a, p. 13). As many as fifteen different primary codices and a number of secondary ones eventually emerged from this process, a situation that resulted 
in an order from Uthman (the third Caliph) to destroy all other texts but his own (Warraq, 1998a, pp. 14-15). Nevertheless, three systems prevailed: "those of Warsh (d. 812) from Nafi of Medina, Hafs (d. 805) from Asim of Kufa, and al-Duri (d.860) from Abu Amr of Basra" (Warraq, 1998a, p. 16). Of those three, two remain in use in modern Islam: "Asim of Kuf through Hafs" ... "and that of Nafi through Warsh" (Warraq, 1998a, p. 16). The number of early versions of the Quran and the struggles of the followers of Islam to reconcile what were often contradictory accounts and texts undermine any efforts to assert the singularity and consistency of Muhammad's revelation and the manner in which it was recorded and passed down. Despite this fact most Muslims and some nonMuslim scholars still accept and rely on these traditions uncritically and without questioning their premises and provenance. Similar to the way fundamentalist Christians regard the gospels, Muslims claim and believe their holy book the Quran, the Sira (the biography of the Prophet) and the various Hadith (traditional stories told about the life of Muhammad and his Companions) contain eyewitness accounts of every aspect of the life of Muhammad. The following quote cited by Ibn al-Rawandi from a "contemporary introduction to Islam aimed at young people" illustrates this point:

The life of Muhammad is known as the Sira and was lived in the full light of history. Everything he did and said was recorded. Because he could not read and write himself, he was constantly served by a group of 45 scribes who wrote down his sayings, instructions and his activities. Muhammad himself insisted on documenting his important decisions. Nearly three hundred of his documents have come down to us, including political treaties, military enlistments, assignments of officials and state correspondence written on tanned leather ... Within a few decades of his death, accounts of the life of Muhammad were available to the Muslim community in written form. One of the earliest and most famous biographies of Muhammad, written less than (a) hundred years after his death is Sirat Rasul Allah by Ibn Ishaq (2000, pp. 89-90). 
Despite the tone of authority and verisimilitude with which the above passage presents its historical case for the documentary evidence pertaining to the life and deeds of Muhammad, none of it can be taken as factual. Ibn Ishaq did produce the earliest known biography of Muhammad, but he was born about $717 \mathrm{CE}$, eighty-five years after Muhammad's death, "and would have reached his teens only as much as one hundred years after the events he affects to have portrayed" (al-Rawandi, 2000, p. 91). Moreover, no copies of Ibn Ishaq's Sira exist in its original form nor has it been preserved as a single work. Instead, only a redacted form survives, based on the editorial work of Ibn Hisham (d. 833), who was born in Egypt, and who removed from the text "things which it is disgraceful to discuss, matters which would distress certain people; and such reports as al-Bakka'i told me he could not accept as trustworthy" (cited in al-Rawandi, 2000, p. 91). Other works by other early Islamic scholars and historians are equally problematic. The authenticity of hadith, or books of tradition, collected by al-Bukhari (d. 870), Muslim ibn al-Hajjaj (d. 875), Ibn Maja (d. 887), Abu Dawud (d. 889), al-Timidhi (d. 892), and al-Nisai (d. 915) have been subjected to close analysis and found to be highly questionable by a number of scholars (Warraq, 2000a, p. 37). It is from such works, however, that the traditional paradigm of Islam and Islamic studies is derived. These sources suggest Muhammad was born in Mecca circa $570 \mathrm{CE}$ to a poor but respected clan, the Banu Hashim of the Quraysh tribe, at a time when South Arabian civilization was in a state of turmoil. In the north of the region, the Christian Byzantine Empire centered in Constantinople waged a centuries-old war with the Zoroastrian Persian Empire. In the south, Abyssinian-led Yemenites threatened the independence of the Hijaz, the stony valley between two mountains near the coast of the Red Sea where 
Mecca was located. Islamic traditions state that pre-Islamic Mecca was an important depot on the spice and incense trade route that connected South Arabian and Indian Ocean trade with the civilizations of North Africa and the Mediterranean world (Aslan, 2006, p. 27). Those sources also cite Mecca as the economic beneficiary of regular pilgrimage traffic to the Kabah, a sacred shrine, which, at that time, in addition to its famous Black Stone (possibly a meteorite), purportedly contained an image of the moongod Hubal and was a center for the worship of the three "pagan" goddesses (Brockelmann, 1960, p. 12). Patricia Crone in her book, Meccan Trade and the Rise of Islam, challenges both of these traditions, however, and argues:

Mecca was not located on the incense route, still less at the crossroads of all the major routes in Arabia ... The site was barren, devoid of a fertile hinterland except for Ta'if, ill-equipped for maritime trade, and much too far away for a caravan trade with Syria of a kind that the sources describe (Crone, 1987, p. 194).

Such geo-historical controversies notwithstanding, Mecca and South Arabia did constitute a minor crossroads of religious faiths. Judaism entered the Saudi Arabian peninsula along the major trading routes, much like it had penetrated North Africa. Many of the first Christians in the region came from Jewish synagogues and communities after the gospel of Jesus spread throughout the Jewish diaspora. Much of the Christian influence in South Arabia, however, came from across the Red Sea via Abyssinia (Ethiopia) or from Yemenite Christians to the south. In Mecca, in particular, Judaism and Christianity were practiced and represented by a small minority of its citizens; the vast majority of Arabs still followed the traditional Arab pagan religion (Aslan, 2006).

Tradition has it that Muhammad eventually ran afoul of his fellow Meccans due to his efforts to reform the local religious practices. Under pressure from his enemies, he fled into exile in Medina, a nearby Arab city, where he and his followers dedicated 
themselves to winning over the Arab tribes to the Islamic faith through conversion and conquest. Mohammad's migration to Medina constitutes an epochal event in the Islamic faith. According to tradition, his exile from Mecca marked the official establishment of the Muslim community (umma) and the politicization of Muhammad's leadership. Consequently, the Islamic era begins in $622 \mathrm{CE}$ with Muhammad's migration, known as The Hijra (Flight), rather than his birth year or the year the faith was first revealed (Armstrong, 1993, p. 155; J. A. Williams, 1962, pp. 69-75).

According to various hadith, Muhammad acquired a smattering of knowledge of Christianity in Mecca and a much better familiarity with Judaism in Medina. Armstrong argues that Arabs both respected and resented the two monotheistic faiths that some among them considered "superior to their own traditional paganism" (1993, p. 136). Inspired by Judeo-Christian doctrine, and by earlier Arab monotheists known as hanifs, Muhammad, tradition says, presented his religious vision as a continuation of the "Abrahamic" tradition. The biblical patriarch Abraham—claimed by Jews and Christians as the ancestral founder of their faiths—is accorded the same role in Islam. Muslims recognize and venerate Abraham as both the purported first prophet of Islam and the ancestor of the Arab people. I. Ephal notes: "According to the Bible, Ishmael the son of Abraham and Hagar was the ancestor of certain nomadic tribes who dwelt in the deserts between Palestine and Egypt and North Arabia" (1976, p. 225). This genealogical tradition, recorded in Genesis 25:13-16 and 1 Chronicles 1:29-31, follows the Jewish lines of invergence and divergence previously discussed. In this case, the line of descent from the (Jewish) father Abraham remains Jewish through his son Isaac and becomes the non-Jewish ancestor of certain nomadic groups through Ishmael, Isaac's brother. Ephal 
dates this tradition that links Israel and these desert tribes to the second millennium BCE (1976, p. 226). The term "Arab," however, does not appear in any biblical genealogy. Ephal suggests that "Arab" was the term certain nomads devised to designate themselves (1976, p. 228), and that Arabs became associated with the "Sons of Ishmael" not on the basis of a genealogical relationship but simply through the generalized notion that they were desert-dwellers (1976, p. 232). Ephal argues that the "Arab" designation originally applied to the populations in the northern deserts near Palestine and not to the inhabitants of Southern Arabia, and cites later traditions that distinguish the two groups:

The classical Arab genealogies, formulated during the first century of Islam, divide the inhabitants of the Arabian peninsula into two distant groups: those to the north, descended from 'Adnan, who claimed to be the son of Ishmael, and those of the south, descended from Quathan (to be identified with the biblical Joktan), descendant of Shem, the son of Noah (see Gen. 10:1, 21, 25-29; 1Chron. 1:4, 17-23) (1976, p. 234).

Judaic and Christian biblical traditions entered South Arabia generations before the birth of Muhammad and were widely known to the Arab populations of Muhammad's time. These Judeo-Christian doctrines and beliefs clearly inspired and influenced the development of Islam (Armstrong, 1993; Peters, 1991; Reinking, 2005). It is from their identification with and acceptance of biblical sources that Muslims began to define their belief system as a continuation of the Mosaic distinction and its establishment of the "true" religion. Accordingly, the Quran iterates in its own voice and from its own monotheistic perspective biblical stories and traditions that explain and support its teleology, its eschatology and its authority to present Islam as the latest revelation of god's word and Muhammad as god's prophet. Much like Moses rebuked the Jews for their lapse into worshipping the Golden Calf, Muhammad purportedly exhorted the Arabs to forsake their cosmotheistic conceptions of Allah and submit and conform to a strict 
monotheism. Hence Muslims do not regard Islam as a new faith but as the restoration and continuation of the faith revealed by Allah first to Abraham, Moses and Jesus, and finally to Muhammad. Armstrong notes: "The Koran teaches that God had sent messengers to every people on the earth: Islamic tradition says there had been 124,000 such prophets, a symbolic number suggesting infinitude (1993, p. 152). The following passage from the Quran (2:136) illustrates this belief:

We believe in God, and in that which has been sent down on us and sent down on Abraham, Ishmael, Isaac and Jacob, and the Tribes, and that which was given to Moses and Jesus and the Prophets, of their Lord; we make no division between any of them, and to Him we surrender.

From the above example it can be seen that Muslims adopted the Judaic prophetic tradition and used it to authorize an Islamic religious movement closely modeled on Judaism. According to Islamic traditions, after the Jews in Medina rejected and mocked Muhammad's interpretation of biblical prophecies and his spiritual leadership, he declared the independence of Islam, and in January 624 commanded his followers "to pray facing Mecca instead of Jerusalem" (Armstrong, 1993, p. 155). Muhammad purportedly then established what has come to be known as the "five pillars" of Islam, which stressed the Arabic character of the religion. Much of Islam's organizing genius is revealed in the simplicity of this creed: First, Muslims ("those who submit") are required to profess: "there is no God but Allah, and Muhammad is the Prophet of Allah." Second, believers are required to pray five times a day. Third, all believers are obliged to provide support of the poor. Fourth, Muslims are expected to endure an annual thirty-day fast called Ramadan, during which no food or drink is consumed from sunrise to sunset. And fifth, the faithful are required to undertake a pilgrimage to Mecca at least once in their lifetimes if they possess the means to do so (Aslan, 2006, pp. 145-155). In a further 
departure from Judeo-Christian traditions, Muslims also preached the equality of the sexes and introduced in the Quran legal rights for women including inheritance and divorce. Armstrong states: "Western women had nothing comparable until the nineteenth century," and argues that Islam "was later hijacked by the men, who interpreted texts in a way that was negative for Muslim women" (1993, p. 158).

According to the Quran, Muhammad viewed Christians and Jews as having fallen into error regarding the hanifiyyah, the pure religion of Abraham. Muslims accept Jesus as a great prophet and teacher, but categorically reject the idea of the Trinity, and Jesus' supposed divinity, as blasphemous. Muslim traditions indicate Muhammad viewed biblical episodes like that of the Golden Calf in Exodus as historical evidence of Jewish impiety and intransigence. Yet the refusal of the Jews of Medina to recognize him as the prophet of god brought "his whole religious position into question" and threatened his spiritual authority (Armstrong, 1993, p. 154). Moreover, according to the traditional accounts, Medina Jews eventually formed a military alliance against Muhammad with the Meccans. A series of bloody holy wars supposedly followed during which Muhammad's Jewish enemies were decimated. Various traditions indicate that it was during this period that many Arab tribes converted to Islam, and that in 630 a victorious Muhammad entered Mecca with an army of Muslims after the bloodless surrender of the Meccan forces. Islamic tradition holds that Muhammad then removed the pagan icons from the Kabah, the House of Allah, rededicated the site to Islam, and incorporated the tradition of hajj or pilgrimage to the shrine as the fifth pillar of the faith. Muhammad thus furthered strengthened the appeal of his Islamic creed by preserving important elements of traditional pre-Islamic Arab beliefs. By the following year $(631 \mathrm{CE})$, as tradition would 
have it, most of the Arabian Peninsula had come under Muhammad's authority. Various accounts also indicate that at height of his career as a religious reformer, Muhammad did not envision extending his message to non-Arabs and saw Islam as the Arabs' religion. Armstrong notes:

Nobody in the new empire was forced to accept the Islamic faith; indeed, for a century after Muhammad's death, conversion was not encouraged and, in about 700, was actually forbidden by law; Muslims believed that Islam was for Arabs as Judaism was for the sons of Jacob. As 'the people of the book' (abl al-kitab), Jews and Christians were granted religious liberty as dhimmis, protected minority groups. When the Abbasid caliphs began to encourage conversion, many of the Semitic and Aryan peoples in their empire were eager to accept the new religion. (1993, p. 159).

The traditionally authorized versions of Muhammad's life state that his sudden death on 8 June 632 precipitated a crisis among his followers, as no provisions had been made for a successor (Aslan, 2006, p. 110). The lack of a clear heir or charismatic figure to lead the followers of Islam threatened to unravel the fragile alliance of Arab tribes that had been forged by the Prophet. A solution purportedly was found in the appointment of Abu Bakr as Successor of the Prophet (Khalifa: Caliph). Abu Bakr, however, did not receive the support of all the tribes. Tradition records two years of bitter warfare before his authority was fully established in Medina. To quell further dissension and reunite the tribes, Caliph Bakr and his successor Caliph Umar launched a series of campaigns against the Byzantine and Persian empires. These foreign wars resulted in the conquest of Damascus (635), Egypt (639), Persia (640), and constituted the first successful stages in the establishment of a global Islamic empire (Brockelmann, 1960, p. 525; J. A. Williams, 1962, p. 81).

In presenting the broad outline of key points in the traditional and authorized history of Islam, I have had to qualify nearly every sentence by stating that such and such 
is known "according to tradition." None of these events cited above can be verified by any sources other than the Quran, the sira, and the hadith. However, most scholars agree that the sira and hadith are not independent of the Quran and mostly rely on it for their content. As Henri Lammens points out: "The Koran provides the only basis for the sira" (1910, p. 169). Coupled with the fact that the primary use of hadith (whether some predate the Quran or not) is in interpreting and embellishing the verses of the Quran, what we are left with are sources for the life of Muhammad and the origins of Islam that are self-referential and lacking in outside corroboration. The degree to which this circular process has unfolded in the creation and authorization of Islamic doctrine is evident in this comment about the lack of historical material available in the Quran from Michael Cook:

Taken on its own, the Koran tells us very little about the events of Muhammad's career. It does not narrate these events, but merely refers to them; and in doing so, it has a tendency not to name names. Some do occur in contemporary contexts: four religious communities are named (Jews, Christians, Magians, and the mysterious Sabians), as are three Arabian deities (all female, three humans (of whom Muhammad is one), two ethnic groups (Quraysh and the Romans), and nine places.... Identifying what the Koran is talking about in a contemporary context is therefore usually impossible with interpretation.... Without it we could probably infer that the protagonist of the Koran was Muhammad, that the scene of his life was in western Arabia, and that he bitterly resented the frequent dismissal of his claims to prophecy by his contemporaries. But we could not tell the sanctuary was in Mecca, or that Muhammad himself came from there, and we could only guess that he established in Yathrib. We might indeed infer a more northerly location altogether, on the grounds that the site of God's destruction of Lot's people (i.e., Sodom) is said to me one which those addressed pass by morning and night (Koran 37 verse 137-38) (cited in Warraq, 2000a, pp. 36-37).

Cook's comment casts doubt on the traditions that cite Mecca as the locale where Islam originated and as Muhammad's birthplace. We will return to this point momentarily. First, it is important to address one more issue related to the origins and use of various hadith. Much of Islamic law, customs and history are founded in these 
traditional stories that supposedly originated as the oral anecdotes of the Companions of the Prophet and other eyewitnesses to the events surrounding his life and his revelation. The hadith thus serve as appendices or addenda to the Quran in that they address issues important to Muslims that the Quran does not, particularly in the matter of Islamic law. But even devout Muslims are forced to admit that over time the chain of transmission, or isnad that is supposed to authenticate such accounts:

... grew longer and more convoluted, so that in less than two centuries after Muhammad's death, there were already some seven hundred thousand hadith being circulated throughout Muslim lands, the great majority of which were unquestionably fabricated by individuals who sought to legitimize their own particular beliefs and practices by connecting them with the Prophet. After a few generations, almost anything could be given the status of hadith if one simply claimed to trace its transmission back to Muhammad (Aslan, 2006, p. 67).

In the ninth and tenth centuries Muslim scholars made a "concerted effort" to evaluate, eliminate and authenticate hadith, but one must imagine what standards and criteria were used to tackle such a complicated, convoluted and intentionally deceptive body of literature (Aslan, 2006, p. 68).

A new paradigm of Islamic studies, one that differs drastically and remarkably from the established and official religious history of Islam, has emerged in recent years. Some of this new revisionist scholarship was influenced by the methods and theories developed by John Wansbrough in the 1970s and 1980s. Wansbrough's research generated a firestorm of controversy and criticism when he claimed, "neither the Koran nor Islam is a product of Muhammad or even of Arabia” (Berg, 2000, p. 494). Wansbrough brought a rigorous method of critical analysis to the study of isnads and the texts and traditions they are supposed to authenticate. His methodology included "form criticism, redaction criticism, and literary criticism, just as they had been [applied] in the 
study of early Christianity and Judaism as pioneered by Rudolph Bultmann and Jacob Neusner" (Berg, 2000, p. 492). With his insights into classical Arabic language, Middle Eastern archeology, Judeo-Christian literature and traditions, and accounts of the Muslim conquests written by non-Muslims, Wansbrough proposed a drastic, yet "provisional" revision of Islamic history (Berg, 2000, pp. 494-495). Berg summarizes Wansbrough's key findings as follows:

During the early Arab expansion beyond Arabia, there is no evidence that the conquerors were Muslim. Almost 200 years later "early" Muslim literature began to be written by the Mesopotamian clerical elite. The implications may be that the hitherto secular polity discovered and adopted a new movement, which, though a non-Jewish, non-Christian movement, was the product of a Judeo-Christian sectarian milieu. This movement and its history were soon Arabicized. The Koran, however, took somewhat longer to be canonized-not until circa 800 C.E. (2000, p. 495).

A number of scholars have pursued the new paradigmatic approach to Islam initiated by Wansbrough, and several of his predecessors. Most of them generally accept the existence of a historical figure named Muhammad, but continue to debate the origins of the Quran and the development of Islam. The principle criticism regarding Islam itself is that it did not emerge from the desert as a fully defined and self-reflexive system of belief and way of life (al-Rawandi, 2000, p. 71). Linguistic, literary, and archeological evidence indicate that it took several centuries for Islam to develop:

The development of Islam as a potentially universal religion, capable of absorbing non-Arabs in large numbers, followed only after the emergence of Arabic as a literary language during the first half of the eight century. It happened only after the centre of Arab military and political power had shifted away from Arabia, first to Syria and then to Iraq. Few of the first men of Arabic letters were themselves Arabs by birth. Most were descended from the educated Greeks or Persians enslaved in the wars of conquest, who were recruited as bureaucrats by the Umayyad and Abbasid caliphs for their knowledge of earlier systems of law and administration. It is increasingly widely recognized by modern Islamicists that the way these men went to work was by codifying the law and custom of their own times and then authenticating their findings by attributing them to the oral 
tradition handed down from the Prophet and his contemporaries. The literary culture of Islam was thus a much more sophisticated and broad-based system than could ever have emerged from the seventh century Hijaz, and it was only after it reached this form that men of learning began to migrate to Egypt and Tunisia to establish schools of theology and law capable of attracting an educated Christian population into the Islamic fold (emphasis added) (Oliver, 1991, p. 85).

This new paradigm of Islamic studies, however, does not change the resulting impact of the Arab conquests of the so-called Middle East and northern Africa. Over time, these bands of horse and camel-mounted warriors adopted the new faith and added to their mission of conquest one of conversion. With conquest and conversion came immense power and wealth and the opportunity for Muslims to interact with and influence diverse cultures in Africa, Europe and Asia. Their strategic geographic location also afforded them the advantage of being in the center of the flow of goods and ideas from Europe and Africa in the West, to India and China in the East. Thus, Muslims found themselves and their empire at the very heart of the world, as they knew it. Yet religion and warfare were not sufficient to sustain and maintain Muslim hegemony. To keep the heart of this new faith-based political regime running, Muslims invested heavily in slavery and the slave trade. As David Brion Davis puts it: "The Arabs and their lightskinned converts from Morocco to Iran were the first modern people to create a continuing demand for large numbers of foreign slaves, a demand that persisted from the seventh century until well into the twentieth" (1984, p. 47). Most of this traffic in human beings was centered on Africa. And, as will be discussed below, Muslims grounded and founded their justification for the enslavement of "others" in the Mosaic and Noachic distinctions: the Mosaic distinction and its true/false dichotomy divided the world into Muslims and infidels, and the Noachic distinction established a scriptural basis for viewing "black" people, in particular, as divinely selected and sanctioned for servitude. 


\section{MUSLIM SLAVERY}

After the establishment of Islam, Muslims, like their Christian and Jewish

predecessors, continued the existing systems of slavery that had been prevalent in the ancient world for centuries. In the traditions of the Old and New Testaments, the Quran recognized the legitimacy of the institution of slavery and offered practical guidance regarding the treatment of slaves. Ronald Segal in Islam's Black Slaves notes:

The Koran, while upholding the distinction between owner and slave as part of the divine design, also expressly encouraged the freeing of slaves as an act of piety, whose merit might explicate particular crimes. And Muslim slaves were especially recommended for emancipation, in a celebrated saying attributed to the Prophet: "The man who frees a Muslim slave, God will free from hell, limb from limb" (2001, p. 35).

Muslims did not always follow the Quranic edicts regarding the benevolent treatment of slaves or their manumission. Instead, as Islam grew through trade and conquest, and as the slave trade became an integral part of Islamic societies and their economies, its conduct was carried out with a brutal inefficiency and inhumanity. The brutality of Muslim slavery was especially true in sub-Saharan Africa, where slaves were "punished at will," treated as "sacrificial victims," and rarely freed from bondage (Oliver, 1991, p. 119). Davis sees the growth of the long distance trade in African slaves as initially dependent on "the westward spread of the camel and the North Arabian saddle" (1984, p. 35). Camel-breeding nomadism spread throughout the region, creating caravan traffic and commercial networks that stimulated the growth and development of trading 
cities along their routes. Davis states: "Despite the paucity of direct evidence, it is probable that well before Islam these desert caravans included black slaves who traveled mainly on foot but who were dependent on food and water carried by camel-riding merchants" (1984, p. 35).

The inclusion of slaves who were "black" in the pre-Islamic slave trade does not mean that only "blacks" were enslaved or that the enslavers were necessarily "white" Arabs. Given the African origins of certain Arab populations, and the Ethiopian conquest of South Arabia in the century before Muhammad's birth, it can be argued that the presence of "black" slaves in pre-Islamic Arabic societies also reflects a "black" component in the indigenous population of the Arabian Peninsula. Modern systems of racial classification and ideology, including the so-called "Hamitic Hypothesis" (see Edith Sanders 1969), permeate and distort the research and scholarship on such questions and issues. The use of scare quotes around the word "black" throughout my thesis reflects my concerns about the term's ideological origins and the tendency to interpret it according to the racialist and racist connotations it has accrued since the Islamic and Atlantic slave trades. With that being said, it is also clear that color distinctions and color prejudice did exist in pre-Islamic Arab culture. Tradition records Muhammad as making this comment in his last sermon: "No Arab has any priority over a non-Arab and no white over a black except in righteousness" (cited in Segal, 2001, p. 46). Ethnocentrism and color prejudice must have been common social phenomena to warrant the attribution of this statement to Islam's prophet. To what degree such attitudes existed in early Islamic Arabia is a matter of debate. What can be stated with a greater degree of certainty is that the conquest of the Near East and North Africa fostered the idea of Arab superiority. 
Moreover, the ensuing large-scale importation of millions of African slaves into Muslim lands from previously unknown regions of Africa probably exacerbated and increased Arab ethnic hostility and contempt.

The Arab conquest of Egypt in 639 provided the staging ground for the North African jihad and the eventual conversion of millions of Christians and cosmotheists to Islam. Although African resistance to Arab incursions was fierce and protracted, this chapter of North African history often has been overlooked. The region's Berbers, Christians, and Jews, however, mounted major campaigns against the invaders. When faced with defeat, some chose martyrdom rather than submit. Others converted to Islam at the point of a Muslim sword. Afrocentric scholar J. C. deGraft Johnson in African Glory describes this neglected episode in African history as follows:

The Arab conquest of North Africa was no walk-over except perhaps in Egypt, where the Arabs were received as deliverers from the cruel rule of Byzantium. The resistance put up by Kuseila of Mauritania and by his relative Kahina reflected the African mood of the period. In fact, so determined were the African counterattacks that an Arab governor once remarked that the conquest of Africa was impossible; and that scarcely had a Berber tribe been exterminated when another came to take its place. However, after Kahina's defeat and death in 705, African resistance eventually weakened (1954, p. 68).

The dramatic expansion of the Arab slave trade into Africa followed in the wake of North African defeats. Oliver notes:

The trans-Saharan slave trade was, in fact, the key to the politics of medieval North Africa. Slaves were required first and foremost as soldiers. Locally recruited slave soldiers enabled small groups of immigrants, like the Ibadis, to create small states, some of which later grew larger (1991, p. 86).

The impact of the Arabs and Islam on continental African cultures often has been treated and regarded as a "civilizing" mechanism rather than the source and cause of a human catastrophe. The connection between jihad and the growth and perpetuation of the 
Islamic slave trade in Africa is indisputable. Nevertheless, Islam's role in the expansion of "black" slavery throughout the world has not been accorded the prominence it deserves in the West and particularly among Pan African scholars. The Great Sahara, a popular study of the vast North African desert and its exploration, offers this blunt comment on the Arab role in the globalization of African slavery:

This was the slave trade which, under the efficient direction of the Arabs, was soon to involve the whole civilized world from the end of the Middle Ages to the beginning of the twentieth century. The ancient world, of course, was based on slavery, but not on African slaves. The exploitation of black labour was the contribution of the Arabs to mankind, for it was they who organized the traffic in human merchandise out of Africa to the Atlantic and Mediterranean ports. In short, the slave trade became the cornerstone of Saharan economy for the next thousand years (Wellard, 1964, p. 113).

The total numbers of African slaves traded by Islamic states over the thirteen and a half centuries of the Muslim slave trade remains a topic of much debate. Segal cites various estimates ranging from 7,220,000 (Paul Lovejoy) to 14,000,000 (Raymond Mauvy) (2001, p. 56). The vast expanse of space and time and the lack of data for the early centuries of Islamic trade make these figures hardly reliable. Nevertheless, they suggest that the Islamic trade was comparable in numbers to the Atlantic trade overall and, when broken down and viewed by centuries, they indicate a marked increase in activity after the Atlantic trade was abolished. Segal, citing Lovejoy's data, notes:

The nineteenth century exceeded any of the previous twelve centuries in the volume of this trade, and the related documentary evidence is more extensive and exact than it is for any previous century. Some 1,200,000 have been estimated for the trans-Saharan routes, 450,000 for the Red Sea route, and 442,000 for East African coastal exports: an annual average of 20,000, or more than 2,000,000 in all (2001, p. 56).

Contrary to the old cliché, these numbers do not speak for themselves. Export data alone cannot convey a complete or accurate picture of the slave trade's demographic 
consequences for African societies or its economic and social benefits for Islamic states. The slave trade involved several brutal activities: raiding, capturing, transporting, storing and selling slaves. Each stage resulted in the significant loss of African lives in addition to those lost during their exportation by force. The quantitative analyses of the Atlantic slave trade performed by H.S. Klein (1999), M. Klein (1992) Manning (1992), Miller (1988) and Curtin (1969) include estimates of mortality rates for each step of the trade listed above. The numbers in those studies vary, and their authors do not fully agree in their evaluations of the data, yet a general consensus exists that the trade—-through its inhumane and brutal practices—-killed millions. When viewed as an aggregate, the related losses in the Atlantic trade appear greatly disproportionate to the numbers of captives who actually reached the final steps of purchase and forced labor. Similar data or analysis of data for the Islamic trade has been lacking, and much of what has been available for study is anecdotal rather than systematic or dispositive. Segal cites such an example:

One late nineteenth-century writer held that the sale of a single captive for slavery might represent a loss of ten from the population-from defenders killed in attacks on villages, the deaths of women and children from related famine, and the loss of children, the old, and the sick unable to keep up with their captors or killed along the way in hostile encounters or dying of sheer misery (2001, p. 62).

The arduous and brutal nature of the Sahara traffic in the Islamic trade offers a situation for study and analysis comparable to the Middle Passage of the Atlantic slave trade. Such desert crossings often covered distances of a thousand miles or more as the slave coffles made their way to Mediterranean trading centers in Tunis, Tripoli, Benghazi and Cairo from Lake Chad, Timbuktu, and Kano. Medieval Muslim scholars Ibn Khaldun, Ibn Battuta, and Leo Africanus (who later converted to Christianity), and modern European explorers and adventurers Frederick Hornemann, G. F. Lyon, Henry 
Barth, and Rene Callie recounted personal observations of the trans-Saharan trade. Such anecdotal reports have been important sources of information given the lack of detailed studies of this commercial traffic. Few contemporary scholars, however, have performed statistical and demographic studies of the Arab slave trade. Patterson cites a study by Ralph A. Austen that estimates a total of 6,850,000 slaves were transported in the Sahara trade from $650 \mathrm{CE}$ to the nineteenth century, and suggests that perhaps as many as five million Africans were transported in the Arab East African trade over the same period (Patterson, 1982, p. 159). These numbers support the growing consensus that the Islamic trade was comparable to the Atlantic trade in the export of enslaved Africans.

In a rather diffuse essay on the formal demography of the slave trade, Manning calculates an average mortality rate of twenty percent or more for the global slave trade (Occidental and Oriental), and projects an estimated loss of "some 5 million people over three centuries" (1992, pp. 120-121). The Islamic or Oriental trade, however, operated for over thirteen centuries and continues today in the Sudan, Mauritania and Saudi Arabia. While it is perhaps impossible to enumerate with any degree of certainty the annual and aggregate mortality rates associated with the North and East African Islamic trade, when combined with the estimated numbers of slaves who survived and were incorporated into the Muslim slaveocracy system (12 million according to Austen's data cited by Patterson above) a general picture of the demographic disaster perpetrated on the African continent begins to emerge. For example, Manning points out: "In 1600 Africans at home and abroad were clearly a minority of the world's slaves; in 1800 they were the overwhelming majority of all slaves" (1992, p. 121). Manning also describes the demographic results of this trafficking as follows: 
From 1700 to 1850, the population of sub-Saharan Africa as a whole stagnated or declined in size because of the mortality of captives, the drain of slaves, and continued high mortality resulting from social insecurity. This was precisely the period in which the populations of Europe, the Americas and Asia began to grow rapidly. So while the African proportion of Atlantic basin population was perhaps $30 \%$ in 1650 , it had declined to roughly $10 \%$ in 1850: adding in the Africandescended populations of the Occident and Orient would bring the African population up to $15 \%$ in 1850 (1992, pp. 121-122).

The lack of data for the early years of the Islamic trade in Africa problematizes any effort to quantify the human and social costs of this enterprise. Despite such difficulties, however, a study on the order of Walter Rodney's How Europe Underdeveloped Africa (1974) or Chinweizu's The West and the Rest of Us (1975) is sorely needed to address how Muslim Arabs and their converts systematically looted, exploited and undermined traditional African societies in their efforts to foster and sustain Islamic hegemony. Such a study also would give particular attention to those aspects of Islamic slavery that distinguish it from Occidental and New World slaveocracies. Segal's Islam's Black Slaves offers an important step in that direction. But Segal's study is more noteworthy for its broad and general overview of the subject rather than providing a deeper analysis of Islam's intolerance of traditional African belief systems, its systematic exploitation and destruction of African societies, and its decisive role in the development of antiblack racism. Segal, however, does make important distinctions between Islamic and Occidental slavery:

Slavery in Islam was very different. A system of plantation labor, much like that which would emerge in the Americas, developed early on, but with such dire consequences that subsequent engagements were relatively rare and reduced. Moreover, the need for agricultural labor, in an Islam with large peasant populations, was nowhere near as acute as in the Americas, where in some West European colonies, conquest had led to the virtual extermination of the indigenous peoples from disease and forced labor. Slaves in Islam were directed mainly at the service sector-concubines and cooks, porters and soldiers-with slavery itself primarily a form of consumption rather than a factor of production. The most 
telling evidence of this is found in the gender ratio. The Atlantic Trade shipped overall roughly two males for every female. Among black slaves traded in Islam across the centuries, there were roughly two females to every male (2001, p. 4).

The "dire consequences" for early experiments with plantation slavery alluded to by Segal above refers to the use of East African slaves known as Zanj in massive land reclamation projects in Southern Iraq in the ninth century. The Zanj, taking advantage of political turmoil in Iraq, led a revolt that lasted for fifteen years (868-883 CE) and that threatened the Abbasid Caliphate in Baghdad. In the end, the Zanj were brutally put down and the practice of concentrating large numbers of slaves was discouraged (Irwin 1977, 77-78). African slaves also were used in palmeries or date plantations in northeast Arabia and the Sahara, for agricultural work in fifteenth century Morocco, for cotton production in nineteenth century Egypt, on clove plantations in nineteenth century Zanzibar, and for growing grain in Mombassa and Malindi on the East African coast (Segal, 2001, pp. 44, 60). The vast majority of Islam's African slaves, however, were forced to labor as porters, soldiers and domestic workers. The most sought after and prized domestic workers were female concubines and male eunuchs.

The value Muslims placed on female slaves resulted in a significant difference in gender ratios between the Atlantic and Islamic slave trades, as noted by Segal above. Many of the African women victimized by this human trafficking wound up as concubines in Muslim households. Some of them became Muslim wives. Segal offers this quote from the twelfth century geographer al-Idrisi (1110-65), which vividly describes the physical attributes and appeal of Nubian women in particular:

Their women are of surpassing beauty. They are circumcised and fragrantsmelling ... their lips are thin, their mouths small and their hair flowing. Of all black women, they are the best for the pleasure of the bed ... It is on account of these qualities of theirs that the rulers of Egypt were so desirous of them and 
outbid others to purchase them, afterwards fathering children from them (2001, p. $50)$.

Concubinage was not always a socially degraded position, as Muslim masters often married their female slaves without scandal or disrepute. Many such women, however, wound up in the enormous harems of the ruling elite. Segal cites two extreme examples: the harem of 'Abd al-Rahman III (2001, 912-61) in Muslim Spain which contained "some six thousand concubines" and that of the Fatimid palace in Cairo with "twice as many" (2001, p. 39). "Black" and "white" female slaves also were employed as singers, dancers and musicians. Several famous schools in Medina, Baghdad, and Cordoba provided specialized training in musical and literary arts for female artists. The vast majority of female slaves, however, performed domestic duties as cooks, nursemaids, and household servants. Not all "black" women in Muslim societies were slaves, and some fortunate few were celebrated for their artistic talents or intellectual achievements. Israq as-Suwaida, a "black" woman who lived in tenth century Moorish Spain, achieved great recognition for her grammar and prosody (Segal, 2001).

The wealthy elite generally divided the living spaces in their homes into separate quarters for men and women. Male domestics, who also worked in these households as servants, grooms, messengers, porters and guards, generally were kept away from the women's apartments. Given the Muslim preoccupation with codes of honor and chivalry, much effort was expended protecting and secluding women. To this end eunuchs became a prominent feature in Muslim households. These castrated slaves were believed to pose no sexual threat (or temptation) to household women, although books like Sheikh Nefzawi's Perfumed Garden and the more widely known One Thousand and One Nights 
relate stories suggesting that all eunuchs were not equally "unmanned" or devoid of the desire or the ability to satisfy a woman.

The creation and use of tens of thousands of eunuchs remains one of the most horrific and detestable features of Islamic slavery. Segal points out: "In ancient Arabia, castration seems to have had no place; and when it subsequently did acquire one, the practice was roundly condemned by early Muslims” (2001, p. 40). Muslim law forbid mutilation of any type, but the law was circumvented through the purchase of slaves castrated outside the borders of Islamic states:

In the Middle Ages, Prague and Verdun became castration centers for the supply of European eunuchs; Kharazon, near the Caspian Sea, a center for the supply of Central Asian ones. Further circumventions, on Islamic territory, were pursued on the basis that the operations were conducted by non-Muslims. In tenth century Islamic Spain, Jewish merchants reportedly performed the operation. In the nineteenth century, Christian monks ran a castration center at their monastery of Deir al-Jandala near Abu Tig, a small town in Upper Egypt (2001, p. 40).

From the above statement it seems that commercial castration of males for Muslim markets enjoyed the dubious distinction of being perhaps the only genuinely ecumenical enterprise practiced in the so-called Middle Ages. Muslims also must be included in the foregoing list. Despite the purported Islamic aversion to mutilation, Muslim slave traders in Africa regularly performed castrations while en route to North African slave markets. Wellard describes the hazards of the procedure and the journey:

Since the survival rate was one in ten for the castration operation and one in ten for the trans-Saharan journey, the odds against a young castrato reaching the Tripoli market were, theoretically, only one in a hundred. But the slave merchants could not afford to risk such odds even in the transportation of human beings who were easier to capture and transport than civet-cats. So the castrati probably received the preferential treatment accorded the especially beautiful virgins who were carried in cages on the backs of camels. The other slaves, of course, walked and were driven from well to well, arriving at the coast in the form of living skeletons, there to be fattened up before being sold at the auctions (author's emphasis) (1964, p. 122). 
Davis points to the racially discriminative manner in which the operation was performed on "black" youth: "The frequent castration of black males for Muslim masters has been described as 'a complete and barbarous amputation, level with the abdomen.' On whites the operation was performed with more generosity" (1984, p. 44). White victims of this practice were left with their testicles intact. Segal, citing the same sources, adds the further note that African males were forced to endure the extreme procedure "based on the assumption that the blacks had an ungovernable sexual appetite" (2001, p. 52). This obsession with black penises and libido appears often in Arabic literature. In Moorish Spain it also appears to have contributed to medieval Spanish concepts of the "black stud" (Piedra, 1993, pp. 820-846). A pathological fear of the black penis also can be observed in the peculiar American practice of castrating black males during lynching, especially those accused of raping or "reckless eyeballing" white females. Orlando Patterson's comments on the ritualistic psychological and social nature of American lynching in Rituals of Blood seem applicable and apposite to the earlier Muslim attitudes herein discussed:

The castration of many of the Afro-American victims was indeed a kind of communal rape ... It may well have been indicative of sexual jealously and castration anxieties on the part of the Euro-American oppressors and their need to deny any hint of manhood and independence to Afro-American males (1998, p. 174).

The idea of castration as a sexual act may seem farfetched, but in Islamic societies it often served as a prelude to rape in that it created male concubines for Muslim harems. Thus eunuchs were prized not only as domestic servants and guards who were theoretically unable to have sex with household females, but also as the sexual objects and partners of Muslim males. Segal cites a tradition of homosexual love poetry in Persia 
that underscores the commonplace nature of same-sex intercourse in some Islamic societies. The Muslim participants in these liaisons, however, were not necessarily exclusively homosexual; such relations often occurred between married men and their passive male lovers or concubines. In the specific case of eunuchs, the young male, "regardless of his sexual inclinations," was forced to accept the receptive "female" role, and the attendant dishonor that accompanied such a situation in the aggressively masculine Muslim culture (Segal, 2001, p. 42). Thousands of African boys found themselves suddenly captive in this system of mutilation, rape and degradation. Yet, ironically, accounts from inside and outside the Muslim world abound with countless references to the respect bestowed upon "black" eunuchs and the many examples of their prominence and power in Muslim societies in North Africa and the Near East. The reported great esteem accorded to them perhaps was in recognition of their physical and mental capacity for survival. According to A. B. Wylde, a British official who served as consul in Jedda in the late nineteenth century, every eunuch who survived represented "at the very least, 200 Soudanese done to death ... say there are 500 eunuchs in Cairo: 100,000 Soudanese had died to produce these eunuchs" (cited in Segal, 2001, p. 156). The massive mortality rate and the insatiable demand for these domestic slaves kept their market prices high throughout the thirteen centuries of the Islamic slave trade. On average, in the sixteenth century, a eunuch would sell for twice as much as a female concubine or male slave. The castration of male slaves continued openly in Arabia into the early twentieth century (Segal, 2001, p. 156). After 1910, international attention forced Muslim slave traffickers to conduct their operations in secret. Given the intractable nature of this odious institution in Islamic society, it is not unreasonable to 
assume that eunuchs continue to exist and serve in elite Muslim households in the Sudan, Saudi Arabia, Morocco, Mauritania and elsewhere in the Islamic world.

The Islamic slave trade transported millions of Africans to the Near East, India and China. Arabs and their Muslim allies in Africa also served as middlemen in the Atlantic slave trade. And Arabs and their Afro-Arab partners enslaved millions of Africans in Africa. Muslims certainly did not introduce slavery to Africa, but they created new sources of slaves through jihads and transformed local slavery regimes into global supply chains that ultimately depopulated and devastated vast areas of the continent. Despite the frequency with which "blacks" in Africa converted to Islam for religious sustenance and protection from the depredations of jihads and slave raids, "black" Muslim converts remained the victims of Islamic slave traffickers. Many Arabs, regardless of their own "African" ancestry, saw "black" Africans, regardless of their religious affiliation, as commodities to be bought and sold. A nineteenth century Moroccan historian, Ahmad ibn Kalid al-Nasiri (1834-97), incensed by the regular importation of thousands of enslaved 'black' Muslims, and proclaiming them to be "among the best peoples in regard to Islam, the most religiously upright, the most avid of learning and the most devoted to men of learning," wrote this searing protestation of their treatment:

Thus it will be apparent to you the heinousness of the affliction which has beset the lands of the Maghreb since ancient times in regards to the indiscriminate enslaving of the people of the Sudan and the importation of droves of them to be sold in the market places in town and country where men trade in them as one would trade in beasts-nay worse than that. People have become so inured that, generation after generation, that many common folk believe that the reason for being enslaved according to the Holy Law is merely that a man should be black in colour and come from those regions. This, by God's life, is one of the foulest and gravest evils perpetrated on God's religion, for the people of the Sudan are 
Muslims having the same rights and responsibilities as ourselves (cited in Segal, 2001, p. 65).

Al-Nasiri's statement underscores the paradoxical nature of Islam's relationship to "black" Africans. Although they were among the first converts to the faith, led Muslim armies to victories across the globe, and through intermarriage and intermixture became the mothers, fathers, wives, husbands, children of Muslims throughout the Islamic world, they often remained marked by an indelible "otherness" in the Arab imagination. Given the Muslim belief that the Quran constitutes the indisputable word of Allah, its sanction of slavery authorizes and justifies the maintenance of the institution in perpetuity. As noted above, as slavery declined in the west in the nineteenth century, the Muslim slave trade showed a dramatic increase. Slavery continued openly in Muslim lands into the twentieth century, where it operated with the acquiescence of the European imperialist powers that had conquered and colonized those territories. It continues today, mainly as concubinage and other forms of domestic slavery. Segal devotes a chapter of his book to the "survivals of slavery" (2001, pp. 199-223) in twenty-first century Islamic states. Ironically, millions of African slaves exported to Muslim countries were absorbed through intermarriage and intermixture with their Arab, Persian and Turkish masters and mistresses. Their assimilation through conversion to Islam, their frequent manumission, the different gender ratios, the documented low birth rate of black females slaves in the Arab world, the massive numbers of black male slaves who were unable to procreate due to castration, and the high mortality rate for slaves overall in Muslim lands, accounts for the fact that very little visible evidence exists today of the legacy of an Islamic trade that was equal to or greater than the Atlantic trade. Conversely, in the Americas, with its 
highly institutionalized systems of apartheid and racial oppression, "black" people remain a highly visible and unassimilated presence.

Finally, it is the human factor on both sides of the equation —-the enslaved African and the Muslim enslaver—-that adds an incalculable element to the business of human trafficking and its social consequences and legacy. The only constant in all of this is the persistence of slavery in Islamic societies and the lack of scholarly and political attention it has received in the west and from the Pan African world. A systematic treatment of this failure in scholarship and intervention is beyond the scope of this thesis. Instead, we will now turn our attention to Islam's role in the formation of proto-racist and racist theories regarding "black" people and the transmission of those ideas to the west. 


\section{ISLAM AND THE DEVELOPMENT OF ANTIBLACK RACISM}

Islamic religious ideology grounded in the Mosaic distinction (the true/false dichotomy of monotheism) and influenced by the Noachic distinction (the curse of Ham) provided a crucial context and content for the social construction of Arab identity and the Arab view of "others." Arabs also assimilated and reworked the Hellenistic, Semitic and Iranian ethnological conventions from the Mediterranean world they conquered. With this sociohistorical background in mind, I selected the following four points with which to examine further the social construction of "black" identity and "blackness" in Islamic thought: (1) the grounding of Islam in an uncompromising monotheism that expresses the true/false and believer/infidel dichotomies in their most extreme forms-jihad; (2) the creation of a vast Arab empire through the Islamic conquest of large sections of the Near East, Africa, Europe and Asia; (3) the Islamic slave trade in Africa; and (4) the "mulatto problem," a term taken from the work of Chancellor Williams (1974) and used here to describe the antiblack attitudes of Afro-Arabs to their "African" heritage, and the manifestation of such attitudes in the social construction of "black" identity and the social treatment of "black" people.

Issue (1) — the Islamic adoption and reformulation of the Mosaic distinction-was introduced and examined above. The additional discussion offered here specifically focuses on how the ideology of monotheism influenced the development of certain stereotypic notions of ethnicity that later informed concepts of race and practices of 
racism. Islam's purported founding in Arabia by Arabs fundamentally changed the Arabs view of themselves and "others" in part by enabling them to confront the powerful institutions of Judaism, Christianity and Zoroastrianism with their own monotheistic ideology. The same religious ideology that fostered a common Arab social identity rooted in the local Arab ethos also reified that identity and made it a potent and authoritative force in expanding Arab socio-economic power. For Muslims, the consummate Muslim is the Prophet Muhammad. His life exemplifies Muslim comportment, piety and social responsibility. As the Prophet of god and revealer of the Quran, Muhammad links the Arabs to Allah in the same way Moses links the Jews to Yahweh. It is this image of Islam's prophet, and the Islamic culture that instantiates it, that solidified the decentralized fragments of the great empires conquered by Arabs and the new Islamic states that emerged in regions as remote and different from each other as Senegal, Bosnia, India and Indonesia. Despite the globalization of Islam, and the fact that Arabs now constitute a small minority of its adherents, the faith remains Arab-centric in several key respects: in the sacred language of the Quran; in the location in Saudi Arabia of the primary Islamic religious sites (Mecca and Medina); and in adoption of Arab manners and customs by some non-Arab Muslims. By these means Islam retains at its core key components of "Arab" character and ethos.

In contravention of Muhammad's admonitions to treat all believers as equal members of a religious fraternity, the Arabic origin and character of Islam facilitated the development of discriminatory policies and practices by Arabs against non-Arab Muslim converts. Irwin succinctly states: "Non-Arab Muslims were regarded as inferior and subjected to whole series of fiscal, social, political, military, and other disabilities" (1977, 
p. 123). According to Irwin, the term mawla (pl. mawali), which means "freedman" or "client" in Arabic, applied to non-Arab Muslim converts and appeared in a variety of sayings denoting the second-class status that accompanied this distinction. Mawali were addressed by their personal names without the honorific kunya (the name an Arab derives from his or her oldest son); they were not allowed to precede Arabs in processions; walk alongside them; sit at table with them during meals unless seated at the end to denote their status; or pray at a funeral if an Arab was present. Even a "half-breed" with a free Arab father and an enslaved mother of another ethnicity ranked higher than non-Arab Muslims (Irwin, 1977, p. 123). Irwin asserts that the result of such attitudes and customs meant: "The struggle for equal rights of the non-Arabs was one of the main themes of the first two centuries of Islam" (1977, p. 124). In time the intermarriage of Arabs and nonArabs mitigated or submerged ethnic distinctions and class barriers. More importantly, many of the conquered non-Arabs converted to Islam, adopted Arabic as their language, and became Arabs in their customs and manners. This assumption of Arab identity was especially common in parts of Africa.

If discriminatory practices based on ethnic origins and the fact of recent conversion existed within Muslim ranks, it should be obvious that non-Muslims would comprise an even lower status in Islamic societies. Non-Muslim monotheists (Jews and Christians) ranked below non-Arab Muslims, but pagans or cosmotheists generally comprised the absolute bottom tier in the Arab social hierarchy (the exceptions being the ancient and powerful civilizations of India and China). Muhammad saw his mission as one of restoring hanifiyyah, the "pure" faith of the Abrahamic tradition, and himself as the last chosen prophet of god. Muslims therefore share with Jews and Christians a 
common identification with the Abrahamic lineage and the Mosaic distinction that emerges from it and a common heritage of "sacred" literature as "people of the book." Consequently, Muslims of the imperial era of Islamic expansion tolerated the continued presence of Jews and Christians in conquered Muslim lands as long as they refrained from proselytizing and paid the onerous taxes that were levied on non-Muslims. The exception to this general policy was the city of Mecca from which non-Muslims were banned. Lewis describes Muslim policies toward non-believers as follows:

For atheists or polytheists the choice was clear-Islam or death. For Jews and Christians, possessors of what were regarded as revealed religions based on authentic though superceded revelations, the choice included a third term-Islam, death, or submission. Submission involved the payment of tribute and the acceptance of Muslim supremacy. Death might be commuted to slavery. Those who submitted, according to Muslim law and practice, could be accorded the tolerance of the Muslim state. The resulting relationship was regulated by a pact called, in Arabic, the dhimma (1982, p. 63).

The Arab opinion and treatment of African peoples depended on the religious and social variables discussed above. The centuries-old traditions of Judaism and Christianity in Ethiopia, and the region's ancient and enduring reputation for civilization and learning set them apart in the Arab mind from other, less-developed cultures they encountered in Africa. And, as Irwin explains: "During the lifetime of the Prophet the good reputation of the Ethiopians was further increased by the kindly welcome afforded to Muslim refugees from Mecca" (1977, p. 126). The following comment from the eminent Pan Africanist Jan Carew, underscores the centrality of this region of Africa in the development of Islam:

When the Prophet Muhammad fled to Medina, some of his most devoted followers crossed the Red Sea and began to proselyte in Ethiopia. So, the first significant groups of the converted were Africans. The Muslim religion, therefore, was filtered through the great African civilizations of the Nile Valley-the Ethiopian, the Nubian, and the Egyptian—in its earliest stages (1992, p. 252). 
Again, with the notable exceptions of India and China, Muslims had no tolerance for pagan cultures. Triumphant jihads in North Africa resulted in the massive enslavement of pagan Africans under the auspices and sanction of Quranic tradition. The rigorous application of this religious mandate to eliminate pagan cultures changed the course of African history, and decisively predisposed European perceptions of the continent's inhabitants long before they pursued their own imperialist ambitions in Africa. The Noachic curse also appeared frequently in medieval Arabic literature to justify and rationalize the Islamic trade in "black" slaves. The centuries preceding the revelation and formulation of Islam witnessed a major elaboration of Noah's curse in rabbinic treatises. From the fourth to the sixth centuries several aforementioned rabbinic commentaries "darkened the face of Ham and made the curse of Noah read: 'Your seed will be ugly and dark-skinned"” (Evans, 1980, p. 26). Two factors perhaps explain this development. First, the racial stereotyping of slaves by Jews may have reflected an increase in the trade in "black" slaves in the region. Second, as Evans puts it: "During the Middle Ages the Jews became to a larger extent a European as well as a Near Eastern people, and they came to share the stereotypes of both regions" (1980, p. 27). Evans goes on to note: "After the sixth century, it was those less Europeanized sons of Shem, the Arabs, who further developed the tradition of Ham" (1980, p. 27). Werner Sollors in his incomparable study of interracial literature, Neither black nor white yet both, offers the following version of Noah's curse, recounted by Muhammad al-Tabari (circa 838-923), a renowned Persian historian:

Noah begat three, each one of whom begat three: Shem, Ham, and Japheth. Shem begat the Arabs, Persians and Byzantines, in all of whom there is good. Japheth begat the Turks, Slavs, Gog, and Magog, in none of whom there is good. Ham 
begat the Copts, Sudanese and Berbers [...] Ham begat all those who are black and curly-haired, while Japheth begat all those who are full-faced with small eyes, and Shem begat every one who is handsome of face with beautiful hair. Noah prayed that the hair of Ham's descendants would not grow beyond their ears, and that wherever his descendants met the children of Shem, the latter would enslave them ... (1997, p. 90).

Evans refers to this same quoted passage as "typical of the form it [Noah's curse] had assumed by the later Middle Ages" (1980, p. 33). The influential Tabari's rendition of the curse reflects its common and frequent appearance in medieval Muslim literature despite the fact the Quran makes no mention of it in its sparse treatment of the story of Noah (see Suras 49:13, 30:22). Ironically, al-Tabari, in the above quote, directs his harshest remarks to Japheth's descendants. What is more noteworthy, however, is the decidedly "racial" tone of his exegetical treatment of the myth. As Sollors points out: "This [passage] is an example of a genealogy that is moving into the direction of identifying peoples by 'racial' features ...” (1997, p. 90).

The Quran, a seventh century composition, does not equate slavery with blackness in its rendition of the Noah story or elsewhere in its texts. Yet, as noted by Davis, increasingly after the eight century: "Arabic literature was already merging blackness of skin with a variety of derogatory physical and characterological traits" (1984, p. 42). The eighth century marks the true beginnings of Arabic literature. Prior to Arab imperialism, poetry was the most common form of Arabic writing. Thus the very beginning of the Arabic prose tradition saw the establishment of a tropology that not only commonly linked blackness to servitude, but also to sin, evil, licentiousness, and bestial behavior. By the late medieval era the designation Banu Ham (the "sons of Ham"), with its decidedly pejorative connotations, had become a synonym in popular Arabic literature for Sudan, "black" people (Evans, 1980, p. 29). 
The biblical genealogy delineated in the Noah story (and shared by Jews and Christians) underwent important revisions in medieval Muslim hands. Evans points out that Egyptians and Berbers-who were clearly identified in the Genesis "tables of nations" as descendants of the accursed Ham — were exempted from the curse because: "they were the products of cultures more urbane and sophisticated than that of their conquerors" (Evans, 1980, p. 33). This important cultural distinction between Arab conquerors and certain societies they defeated in Africa and the Near East will be dealt with below in issue 2. Here it worthwhile to note that Arabs sought to reprieve the citizens of those of ancient centers of culture and learning from Noah's curse through revising the genealogy or by simply absolving them of the "sin committed by their ancestor" (Evans, 1980, p. 33). So-called sub-Saharan Africans did not receive this generous exemption. Instead, Arab writers generally depicted and characterized them as the lowest of human beings or sub-human in nature, mentality and temperament.

The examples cited above illustrate how the Mosaic distinction influenced and amplified the ethnocentrism, religious bias and color prejudice that informed the Islamic Arab worldview. The true/false dichotomy in monotheism and its manifestation in the social construction of believers/infidels achieved its most violent expression in the form of jihad or holy war. Those unfortunate pagan cultures that found themselves in the path of this unprovoked onslaught often had to choose between the decidedly limited options of enslavement or extermination. The Noachic distinction or curse of Ham provided Arabs with a convenient religious justification for the perpetual exploitation of certain "black" people within and outside the Muslim sphere of influence. Such beliefs and attitudes and the policies that institutionalized them in Muslim societies, in time, came to 
encompass nearly all "blacks" regardless of their ethnic origins or religious beliefs. The explanation for this can be seen, in part, in the transformation of the slave trade. Evans contends: "the reason Muslim slavery became Negro slavery was because the rise of Islam eliminated from the Mediterranean slave trade an important source of light-skinned slaves" (1980, p. 28). With freeborn Muslims exempted from slavery, and dhimmis (Jews and Christians in Muslim states) afforded the protection of Islamic law: "Lawful captives had to be taken either north of the Mediterranean or south of the Sahara" (Evans, 1980, p. 28). Although many European slaves entered the slave markets in the early centuries of Islam, after the tenth century most slaves in Muslims lands were "black" by popular demand and due to simple supply-side economics. The color-coding of slavery—an outgrowth of the merger of the believer/infidel dichotomy and the Noachian cursefostered and facilitated the color-coding of prejudice and the formation of antiblack racism. Nevertheless, intermarriage, intermixture and conversion often meant that "color" posed no permanent or impenetrable barrier to advancement in the Islamic world. Countless examples from all periods in Islam's growth and development support this fact—although it must be emphasized that over time the overwhelming majority of "blacks" in lands dominated by Arabs, Persians and Turks eventually came to occupy the lowest strata of those societies.

Issue 2-the role of Arab imperialism in the development of antiblack racism—of necessity, has been addressed in the sections above. In light of the rapid Arab successes in conquering vast portions of the globe, the fact often gets lost that many early Muslim armies were composed of fractious desert tribes who were united only by Islam and a common desire to plunder their neighbors. Given the initial perceptions of Islam as a 
tribal Arab religion and its early non-canonical ban on the conversion of non-Arabs, the original impetus for jihad was warfare to expand Arab hegemony rather than Islamic theology. The desert nomads who comprised the bulk of the Arab military forces were not enlightened bringers of science, technology or literate culture; they were, instead, raiders, plunderers, pillagers and killers (Bostom, 2005; Fregosi, 1998). Therefore, it was through military occupation and military rule over ancient centers of learning in North Africa and the Near East that Arabs acquired and assimilated the accoutrements, customs and skills of civilizations materially and intellectually more developed and sophisticated than their own. Within a few generations of establishing a far-flung global empire an international network of Arabic scholars and institutions of Islamic learning developed and flourished. Thus the great Islamic centers of research and education were located not in Medina or Mecca in Arabia, but in Cairo in Egypt, Baghdad in Iraq, Timbuktu in Mail, and Cordoba, Grenada and Seville in Moorish Spain (Pimienta-Bey, 1992).

The nearly instantaneous triumph of Arab armies over a vast portion of the Hellenistic and Roman empires—-filtered through Arab ethnocentrism and chauvinismno doubt strengthen their belief that they were the legitimate possessors and heirs of classical civilization. That they built a unique Muslim civilization on the foundation of ruined empires is indisputable. Arabic scholars translated and preserved great works of antiquity and used them to expand the frontiers of human knowledge. Jan Carew's description of Arab and Moorish contributions to the medieval world best summarizes this point:

Muslim scholars had found a particular fascination in the philosophy and science of the early Greeks (not realizing their debts to the Egyptians) and after translating the texts of Aristotle, Plato, Ptolemy, Euclid, Heracleitus, Galen, Hippocrates and others, they analyzed and improved upon them, drawing from 
their wide-ranging intellectual experiences and observations in the vast territories they ruled, and the polyglot races and peoples with whom they traded in knowledge, ideas and goods. Muslims scholars absorbed, synthesized and expanded upon the knowledge of the Ethiopians and Egyptians, the Phoenicians, the Greeks, the Chinese, and the Indians. A new and momentous forward leap in the theoretical and applied sciences evidenced itself in Moorish mathematics, medicine, astronomy, navigation, and new concepts of world geography and philosophy. The popularity of Moorish scholarship was such, that for centuries Arabic was commonly accepted as the language of scholars from Europe, Asia and Africa, and the Moorish intellectual centers in Toledo, Cordova, Seville and Granada became Meccas of learning (1992, p. 254).

Carew's analysis of the development of the Islamic intellectual tradition emphasizes in this particular quote the transmission from and through Africa, and through the Moorish culture that flourished in North Africa and Spain, research and scholarship that ultimately would bring Europe out of its Dark Ages. The central location of Muslim strongholds in the Near East and Egypt facilitated the creation and sustenance of a vast network of scholars who could publish and exchange works from China in the east to Spain in the west. The immensity of this empire also provided the context and conditions for the emergence of an Arabic ethnographic tradition and furnished the opportunity for Arab scholars, travelers and geographers to contrast and compare a vast array of human societies and cultures. Using the earlier scientific works of the ancient Greeks rediscovered in Egypt and translated into Arabic mostly by non-Arab scholars, Muslim writers developed a standard ethnological discourse pertaining to "blacks" and “others." Arabic ethnological discourses, combined with additional source materials from travel tales, slave traders' manuals, and folklore, comprised a popular literary genre devoted to mirabilia (accounts of the fantastic) that circulated widely among Islamic literati. Mirabilia reflected a taste for exoticism and tall tales, but contributed 
nevertheless to the Arabic ethnographic conventions that emerged after the eight century

(Al-Azmeh, 1992, p. 5).

Aziz Al-Azmeh in his article, Barbarians in Arab Eyes, examines and details how Arabs "construed that consummate emblem of otherness and exoticism which is the barbarian" (1992, p. 3). Al-Azmeh uses the term barbarian to present and represent a set of complex ideas governing the objectification of the objectified "other" in the social construction of difference. He defines and describes this cultural mode of identity formation as follows:

States, civilization and cultures expend much energy, not commensurate with size, fixing moral boundaries, consolidating their difference from outsiders, and otherwise encircling themselves with frontiers impermeable to the exotic; and this energy intensifies in circumstances of commotion, instability and conflict, turning to a frenzy of positive hostility most dramatically represented by theoretical and practical racism. It is unclear why the internal cohesion of historical masses and their construction of identities appear to be sustained by exclusivity as if by a force of nature, but it is demonstrable that a sense of normality, continuity and affinity is invariably sustained by conjuring contraries and indices of difference. For it is the case that these historical masses do not theorize ethnological difference, but rest upon inverting the normal self and construing the other as pathological (Al-Azmeh, 1992, p. 3).

Al-Azmeh's suggestion of a natural tendency in human societies to construct social identities which in turn produce racial theories and racist practices that define and sustain cultural "normality, continuity and affinity" falsely assumes that what may be common in recent "historical" experience is true in the totality of human existence. Consequently, al-Azmeh's analysis is presented here specifically to address the Islamic mode of constructing self and 'other,' and not as a paradigm of racial theory. Barbarism, after all, is a term fraught with terminological problems, and is clearly a matter of the "eye of the beholder." The nomadic Arab tribes that swept out of the Arabian Peninsula in a frenzy of jihad most likely appeared as "pathological" barbarians to the urbane 
cultures they conquered and dominated. This irony seems to have escaped Al-Azmeh's attention, although he is mindful of just such a viewpoint expressed in Eurocentric studies of Arabs and Islam in the last two centuries (1992, p. 3). In establishing the cognitive roots of Arabic ethnography, Al-Azmeh also argues: "Religion played little or no role in this construal of the other, except in so far as the inversion of normality implies an absence of religion properly speaking, or barbarous forms of idolatry and animism" (1992, p. 4). His use of the terms "idolatry" and "animism"—in minimizing the role of religion (Islam) in the construction of Arab ethnological discourse-reveals his own monotheistic bias or conception of "normality." In a similar vein he insists: "The topoi and cognate representatives of others were shared by Muslim and non-Muslim authors alike" (Al-Azmeh, 1992, p. 4). The cross-cultural presence of ethnic stereotypes-the fact Muslim and non-Muslim authors "shared" them—in no way supports the contention that they were somehow devoid of religious context or content. Instead, their shared traditions of monotheism and the Mosaic distinction provided a common vernacular and idiom within which such negative ethnic notions about pagans and their cultures could evolve and gain currency. These criticisms aside, however, Al-Azmeh identifies and analyzes key concepts and texts that influenced the Arab perception of barbarism: the Greek notion of barbaroi; the Jewish notion of the goyim; well-known treatises by Pliny, Strabo and Galen; and the lesser-known work of Bardaisan, a Mesopotamian Syriac writer (1992, p. 4). Al-Azmeh excludes northern European influence from this confluence of ideas, and concludes: "Arabic authors imbibed notions that had been widely disseminated, orally and in writing, around the Mediterranean basin and in the syncretistic seats of Hellenistic, Iranian and Semitic trade and culture ... as well as from 
representations of direct Chinese and Indian provenance" (1992, p. 4). The juxtaposition

of these diverse ethnographic concepts with popular stereotypes and folklore that developed in the Arab world produced the complex and composite image of the barbarian in Arab eyes. But that image and its accompanying rhetoric ultimately came to be dominated by emerging scientific theories and thinking in Islamic culture. Al-Azmeh states:

Arabic ethnology, including the ethnography of barbarism, was governed by a natural-scientific ecological determinism mediated through the notions of humoral medicine. Briefly stated, medieval Arabic culture followed the Greek conception of the inhabited world as consisting of seven latitudinal zones that began slightly north of the equator and ended in the realms of perpetual darkness in the north. Beyond the zones (aqualim, from the Greek klimata) human habitation was not possible, and within their boundaries the nature of the changing environment prescribed different temperaments to the inhabitants. The four primary qualities of dryness, humidity, heat and cold, that attached to the four elements, entered into four combinations that yielded the basic somatic humours of blood (hot and humid), phlegm (cold and humid), bile (hot and dry) and atrabile or black bile (cold and dry). Embryonic growth was the result of the "cooking' together of these four humours (1992, p. 6).

The notions of humoral medicine described above figured heavily in Muslim experimental science, particularly chemistry and alchemy, and, through the global dissemination of Islamic scholarship, entered the West and influenced the development of science in Europe. The rediscovery in Egypt of the works of Galen, a second century C.E. medical authority who lived for a while in Alexandria, provided a conceptual framework for Arabic ethnology, especially the ethnography of barbarism as applied to "black" peoples. Galen posited ten traits purportedly characteristic of African "blacks" that in addition to blackness of skin included: "kinky hair; thin or sparse eyebrows; wide nostrils; thick lips; sharp, white teeth; 'chapped' hands and feet; an offensive odor; eyes with large black pupils; inferior intelligence; and an oversized penis" (Davis, 1984, p. 
42). The notion that "black" penises could be typically "oversized" says much about Hellenistic concepts of somatic normality, and perhaps contributed to the pathological need of medieval Muslims to castrate "black" males. Penis size and the other stock elements of Galen's infamous laundry list of "black" traits formed a constellation of stereotypes that operated in tandem with Muslim theories of ecological determinism to produce a "scientific" paradigm of "black" identity—or what later has come to be known as "scientific racism." The Islamic scholars who innovated and eventually canonized this literary convention rejected the explanation of "black inferiority" suggested by Noah's curse and sought instead—like many Enlightenment-era scientists and scholars of Europe centuries later-to explain and justify their beliefs in black "disnature" and intellectual incapacity through the natural phenomena of climate and environment. Ibn Khaldun (d. 1406) the famous Tunisian-born historian who also lived in Egypt, categorically rejected Noah's curse as an explanation for the origins of "blackness." His famous work the Mukaddima challenged and contested Muslim and Jewish writers who ascribed to this widespread theory as follows:

Certain genealogists, ignorant of the nature of things, imagined that the Sudan, who are the descendants of Ham b. Nuh (Ham, son of Noah), are set apart (from other men) by their black color as a result of the curse (which Noah) laid upon their father Ham. According to them, Ham's black color as well as his slave condition were decreed by that curse of God. Noah's malediction of his son Ham is reported in the Tawrat (Torah). In that book this is not at all a question of black color. The curse has no other aim than to make Ham a slave of his brother's descendants, and that is all. To connect the black color of the Sudan with (the curse laid upon) Ham is to fail to understand the nature of heat and cold, and of their influence on climate and on the condition of animal life (cited in Sollors, 1997, p. 91).

Ibn Khaldun took the Greek term "Ethiop" (meaning, "burnt face") at face value, and championed an environmental explanation for the apparent differences in human 
phenotypes. But he and his scientific-minded colleagues also used environmental theories to explain and rationalize what they claimed were congenital cognitive deficiencies, behavioral abnormalities, and physical defects in "blacks" (and in northern Europeans) (Dover, 1952). The Greek theory of seven latitudinal zones of human habitation ascribed different temperaments to each zone's inhabitants. This template of human geography assigned the first zone to the equatorial regions and described it as barely habitable due to excessive heat (B. Isaac, 2006; B. H. Isaac, 2004). Arabic writers found in this paradigm a ready explanation not only for the physical appearance of "blacks" (and others), but also for their behavior. Thus the sun, which was deemed responsible for a catalog of psychosocial pathologies and physical deformities in the tropics, made "blacks" erratic, cunning, lascivious, over-sexed and incapable of learning because their brains retained little humidity due to excessive heat. Additionally, their snub noses, big lips, bug eyes, burnt skins and big penises caused them to resemble in appearance and habits the animals that shared their environment. In the Arab mind these combined characteristics constituted the types of human beings who were "consummately barbarous." Thus the extreme environmental conditions in these zones of habitation--whether in the extreme north or south--produced extremes in human disnature, temperament and appearance (AlAzmeh, 1992, pp. 7-11). Al-Azmeh summarizes the manner in which such statements appeared in Arabic texts as follows:

This fashioning of ethnological stereotypes through natural scientific determinism coexisted, without any apparent sense of unease, with detailed ethnographic descriptions of various African and northern societies, not only in the same cultural ambience, but also within one and the same text, where ethnological typification and ethnographic description served different purposes. This was particularly the case with peoples having territorial states, which caused the Ethiopians to be regarded as the most exalted of Negroes - so exalted, indeed, that it was from them that kings chose their eunuchs, thus underlining power 
relationships which underpinned ethnological types locally in Muslim domains and at large in a world organized by and for these domains (1992, p. 12).

Neither "whiteness" nor "white" people seem to have attracted the kind of intense intellectual preoccupation or social animus in the Arabic mind as "blacks." Lewis identifies Banu'l-Asfar, which means "sons of the yellow [one]," as the term used in medieval Arab texts "to designate the peoples of Europe" (1982, p. 141). Apparently this label, which the ancient Arabs first applied to Greeks and Romans, later expanded to include "the natives of Spain and then to Europeans in general" (Lewis, 1982, p. 141). The term is derived from biblical genealogies. Asfar, the grandson of Esau, is the father of Rumil the purported ancestor of the Greeks and Romans (Rum). The following observation from Lewis about the rhetorical use of Banu'l-Asfar reveals a crucial distinction in the Muslim social construction of "blacks" and "whites":

Some scholars have explained the terms as referring to the lighter skin color of the Europeans, seen as yellow, i.e., blonde, in contrast to the brown and black of Africa and Asia. This seems unlikely. Arab and Persian authors usually call whites, white, not yellow. Moreover they rarely speak of Europeans in terms of race or color. While aware, sometimes sharply, of the contrast between themselves and their darker-skinned neighbors to the south and east, they attach much less importance to the somewhat lighter complexions of their neighbors to the north (emphasis added) (1982, p. 141).

Derogatory references to Europeans did appear in association with the ethnic stereotypes prescribed according to the theory of seven latitudinal zones of climate and environment. Terms like "blanched" and "leprous" in Arabic ethnography convey a contemptuous view of the skin color of northern European groups. Nevertheless, the crucial point to be gleaned from Lewis's comment above is that "whites" were mostly exempt from notions of "racial" difference because "whiteness" itself did not generally constitute a separate category of identity in the Muslim mind but was viewed instead as 
the normative human condition or state. Given this orientation "whites" could be barbarians, but as Al-Azmeh puts it: "they were merely barbarous, and not consummately barbarian" (1992, p. 7). Unlike "blacks," they could overcome their social and moral deficiencies if given the proper socialization and religious training.

Although the rhetoric expressed by Arabic ethnographers went a long way in laying the foundation for the emergence of modern racist thought, Muslim scholars, unlike their later Euro-American counterparts, never developed the concept of polygenesis (the theory that "blacks" evolved separately) to explain the purported savagery and barbarism of Africans. Their strict adherence to the Quranic teachings that all humans descended from a single soul prevented them from questioning the underlying unity of the human family. Yet what Arabic writers like Al-Idrisi, Said al-Andalusi, Ibn Khaldun, Al-Masudi, Ibn Battuta, Ibn al-Faqih, Nasiri al-Din Tutsi and others said about "blacks" could provide a primer for Racism 101, and did, in a sense, for the masses of literate Muslims and non-Muslims educated in the Islamic world. Arabic ethnographic discourse was disseminated throughout the Islamic empire in the form of $a d a b$-urbane secular Arabic writing that included history, geography and popular literature. According to Al-Azmeh: "Adab was the means of cultivating a common cultural identity, and the mirror-image of this identity and its shades, which was barbarism in its many gradations, was a mode in which exclusion buttressed and sharpened the social boundaries of a reflexive culture" (1992, p. 18). What Al-Azmeh benignly refers to as "the social boundaries of a reflexive culture," hardly describes the religious ideology and ethnocentric ethos that dictated and governed the social constructions of "self" and "other" in Islamic society. Through the literary vehicle of $a d a b$, Arabic writers 
popularized and institutionalized stereotypic notions of "black" barbarity that eventually became widely adopted tropoi in Western literature. Arabic ethnography infiltrated European thought through the internationally renowned centers of learning in Moorish Spain. Carew states: "At the zenith of Moorish power, al-Andalus [Spain], that land of many cities, attracted scholars from England, France, Germany, Italy, the rest of Europe, as well as from distant parts of the Muslim empire" (1992, p. 258). The translation and dissemination of Arabic ethnographic discourse throughout Europe from the widely studied and imitated corpus of Arabic literature provided an intellectual foundation and impetus for the development of antiblack racism and Eurocentrism in the late medieval and early modern eras.

Imperial power gave Arabs the opportunities to transform themselves from "barbarian" hordes into sophisticated and urbane global entrepreneurs and purveyors of Islam. Like the Greeks and Romans who ruled vast empires before them, Arabs conquered those who became their teachers. Unlike their predecessors, however, they used religious ideology and military prowess in tandem to establish a slaveocracy partially based on race. Thus the Islamization of the African slave trade constituted a decisive step toward the establishment of a pigmentocracy—the kind of racially structured slave society that became a fixture in the New World.

Issue (3) - the role of the Arabic slave trade in Africa and in the Islamic construction of race-also, of necessity, has been dealt with in some detail in the sections above. A few points need amplification in addressing how Islamification of the slave trade led eventually to the racialization of slavery. Muhammad, who according to tradition owned slaves, explicitly rejected color prejudice in a number of widely quoted 
remarks attributed to him. Muslims, however, often expressed attitudes and beliefs that did not conform to his teachings and strictures. And, as the Islamic slave trade in Africa shows, even "dark-skinned" Muslims frequently found themselves subjected to captivity, sale and forced servitude in contravention of Quranic tradition. The terms Arabs used for slaves also denoted color consciousness and racial distinctions. In medieval times the term abd designated "black" slaves, while mamluk—-an Arabic word meaning 'owned"”-became the typical appellation for white slaves (Irwin, 1977, p. 127). Eventually $a b d$ came to represent a "black" person whether enslaved or free. In North Africa and Moorish Spain, khadim, a word that means servant, commonly was used to refer to "black" slaves or concubines (Irwin, 1977, p. 127). Thus a lexicon developed to differentiate amongst the millions of slaves of diverse ethnic origins that entered the newly acquired Muslim empire. These labels demonstrate that slavery was never exclusively identified with "blackness" in the Muslim world, as it would be later in the Americas. Nevertheless, Muslims made clear and crucial distinctions in the treatment and employment of "black" and "white" slaves. The practice of totally castrating black males for the slave market versus the partial castration of "whites," furnishes a salient example. More importantly, "black" slaves typically filled the most menial, onerous and dangerous positions in the Muslim work force. Other than domestic work, "black" slaves labored in mines, on plantations and in the military. Slave soldiers served in various parts of the Muslim world, and were of particular importance in the Islamic conquest of North Africa (Brunson \& Rashidi, 1992; Pipes, 1980). Slavery in the Islamic world generally followed the ancient precedent and dubious distinction of being an equal-opportunity enterprise, but, as the numbers of "white" slaves declined and "blacks" became the vast majority of 
Islamic slaves, the degradation, debasement and servility associated with slavery acquired a black face and a black identity.

Issue (4)—the "mulatto problem"—introduces a critical psychosocial and political component in the development of "black" identity that is central to understanding the construction of "race" in the Islamic world and in the West. The Afrocentric historian Chancellor Williams coined the term and defined the "mulatto problem" in The Destruction of Black Civilization (1974), a classic work of twentieth century black scholarship devoted to establishing a new approach to African studies. Williams' writings resonate with racialist concepts that reflect his vindicationist mission as a "black" historian. Although he generally treats race as a sociohistorical phenomenon rather than a biological fact, his ambition to place "blacks" "center stage—into their own history ..." often results in his use of essentialist theories and rhetoric (1974, p. 45). This Africancentered approach and agenda dominates his discursive strategy and rhetorical style, as evidenced by this passage that locates the roots of the "mulatto problem" in the Asian invasions and conquests of Egypt:

The invading conquerors not only capture and control all political and economic power by military might, but, even though they may be nomadic barbarians, they generally claim to be from a higher civilization and, therefore, reinforce the myth of being superior in fact, and not just because of military conquests. Even if no such claim is made, the new ruling classes and all members of their race are superior vis-à-vis the indigenous or conquered people.... This meant that even in the beginning, "siding with the Asians" was not solely determined by whether one was a half-breed or full-blooded African.... Indeed, so anxious were some of these early Blacks for "integration" with the Asians that they themselves did most in creating the new breed of Egyptians who were to become their mortal enemies. For in an all-out effort to appease the invaders they freely gave their daughters and other desirable females as gifts to become concubines, thus speeding up the reproduction processes on an ever-widening scale. Nor did this lessen the wholesale capture of women in raids on African villages for the same purpose and for export to Asia (C. Williams, 1974, pp. 76-77). 
To appreciate Williams' remarks in context it is necessary to ask the question: If not military might, what actually comprised and justified the Asian conquerors' claims of superiority or compelled Africans to seek "integration" with their invaders? Before the rise and spread of monotheism in the Near East, Africans in Egypt shared a common cosmotheistic worldview with the Assyrians, Persians, Greeks and Romans who, in succession, conquered vast areas of the Nile Valley. Thus the notion that "my god is true and yours is false" did not contribute to the conception or perception of superiority or of other presumed differences between non-African invaders and the Africans they conquered and ruled. We need to look elsewhere, then, to understand the cultural differences that figured in this process and how they operated in alienating Africans from their own ethos. The Senegalese scientist and historian Cheikh Anta Diop in The Cultural Unity of Black Africa posits a "two-cradle theory" to account for "certain non-essential relative differences among peoples" (1978, p. 9). Diop defines and locates his "southern cradle" of socialization as follows:

[...] the Meridional cradle, confined to the African continent in particular, is characterized by the matriarchal family, the creation of the territorial state, in contrast to the Aryan city-state, the emancipation of women in domestic life, xenophilia, cosmopolitanism, a sort of social collectivism having as corollary a tranquility going as far as unconcern for tomorrow, a material solidarity of right for each individual, which makes moral or material misery unknown to the present day; there are people living in poverty but no one feels alone and no one is in distress. In the moral domain it shows and ideal of peace, of justice, of goodness and an optimism which eliminates all notion of guilt or original sin in religious and metaphysical institutions. The types of literature most favored are the novels, tales, fables and comedy (1978, p. 195).

Diop confines his "northern cradle" to Greece and Rome and argues that the patriarchal family, the city-state and xenophobia constitute the distinguishing characteristics of this category. He goes on to state: 
An ideal of war, violence, crime and conquests, inherited from nomadic life, with as a consequence, a feeling of guilt and original sin, which causes pessimistic religious or metaphysic systems to be built, is the special attribute of this cradle. Technical progress and modern life, the progressive emancipation of modern women under the very influence of this individualism, so many factors make it difficult to recall the ancient condition of servitude of the Aryan woman. The literary style par excellence is tragedy or drama. The African, since the agrarian myths of Egypt, never went beyond the cosmic drama (Diop, 1978, pp. 195-196). Although Diop confines the northern cradle to Greece and Rome, elsewhere in his

presentation he discusses Western Asia as the "zone of confluence or meeting place of the two cradles, that which has been most bitterly disputed between the two worlds" (1978, p. 94). Arabia falls within this zone. Citing similar data used by Drusilla Dunjee Houston (1926) in her classic Afrocentric text, Diop speaks of Arabs as resulting from the intermixture of northern and southern elements with the northern nomadic culture, "accompanied by the dominance of the patriarchal system," triumphing over the southern or "Cushite" customs and traditions (Diop, 1978, pp. 94-100). It is northern nomadic culture that brings Arabia under the purview of Diop's northern cradle, and provides the Arab invaders with customs and traditions that came into direct conflict with the indigenous African societies they conquered.

Theories of patriarchy and matriarchy—based mainly on the work of nineteenth century scholars J. J. Bachofen, Lewis Henry Morgan and Friedrich Engels-figure foremost in Diop's formation and analysis of his two general categories of socialization. According to those theories, early human groups defined relationships and traced their lineage through the female line, through motherhood, and this in turn became the central mechanism for determining social structure, social status, marriage arrangements and the transfers through inheritance of property, rights and honors (Bachofen, 1926).

Motherhood and the prominent social status of women came first because the male role in 
procreation remained largely unknown to early human groups. Diop, with customary caution, delineates and examines these arguments against a broad array of psychological, ethnographic and sociological data, pointing to inconsistencies, anachronisms, fallacies and analytical errors before placing them in the context of his own views. He categorically rejects the idea that "the participation of the father in the conception of the child" was totally unknown, and argues that it was viewed as "secondary and less operative than that of the mother. He states: "While it is known that the father does supply something, the identity of the child and the mother is a matter of conviction" (Diop, 1978, p. 41). In African American parlance, the saying goes: "Mama's baby, daddy's maybe."

Robert S. McElvaine in Eve's Seed: Biology, the Sexes and the Course of History (2001), using an approach he calls "biohistory," explores the effects of gender roles and misperceptions about sexual difference on human cultures over the last 10,000 years. McElvaine posits the discovery of paternity as follows: "At some point during the development of agriculture and animal husbandry, probably as a result of the observation of kept animals, people began to more fully perceive the male role in procreation ..." (2001, p. 122). With paternity established as a biological fact, social structures gradually changed to reflect male centeredness or dominance in human reproduction as patrilineal customs emerged around the new organizing concept of biological fatherhood. Ironically, the discovery of paternity did not result in an understanding that males as fathers and females as mothers jointly created their offspring. Instead, the notion developed and proliferated that the male "planted" semen ("seed," in Latin) in the female's womb, which, without any genetic contribution from the female, was then brought to parturition. 
McElvaine labels this dualistic view of procreation the "conception misconception," and argues that the radical shift from a "woman-born" to a "male-born" paradigm for human reproduction is the subject of numerous myths in the ancient world (2001, p. 122). The well know story in Genesis of Adam and Eve, which first appeared in written form sometime after $600 \mathrm{BCE}$, presents a typical example of the "male-born" paradigm, sacralized and rendered as holy writ. Eve's emergence from Adam's womb (rib) established a mythic typology for male reproduction. In Greek mythology the goddess Athena springs full-grown from Zeus' forehead and is thusly "fathered." The Greek playwright Aeschylus (circa 525-456 BCE) in The Eumenides has Athena proclaim: "There is no mother anywhere who gave me birth" (cited in McElvaine, 2001, p. 125).

The "stage-theory" upon which nineteenth century concepts of matriarchy and patriarchy depended — the idea that all human societies passed through a universal matriarchy (female-dominated society) before becoming patriarchal—has been widely discredited along with the utility of the concept in explaining social development. Diop rejects the classical theory of a universal matriarchy in a chapter devoted to that issue (1978, pp. 25-54). But the terms matrilineal and patrilineal-defined as inheriting or determining descent through female and male lines-accurately reflect and denote gender-based lineal systems that functionally distinguish human societies around the globe. Diop generally identifies and locates matrilineal customs in his southern cradle and patrilineal customs in the northern cradle, and argues that these opposing forms of descent and inheritance owe their divergent evolutionary development and expression in part to different environmental conditions in the two zones. This idea of environmental causation is somewhat reminiscent of the Greek theory of seven latitudinal zones, and 
Diop's modeling of this concept brings to mind methods of Arabic ethnology discussed earlier. The point of this digression, however, is not to speculate as to causation but to uncover the cultural mechanisms by which the conquerors of African lands could assert their purported superiority over the conquered. Both Diop (1978) and Williams (1974) agree that the invaders of Africa came with patrilineal systems of inheritance and descent that provided a sharp contrast to the matrilineal structures that remained integral features of many African societies. This is not to say that outsiders introduced patrilineal systems to Africa. The discovery of the male role in procreation, as McElvaine argues, is connected to animal husbandry, a mode of food production that appeared in Africa in the Neolithic period sometime after 9000 B.C.E. But the shifting emphasis from the female to the male as the "creator" of new life possibly followed a shift in agricultural production from female labor to male labor brought about by the invention of the plow around 4000 BCE (McElvaine, 2001, pp. 119-134). These changes in food production altered concepts of human reproduction, and males, the newly self-proclaimed creators of both human life and the food that sustains it, gradually began to assert their authority as fathers over their children, and — to assure paternity—as husbands over their wives. These lines of dialogue excerpted from The Eumenides by Aeschylus, and articulated by the Greek god Apollo, furnish a later example of this ancient male concept of procreation:

The mother is no parent of that which is called her child, but only nurse of the new-planted seed that grows. The parent is he who mounts (cited in McElvaine, 2001, p. 119).

This revolutionary notion of fatherhood radically changed pagan religion. Father gods made their dramatic appearance in the ancient world, reflecting the new male 
procreative role on a cosmic scale. Eventually, with the advent of the counterreligion and its subdistinctions—Judaism, Christianity and Islam—the male became the dominant theomorphic form; god lost its feminine face and characteristics and became "our father who art in heaven." But such changes took place gradually and unevenly throughout the world. As McElvaine notes:

Much as the knowledge that seeds produce plants appears to have existed thousands of years before a whole new way of life based upon that understanding was instituted, knowledge of a greater male role in procreation probably existed for a long time before a whole new way of life based on this (mis)understanding was instituted" (2001, p. 123).

With McElvaine's point in mind, it seems that social structures and modes of production in Africa created conditions that enabled women to retain greater control over birth and birthrights during the early evolution and development of patrilineal customs. Although the reification and deification of fatherhood followed the discovery of paternity in Africa, as was the case elsewhere, feminine attributes of the cosmos were well integrated into African cosmotheism and were not easily supplanted. For this and other reasons African women continued to enjoy a higher degree of freedom and independence from male dominance than their counterparts in neighboring regions. Egyptologist Gay Robins in Women in Ancient Egypt summaries this point rather well in her comments on the status of women in Egypt's New Kingdom era:

Not only could women inherit, own, and dispose of property in their own right, they could enter into business deals, and they could go to court as plaintiff, defendant or witness, on an equal footing with men. In contrast to some cultures, a male guardian was not required to act for them (1993, p. 136).

Robins is quick to point out that her findings refer to upper-class Egyptian women who had wealth and family status to back them in the event of business or legal problems. Nevertheless, the general consensus of the status of African women in the ancient world 
is that they enjoyed far more freedom than their sisters in the Near East and Europe-a fact underscored by the evidence of their reigns as pharaohs or queens over powerful states in the Nile Valley. Invasion and conquest, however, dramatically changed the gender status quo along with the ethnic make-up of North African populations. Williams notes these changes as follows:

Intermarriages between conquerors and conquered continued along with concubinage as a national institution. The direct result was that more and more Egyptians became lighter and near-white in complexion. In short, they did in fact become more Asian in blood than African. Yet this upper ruing class of nearwhites was at no time more than a fourth of the population; for until the Islamic "flood" which began in the middle of the seventh century A.D., the vast majority of the Egyptians were what modern scholars like to characterize as "Negroid" (1974, pp. 77-78).

Differences between the conquerors and the conquered in the social status of women, the social meaning of paternity, and related gender issues, provided the context and opportunity for the conquerors to reify the distinctive features of their ethos into the trappings and accoutrements of a "master race"- to borrow Williams' term.

Intermarriage and intermixture made "black" women key figures in the establishment of this new cultural regime and social consciousness in Africa through a "one-way sexual process" that brought them under foreign influence and control. The process was "oneway" for the obvious demographic reasons that the armies of foreign conquerors were male, and more importantly, as Williams asserts:

The "master race" always kept its own women "sacred" and secluded behind the walls of their homes. They were not allowed to go outside except under guard. African women had no such restrictions or protection. They were fair game for men of all races, and for them it was always open season.... The "master race," then, while loudly proclaiming a strange doctrine of "racial purity" for itself, has been the world's leader in bastardizing other peoples (1974, p. 77). 
At no point in Williams' exegesis of the "mulatto problem" does he portray Africans as merely the passive victims of foreign aggression. Not only does he cite examples of imperialist wars initiated by Africans, he also argues that Africans were complicit in their own subjugation through their acceptance and support of an ethnic status quo determined in part by patrilineal descent. Williams argues convincingly that the template for this process was established in Ancient Egypt when the offspring of Asian males and African females rejected the ethos and customs of their mothers in favor of their foreign fathers' culture:

These fathers recognized them ... And since they claimed superiority over the Africans, their half-African offsprings considered themselves to be a superior breed also. These Afro-Asian offsprings were given preferential treatment, positions of authority, wealth according to the status of their patrilineal family, and an education that could draw on Asian culture as well as the highly advanced African civilization in Upper Egypt and southwards to the "Land of the Gods" (1974, p. 78).

The fact that the majority of " "black" mothers' were concubinary slaves undoubtedly shaped the attitudes of their "half-breed" children towards their mothers' culture (C. Williams, 1974, p. 78). On their mothers' sides of their families, these children were born into a servile or conquered class. But slave mothers had no control or claim over their sons and daughters; the children of such unions belonged to their Asian fathers who, according to Williams, "could and generally did consider them as free-born due to their Asian blood" (1974, p. 79). Conquest and the cultural and gender conflicts and compromises that accompanied the intermixture of native and foreign peoples produced over the centuries a "mulatto" population deeply indoctrinated in the concepts of the innate superiority of their Asian fathers and willing to assist in the advance of Asian culture into Africa. Williams locates the roots of the "mulatto problem" in Egypt, 
but extends his analysis of the phenomenon into later periods of African history and other regions of the continent. Most important for this discussion, Williams uses the "mulatto" paradigm to explain the social consequences of the Arab invasions of Africa in the middle seventh century:

And the same ethnic phenomenon that accelerated the process of racial disintegration in Egypt also operated in the Sudan. This was, simply stated, the widespread sexual activities on the part of Arab men and Black slave girls, the outcome of which was a new breed of Afro-Arabs - the same sexual process that produced "Egyptians" as a nationality group neither Asian nor African. In the Sudan Arabization and Islamization had another outcome: Not only did the AfroArabs consider themselves Arabs and bitterly resented being called Sudanese (Black) but thousands of the jet-black, unmixed Africans insisted on being classed as Arabs. They still do... (1974, p. 165).

The avowed desire to be anything but "African" reminds me of Lewis R.

Gordon's axiomatic statement on racist ideology in his insightful essays on neocolonial racism: Her Majesty's Other Children. Gordon defines the "two dominant principles of racist ideology" as follows: (1) be white, but above all, (2) don't be black" (1997, p. 63) Gordon goes on to say: "We can call the first the principle of white supremacy; and we can call the second the principle of black inferiority" (author's italics) (1997, p. 63). Gordon's principles of white supremacy and black inferiority seem apposite and applicable to the social effects of the "mulatto problem" on the construction of "black" identity, even though, at this particular sociohistorical juncture, racism, in the modern sense of the term, did not exist. But in Williams' analysis and Gordon's axiom we have a basis for understanding how foreign invaders - using gender and ethnic conventions initially born out of conflict and conquest and later given a religious etiology and impulse — created a predatory pattern of cultural aggression that in turn made it possible for Africans to be divided and conquered from within. 
The emphasis on acquiring female concubines in the Islamic African slave trade continued and expanded the ancient pattern and practice of exploiting "black" female sexuality. It also created and sustained a large "mulatto" population in Africa and elsewhere in the Islamic world. Arabs mixed with non-Arabs throughout the Islamic empire, but due to their visibility Afro-Arabs "were more exposed to abuse and discrimination" (Irwin, 1977, p. 125). Irwin states: "'Son of a black woman" was a not infrequent insult addressed to such persons, and "son of a white woman" was accordingly used in praise and boasting" (1977, p. 125). The overt character of this type of Arab ethnic chauvinism influenced and encouraged "half-breeds" to detest and discriminate against "unmixed" Africans. It also explains the kind of self-effacing literature written by "blacks" in Muslim societies that featured half-hearted defenses of their African ancestry and appearance. Segal cites as an example two poems attributed to Suhaym, an African slave who died in $660 \mathrm{CE}$ :

If my colour were pink, women would love me But the Lord has marred me with blackness.

Though I am a slave my soul is nobly free

Though I am black of colour my character is white (quoted in Segal, 2001, pp. 46-47).

Africans and Afro-Arabs in Arabia, from the beginnings of Islam and earlier, responded as best they could to the prejudices that confronted them in every day life. Among the early Arab writers of mixed descent, the work of Uthman Amr Ibn Bahr AlJahiz (778-868), a Muslim scholar from Basra, stands out for its originality and controversial claims. A prolific author whose two hundred titles spanned subjects in theology, anthropology, zoology, philosophy and linguistics, Al-Jahiz has been credited as the founder of an Arabic prose style which bears his name and as the foremost Arab 
scholar of the ninth century. In a controversial book titled The Book of the Glory of the Blacks (1981), Al-Jahiz challenged and contested the racial prejudices prevalent in the Islamic world of which he was perhaps a popular target given his dark skin and uncommonly large eyes (Jahiz is a nickname that means "bulging eyes" in Arabic). Using the adab style of Arabic prose, he composed a scholarly defense of "blackness" and "black" people that included in its recitation the claim that the Prophet Muhammad, his father Abdullah, and his grandfather Abd Al-Muttalib were all "blacks" (Al-Jahiz, 1981, p. 50). In a wide-ranging discussion of Arabic history, culture and literature, presented in the form of a letter, Al-Jahiz also introduces dozens of other prominent blacks from the pre-Islamic and Islamic eras. And, in a demonstration of rhetorical hubris that prefigures post-colonialist and Afrocentric discourses on Eurocentrism and white supremacy, AlJahiz divides human populations into two categories, whites and non-whites, and includes anyone who is not white as part of a silent and culturally superior black majority:

The number of Blacks is greater than the number of Whites, because most of those who are counted as Whites are comprised of people from Persia, the mountains, Khurasan, Rome, Slavia, France and Iberia, and anything apart from them is insignificant. But among the Blacks are counted the Negroes, the Ethiopians, the Fezzan, the Berbers, the Copts, the Nubians, the Zaghawa, the Moors, the people of Sind, the Hindus, the Qamar, the Dabila, the Chinese, and those beyond them. The sea is more extensive than the land, and the islands of the sea between China and the land of the Negroes are full of blacks, like Sarandib, Kalah, Amal, Zabij, and its islands up to Hindustan and China, and Kabul and those coasts. The Arabs come from us - not from the Whites - because of the similarity of their color to ours ... The Hindus are more yellow in color than the Arabs, yet they are (counted) among the Black peoples. And the Prophet (God bless him and grant him salvation) said, 'I was sent to the Reds and to the Blacks,' and people already know that the Arabs are not red, as we mentioned before. That is our glory and that of the Arabs over the Whites, whether they like it or not. And if they hate (to admit) it, it is still our glory in what we have mentioned (here) over all (Al-Jahiz, 1981, pp. 55-56). 
Al-Jahiz traveled extensively but spent most of his years in Baghdad. As one of the pre-eminent scholars of his day, located in one of the great centers of learning in the Muslim world, his provocative work must have aroused great interest and attention. Contemporary scholars Graham W. Irwin, Bernard Lewis and David Brion Davis see AlJahiz's text “as a parody of Shu'ubiyya tracts [written by Persians and other non-Arabs who resented Arab privileges], intended to throw ridicule on Persian pretences by advancing similar arguments on behalf of the lowly and despised Zanj" (Davis, 1984, p. 44). Black scholars J.A. Rogers (1946) and William Preston recognize al-Jahiz's satirical wit, but find no fault with his intentions or historical perorations. Preston, who commissioned a recent English translation of The Book of the Glory of the Blacks, specifically takes Irwin to task for claiming that it "cannot be taken at face value" (Preston, 1981, p. 65). Preston's criticisms notwithstanding, Irwin does point to examples in al-Jahiz's other writings where he denigrates the Zanj, an East African people who figured prominently in the Arab slave trade. Irwin reasons:

Perhaps, in selecting the Zanj as his exemplar of baseness, he was trying, under cover of satire, to disassociate himself as much as he could from the inhabitants of a continent where all men were black and to which, ultimately, he owed his dark skin. That he should feel the need to do so is in itself a wry commentary on what it was like to be educated, admired, and famous - and yet part-African - in the medieval Muslim world (1977, p. 117).

Without wading in on either side of the controversy regarding Al-Jahiz's intentions, I believe his work, satirical or not, reflects the kind of rhetorical and discursive gymnastics Afro-Arabs performed to avoid or deflect the taint of "blackness" and servility associated with their African mothers (an Abyssinian mother in Al-Jahiz's case) from themselves. This headlong psychological retreat from African ancestry typifies the "mulatto problem" as defined by Williams and its enduring effects on the 
social construction of "black" identity within and outside of the African continent. It is to developments outside Africa, specifically in the Iberian Peninsula, that we now turn our attention. For there, in Westernmost Europe, a strategic confluence of the counterreligion (Judaism, Christianity, Islam), "black" slavery, and the "mulatto problem" took place, establishing the foundation for the emergence of modern "black" identity and the antiblack racism that accompanied it. 


\section{MOORS, TAWNY MOORS, BLACKAMOORS AND ARABS}

In the midst of what scholars in the West have labeled the European Dark Ages (the period between the end of classical antiquity and the dawn of the Italian Renaissance) a seemingly minor incident may have set in motion a momentous chain of events in world history. According to legend, the daughter of Count Julian the Orthodox Christian governor of Ceuta, a city on the Moroccan coast, was raped by King Rodrigo at the royal Visigothic court in Toledo (Spain) where she had gone at the King's invitation to learn the craft of lady-in-waiting. The young woman, Florinda, wrote and informed her father of Rodrigo's assault and implored him to rescue her. Upon retrieving his daughter from the Visigothic court, Count Julian vowed revenge on the King and his kingdom. As the owner of estates on both sides of the Mediterranean, Julian knew the country well. With his knowledge of the terrain and the oppressive conditions that prevailed in Spain under Visigothic rule, he approached Musa ibn Nusayr, the Muslim emir who governed North Africa, with a plan for invasion and conquest wrought out of vengeance and perhaps a healthy dose of opportunism. Musa, not yet exhausted from the grueling wars of North African conquest, already had conceived his own plans for Spain, viewing the Iberian Peninsula as a stepping stone in a series of jihads that would sweep across Southern Europe, lay waste to Rome, and secure the region for the glory and advancement of Islam. He welcomed Julian's assistance and perhaps exploited his anger 
in furtherance of his own ambitions. Whether Florinda existed in fact or as a figment of the imagination of later chroniclers of Moorish history, the Muslim invasion of Iberia was promptly organized and initiated. In April 711, a strike force led by a Berber general named Tarik ibn Ziyad crossed the Mediterranean and landed near the rocky promontory which now bears his name (Gibraltar, Jebal Tarik, "mountain of Tarik"). Commanding a small army of North African troops, Tarik, a former Christian, introduced Europe to the Muslim onslaught known as jihad. With the aid of Julian, and reinforcements from Morocco led by Musa, Tarik ended Visigothic rule in Spain and inaugurated through conquest a golden age of enlightenment and discovery that brought slavery, genocide, racism and religious intolerance following inexorably in its violent wake (Brunson \& Rashidi, 1992, pp. 54-56; Fregosi, 1998, pp. 89-95).

The Moorish conquest of Iberia received romantic and even hagiographic treatments in accounts written by Muslim chroniclers of the era, and by Washington Irving (1885) and Stanley Lane-Poole (1886), nineteenth century writers who popularized the topic in the West. Current scholarly approaches to this subject range from Richard Fletcher's revisionist critique of Andalusian history and culture in Moorish Spain (1992), to a recent work by Maria Rosa Menocal, The Ornament of the World: How Muslims, Jews and Christians Created a Culture of Tolerance in Medieval Spain (2002), that reintroduces the idea that al-Andalus (the name given the land by its Muslim conquerors) was an oasis of religious tolerance in the otherwise violent confrontations and conflicts between Islam and Christianity in Europe, Africa and the Near East. Black scholars and historians also have engaged in the romanticizing of this period and its players, operating from the reasonable conviction that the African origin of the Moors and their role as 
"bringers of enlightenment" to the Dark Ages of Europe has been ignored or dismissed by the West. To this end, it is common to find Stanley Lane-Poole's The Story of the Moors in Spain, which admittedly is among the first major studies of this subject to appear in English, quoted extensively in Afrocentric works despite the fact that LanePoole never addresses the subject with anything approaching an awareness of the larger issues concerning the African presence and influence in Europe. The works of W. E. B. Du Bois (1946), J. A. Rogers (1952), J. C. deGraft-Johnson (1954), and John G. Jackson (1970) typify twentieth century Afrocentric approaches to this topic, and have influenced the current generation of Pan African scholars. Those pioneers of black history, although scrupulously honest in their attention to and use of Arabic and other sources, operated with the intention of correcting the omissions of Western history and of setting the record straight about African cultural and intellectual achievements. In pursuing those goals they often did not situate Moorish culture within the larger context of Arabic hegemony and its promotion and expansion of color prejudice and racial slavery. Their groundbreaking studies, however, laid the foundations for the most comprehensive treatment of this topic to appear to-date: Golden Age of the Moor (1992), a collection of essays edited by Ivan Van Sertima as part of the series of publications known as the Journal of African Civilizations. In addition to Van Sertima's journal and the other sources cited above, studies by James H. Sweet (1997), Jack Forbes (1993) Jose Piedra (1993), and recent books by Maria Rosa Menocal (2002) and Richard E. Rubenstein (2003) also served as useful references for the discussions that follow.

The identity of the Moors, the principal players in the events that transformed Iberian culture and European scholarship, remains a matter of considerable debate. 
European scholars often have portrayed the invaders of Spain solely as Arabs, and have "whitened" them in an effort to omit or deny an African role in the conquest, colonization and enlightenment of Europe during this chaotic and formative period in its history. Inventing or employing terms such as "swarthy whites" or "dark-eyed whites" scholars like Joseph McCabe (1927) and Richard Brace (1964) assiduously followed the Eurocentric convention of "whitewashing" European history (Pimienta-Bey, 1992, pp. 188-189). Maria Rosa Menocal, on the other hand, sees Iberia as a melting pot of mixed ethnicities that started out as "white" and remained so after the Moorish invasion (2002). She contends the ancestors of a tenth century Muslim in Cordoba, "were as likely to be Hispano-Roman as Berber, or some measure of each, perhaps with smaller dollops of either Syrian-Arab or Visigothic, these latter two having always been the smaller but politically dominant groups" (Menocal, 2002, p. 28). Based on this scientific method of apportioning or conferring "dollops" of ethnicity, Menocal claims the members of the Umayyad dynasty who ruled tenth century Iberia from their Cordoban capital "were nearly all children of Christian mothers from the north," who consequently possessed "pale skin and blue eyes" that "were regularly remarked on by eastern visitors" (2002, p. 29). After his family's rulership over the House of Islam ended in Syria with a massacre by their Abbasid rivals, the Umayyad prince and heir Abd al-Rahman, grandson of the caliph, successor to the Prophet, and the spiritual and titular leader of the Islamic world, fled to the far western Islamic outpost of al-Andalus in 755 , fifty years after it had been conquered by the Moors, and there established himself, after a decisive battle, as the new ruler of the land. Abd al-Rahman was born from the union of a Syrian father and a Berber mother from Morocco, neither of which had to be "white" or "light-skinned." But 
Menocal's approach emphasizes the "Arab" and "Syrian" role in forming Andalusian culture and effectively minimizes ethnic and cultural influences in the peninsula that originated in North Africa. She asserts: "Arabness was the most aristocratic feature of ancestry one could want, and Syrian-Arabness was the venerable paternal line of Andalusian culture, both literally and figuratively" (Menocal, 2002, p. 29). Menocal never defines what she means by the term "Syrian" and regards the notion of Syrian "whiteness" as a matter of fact. Menocal also never uses the term "Moor," and treats "Berbers" as the appendages and mere functionaries of Syrian-Arab masters, or, when the Almoravid and Almohad Berber sects invade and seize power, as religious fanatics and foreigners who destroy the delicate balance of Andalusian religious tolerance. Menocal's persistent use of terms like "Arabization" and "Andalusian" in reference to the cultural transformation of Iberia, and without reference to the Moors, leaves as a glaring lacuna the questions of how and why this polity's founders came to be identified and known throughout Europe as Moors.

Lane-Poole, who wrote his history of Moorish Spain in the years leading up to the European partition and colonization of Africa, uses the term Moor to refer exclusively to the Berber populations of North Africa and Spain, thus distinguishing them from Arabs (Lane-Poole, 1886, p. 13n). Fletcher (1992) effectively ducks the issue of Moorish identity in the 175 pages of his treatment of Moorish Spain. Much of the confusion and disagreement surrounding Moorish identity seems to rest upon whether the Moors were Berbers, and who or what Berbers were before the seventh century Arab invasion and conquest of North Africa. It is common to find Berbers designated as "Caucasoid" in most anthropological texts. That "light-skinned" populations have had a significant 
presence in North Africa since antiquity is not in dispute. That all North Africans or even Berbers were in fact "white" or "light-skinned" during the era in question or at any other time in the region's past requires a kind of liberal application of the term that borders on racial hysteria. Given the double standard and social pathology with which the "one drop rule" operates in Euro-American psychology—one drop of "black" blood in the Americas makes a person "black" while one drop of white blood in Ancient Egypt or North Africa makes a person "white"-it comes as no surprise to find this kind of thinking dominating the historical treatment of this topic. The complexion of the North Africa's population no doubt underwent changes after the Moorish conquest of Spain. The mixing of Moors and Europeans in Spain, the importation of thousands of "white" Christian slaves into the Maghreb under the auspices of Moorish rule, and the expulsion of tens of thousands of Moors and Muslim converts from Spain and Portugal to North Africa in the fifteenth century after the Reconquest, must be considered important factors in the composition of the current populations.

That the Moors invaded Spain from North Africa is perhaps the only point of agreement among scholars regarding their origin and identity. In searching for their North African roots some have traced them to the Arabian Peninsula. Cheikh Anta Diop concurs with this finding as follows: "The Moors are Arabs, recent arrivals from Yemen, having come during the Islamic invasions (seventh century)" (1974, p. 200). Other Afrocentric scholars take issue with Diop on this point. Jose V. Pimienta-Bey (1992), Brunson and Rashidi (1992), and Wayne Chandler (1992), have sought the roots of Moorish culture among the Garamantes and other ancient populations of North Africa. While Diop's contention that they arrived in North Africa in the seventh century with the 
Arab invaders in no way suggests they were not phenotypically "African" in appearance (Diop cites an "African" origin for Arabs), other evidence does suggest the Moors were part of the indigenous population of North Africa, having emerged from ancient groups that roamed the Sahara for millennia(Diop, 1974). The late linguist Joseph Greenberg classifies Berber as a member of the Afroasiatic language family, and contends: "[it was] formerly spoken in all of North Africa except Egypt and the Canary Islands" (J. H. Greenberg, 1966, p. 75). Pimienta-Bey cites the work of a Moroccan linguist, Aziz Lofti, who posits a Kushitic origin of the Berber language, and contends that: "The Dra Valley of southern Morocco is largely regarded as having been inhabited long before the first Canaanite settlement of the 10th century B.C., by a Cushitic people whose descendants, the Haratins, represent one of the largest "Berber" speaking groups in Morocco" (1992, pp. 194-195).

Berbers, Moors, Tawny Moors, and Blackamoors, are common and sometimes interchangeable labels for these North African populations, despite the fact that all of them may have been devised and imposed by outsiders to describe them. Jack D. Forbes, whose analysis of the term "negro" figures decisively in this thesis, provides an excellent overview of the meaning of "Moor" in European usage:

The term more and its equivalents were widely used in late-medieval and early modern Europe. According to Simonet in his study of the language spoken by the Mozarabes (Christian Spaniards under Muslim rule before 1492), mauro meant negro and corresponded to Castillian usage in which moro was applied to horses whose color was negro. The corresponding more (French), maurus (Hispanic Latin), and moro (Valencian) were derived from Latin morus (negro) and ultimately from a Greek word meaning oscuro. Similarly, Mozarabic mauro was related to moro (Spanish and Italian), mouro (Portuguese and Gallego), mor (Provençal), maure and more (French), meaning 'Moro; negro; hombre de color'. These forms stem from Latin maurus (also from Greek), 'for the dark (oscuro) color of the Mauritanos o' Moros (peoples of northwest Africa)' (author's italics) (1993, p. 67). 
From Forbes' linguistic analysis it is clear that Europeans saw these invaders

coming out of North Africa mainly as "dark-skinned" Africans. The variant term "Tawny Moor," which denotes a Moor of a lighter or "white" complexion, merely underscores the centrality of color in its etymology. The following passage from Fletcher puts into perspective the size and scope of the Moorish invasion in all its hues:

The most authoritative estimate puts the number of Arab and Berber warriors who settled in Spain in the wake of the conquest as between 150,000 and 200,000. If they were accompanied, or later joined, by their wives, children, clients and slaves we should have to multiply that figure by perhaps four or five or six to arrive at an idea of the total number of immigrants to eight-century Spain. If on the other hand these were unattached warriors who acquired women and slaves for themselves in Spain, then the ethnic significance of the invasions will have been less marked. Common sense would suggest that both processes - single and group migrationoccurred. If the immigrants approached one million persons in the course of the eight-century this would represent a substantial shift in the ethnicity of the peninsular population. How substantial is a question that cannot confidently be answered since our information about the demography of late antique and early medieval Spain is almost non-existent (1992, pp. 25-26).

Fletcher estimates the population of the Iberian Peninsula in the late Roman period to be approximately four million, and argues that it did not grow significantly under the harsh rule of the Visigoths, who had seized the territory from the Vandals nearly three hundred years earlier and then fought among themselves over its control (1992, p. 26). Given the human resources involved, and the Arab practice of enlisting entire armies of Berber converts into their ranks, it seems reasonable to assume that the vast majority of immigrants to Spain in the eight-century came from North Africa and not the Arabian Peninsula. The Arab conquest of North Africa was among the bloodiest and most fiercely fought struggles to expand the borders of Islam. Fletcher notes:

They were nominally subjected by the early years of the eight-century, but continued to mount sporadic rebellions against Arab rule until the 740s and 750s. One way of taming the Berbers, and of simultaneously profiting from their 
fighting skills, was to encourage or compel their enlistment into Arab-led armies for the prosecution of military campaigns elsewhere (1992, p. 20).

The Berber warriors who eventually came to comprise the Arab armies in North Africa were recent converts from Christianity not acculturated to Arab ways or fluent in Arabic. The tribal confederacies, clans and families that both divided and loosely united the Berber peoples chafed under Arab authority, and from their continued treatment as second-class citizens in the expanding Muslim empire despite their conversion to Islam. Under these circumstances, unrest and revolts were common (Fletcher, 1992, p. 27). Pan African scholars also have investigated and documented the Berber roots of Moorish and Andalusian culture. James Brunson and Runoko Rashidi provide this useful background information:

Among the most substantial Berber groups to occupy Spain were the Hawwara, Luwata, Nafza, Masmuda, Miknasa, Zanata, and Sanhadja. Before participating in the eight century invasion of Spain, the Hawwara Berbers in Africa occupied the province of Tripolitania and the deserts of southern Tunisia. They worshipped the Libyan sun-god Amun, who was depicted as a bull or ram. After the invasion of Spain, they settled in Cordoba, and established a fortified city near Jaen. A wealthy group of Hawwara also settled in Morida and Medellin (1992, p. 57).

According to Brunson and Rashidi, Tarik ibn Ziyad, who led the invasion of Spain in 711, and Abd al-Rahman I, who founded the Umayyad dynasty in Cordoba, were both said to be Nafza Berbers. The Nafza supplied 40,000 troops that supported alRahman's usurpation of power in Iberia in 756 (Brunson \& Rashidi, 1992, p. 57). It is from the Sanhadja Berbers, also know as the Mulaththamun or "people of the veil," that the Almoravid sect arose in 1095, and created an empire that "lasted a hundred years and stretched from the Senegal River in West Africa to the Ebro River in northern Spain" (Brunson \& Rashidi, 1992, p. 61). This puritanical sect of Islam eventually was overrun by an even more fundamentalist group know as the Almohades, whose guiding principle 
was the unity of God. Rising up out of southern Morocco, these zealous sectarians ended Almoravid rule in the remaining territory of Andalusia in 1173 (Fletcher, 1992, p. 122). The Almoravid and Almohad dynasties represent the last two major migrations of troops and people from North Africa into Andalusia.

Although the controversy over the origin and identity of the founders of Andalusian culture persists, artistic and literary sources in Europe also offer important avenues for examining this question. Brunson and Runoko, following in the footsteps of J. A. Rogers, a pioneer in photo-journalism and photo-anthropology, feature several photographs in their essay of notable paintings, drawings and designs that depict the Moors as a diverse but phenotypically African group (1992). Brunson and Rashidi also cite Arab chroniclers from the era who refer to the invading troops as "Sudanese," which means, "black" in Arabic (1992, p. 55). Equally important, they note similar statements from primary Christian sources such as the Primera Cronica General of Alfonso X, which includes this graphic description of the Moors: "Their faces were as black as pitch, the handsomest among them was as black as a cooking pot (Brunson \& Rashidi, 1992, p. 55). 


\section{RACIAL DISCOURSE AND DISCORD IN IBERIA}

The turmoil surrounding the Arab conquest of North Africa and the ethnic and sectarian divisions that emerged after the conversion of the Berbers to Islam suggests the invasion and occupation of Spain contained within it the seeds of later discord and division. The Moors' opponents, the Visigothic rulers of Iberia—descendants of Germanic tribes who sacked Rome in 410 and dismantled what remained of the Roman empire—-seized the Roman province known as Hispania from the Vandals, an earlier Germanic tribe of invaders, and inaugurated three centuries of repressive rule over the local Romanized inhabitants. Menocal (2002), Fletcher (1992) and others paint a picture of Visigothic Hispania in the eight-century that depicts a culture rife with conflicts and contradictions. Although the Visigoths were "Christianized," they did not accept the orthodox doctrine of the Roman Catholic Church until 589 (Menocal, 2002, p. 24). In Hispania (the name by which the Iberian Roman province was then known), paganism or cosmotheism remained widespread among the rural masses despite the introduction and gradual spread of Christianity in the region. Jews, who had arrived with the Romans in the second century B.C.E., found themselves living in "nearly enslaved squalor" under Visigothic rule (Menocal, 2002, p. 25). Fletcher contends that what little is known about Hispania's Jewish community comes mainly from the many laws the Visigoths enacted against them, and states: "These edicts make ugly reading, especially to a twentieth- 
century mind and to historians who cannot but be aware of later outbursts of antiSemitism in medieval and modern Spain" (1992, p. 24). According to Fletcher, this antiJewish sentiment came from attitudes and practices originating in the eastern Roman or Byzantine empire that were apishly adopted by the Visigoths in Hispania, the Lombard kings of Italy, and the Frankish kings of Gaul (1992, p. 24). With Jews daily confronted by persecution, and the rural peasants of the peninsula struggling to survive under the oppressive taxes of their overlords, it is not unlikely that these aggrieved groups viewed the Moorish invaders more as liberators than conquerors. What is certain is that the invasion and conquest of Hispania proceeded rapidly, with the Muslim forces seizing control of the peninsula after a series of battles that decimated their opponent's forces in just three years.

In distributing land and plunder among the victorious Muslim soldiers, the Arab minority who controlled the reins of military power openly discriminated against the newly converted Moors (Berbers) who comprised the majority of Muslim forces. Fletcher asserts:

... the Arab minority among the conquerors got the most fertile lands, while the Berber majority were palmed off with the less favoured lands in the centre and north of the peninsula or in the more mountainous regions of the east and south. This inequality of distribution was to have serious consequences (1992, p. 25).

Thus within the first years of Muslim rule, the new polity of al-Andalus set forth policies and practices of discrimination based on ethnicity. Despite Islam's claims of universality, and Muhammad's exhortations to his followers to treat all Muslims equally, Arab chauvinism perpetuated and preserved social distinctions based on ethnic origins. Arab identity required both fluency in Arabic and the ability to trace one's ancestry back to the marauding Arab tribes who founded the growing Islamic empire. Few of the 
Moorish converts who made the conquest of Hispania possible could claim Arab ethnicity and few, initially, were fluent or literate in Arabic. Along with a pronounced attitude of religious superiority, Arabs also conveyed and expressed their color prejudice against "black" or "dark-skinned" peoples through various social policies and practices.

Brunson and Rashidi offer the following illustrative comments on this point:

With the conquest and settlement of Spain, the Arabs developed patterns of racial bias towards the Berbers. This bias, sometimes blatant and other times more subtle, manifested itself in various ways, including disproportionate tax assessments and poor land allotments. For example, after founding the Almohad dynasty, the Berber ruler Abd al-Mu'min offered the Granadan post of "able secretary" to an Arab poet named Abu Ga'far. Scheduled to work with asMu'min's son, Abu Said, the Arab poet hesitated "because the dark-skinned Berber seemed to him far below his own intellectual standards (1992, pp. 55-56).

The above incident, minor as it may seem, followed a pattern throughout the Islamic world based on beliefs in "black" debasement stemming from Noah's curse of Ham—as commonly interpreted by the three western monotheisms (Judaism, Christianity and Islam)—and by the massive increase in the Islamic trade in "black" slaves subsequent to the Muslim conquest of North Africa. Although the Noachic distinction is grounded in religious beliefs and texts, it also influenced the development of western ethnological discourse on "black" Africans. Several examples of Muslim treatises on this subject (al-Tabari, etc) have been previously cited, but similarly proto-racist statements can be found in the works of Jewish and Christian scholars of the same era, a number of whom were educated in the intellectual centers of Moorish Spain. The notable Andalusian writer, Benjamin of Tudela, offers an interesting case in point. A Jew from Navarre in the north of the Iberian Peninsula, Benjamin chronicled his travels in Europe, Asia and Africa between 1169 and 1171 in a diary known as The Itinerary. Writing in 
Arabic, his first language, Benjamin described the places and people he visited. On a journey in the region south of Egypt, he made the following observation:

There is a people among them who, like animals, eat of the herbs that grow on the banks of the Nile and in the fields. They go about naked and have not the intelligence of ordinary men. They cohabit with their sisters and any one they can find. When the men of Assuan make a raid into their land, they take with them bread and wheat, dry grapes and figs, and throw the food to these people, who run after it. Thus they bring many of them back prisoners, and sell them in the land of Egypt and in surrounding countries. And these are the black slaves, the sons of Ham (cited in Sweet, 1997, pp. 151-152).

In this brief passage, Benjamin provides a glimpse into several literary genrestravel writing, ethnography, and biblical exegesis—and how they were combined in a manner that was common among scholars of his era. What is equally noteworthy is his claim that the people he observed were "like animals" in their nakedness, lack of intelligence, eating habits, and credulity. His invocation of Noah's curse shows its continuing and evolving use as a justification for "black" slavery in the Middle Ages. Several centuries before Benjamin's text appeared, the Tanhuma, an eight-century Midrash offered this explanation for Ham's predicament:

As for Ham, because he saw with his eyes the nakedness of his father, his eyes became red; and because he spoke with his mouth, his lips became crooked and because he turned his face the hair of his head and his beard became singed and because he did not cover his father's nakedness, he went naked and his prepuce became stretched, [all this] because all of God's retributions are commensurate to a transgression (cited in Sweet, 1997, p. 148).

Without explicitly mentioning "black" people or slavery, this attempt to explain Noah' curse, tit for tat, seems to point directly to the constellation of stereotypes associated with Africans: big lips, big penises and kinky hair. This set of "racial" symbols and their associated myths found common and receptive ground in Andalusia in Jewish, Muslim and Christian communities. Dark skins, no doubt, offered a sharp contrast to the 
"light-skinned" inhabitants of Iberia and the so-called tawny complexions of many Muslims. Consequently, as Sweet notes: "The invidious perception of difference, expressed in language that suggested black inferiority, became refined and sharpened by Muslims, Jews, and Christians of Iberian origin" (1997, p. 149). Iberians of all backgrounds became conscious of the association of "blackness" with slavery through the introduction of the Muslim system of slavery into Andalusia. The "black" Africans who formed a significant group within the slave population of this regime were vilified by each monotheist party for being pagans, but in the hearts and minds of Iberian Christians "blacks" were "doubly cursed" (to use Sweet's expression) because "they were the Muslim's servants, the heathen's heathen ..." (Sweet, 1997, p. 149). The mutual hostility of Christians and Moors, the fact that they regarded each other as infidels, did not preclude, however, their finding common ground in their vilification and exploitation of "blacks." In fact, they both viewed the Almoravid, the sub-Saharan Muslim sect who wrested control of North Africa and Andalusia from the Almohades in 1095, as "savages" and "barbarians" (Sweet, 1997, p. 153). The Cantigas de Santa Maria, a collection of poems celebrating the virtues of the Virgin Mary, which the king of Castile, Alfonso X (d. 1284), claimed to have composed, contains in its 427 verses numerous examples of negative images of "blacks." Most noteworthy for this discussion is the distinction Alfonso makes between "white" and "black" Muslims. According to Sweet, cantiga 385 describes an upcoming battle between Spaniards and Muslims as warfare against two enemies: "the Moors of Spain and the Africans" (1997, p. 153). It is possible Alfonso makes such a distinction because he viewed the "Moors" as fellow residents in Iberia (after their several centuries there) and the Almoravids as recent invaders and interlopers 
in the affairs of the peninsula. But the general antipathy towards "blacks" in the cantigas seems to belie this point. Again, Sweet finds:

While it should be stressed that Muslims and Jews generally are treated with scorn throughout the cantigas, the persons with the darkest skins are consistently portrayed as posing the gravest danger to Christian purity and receive more sever punishments than those meted out to other infidels. If these representations do not signify racism, they manifest a well-entrenched Christian aversion to blackness (1997, p. 154).

Here, Sweet refers obliquely to the Manichaean iconographic conventions in Christian art that portray demons as black and suggests these notions found their parallel tropology in ethnographic and literary descriptions of African peoples. It is also important to reiterate the role of slavery and the slave trade in fostering these negative racial images. Slavery was widespread in the Iberian Peninsula. Fletcher points out: "Medieval Spain remained a slave-owning society at a time when slavery was gradually disappearing in western Christendom. And this was not just in the frontier areas" (1992, p. 136). Muslims enslaved Christian prisoners-of-war and Christians avidly employed a similar policy. For example, Christians used enslaved Muslims to build the cathedral of Santiago de Compostela in the twelfth century, while Christian slaves helped to construct the Kutubiyya mosque in Marrakesh. The Aragonese conquerors of the island of Minorca in 1287 sold the entire Muslim population into slavery, with the exception of the wealthy elite who paid a ransom so they could immigrate to North Africa (Fletcher, 1992, p. 136). Latin texts of the era demonstrate that Christians adopted the Muslim practice of and terminology for distinguishing light-skinned from dark-skinned slaves. "Black" slaves were called maurus, and "white" Muslim slaves were called sarracenus (Sweet, 1997, p. 150). From as early as 1332 , documents relating to the sale of slaves show Christians differentiating "white" from "black" slaves in this customary manner. These "racial" 
markers comprised only a part of the lexicon of difference that came to typify the ethnic and religious categories used to classify Iberia's diverse populations in the medieval era. In addition to Moors, Jews, Christians, Arabs, Visigoths, certain important subdistinctions developed indicative of the social dynamics that prevented the Iberian melting pot from reducing its constituents to a harmonious Andalusian homogeneity. Despite the obligation for the faithful to emigrate from lands taken by infidels, Muslims remained in provinces "reconquered" by Christian armies, and many Christian remained in Moorish-ruled territories. Fletcher furnishes this succinct description of two classes of Iberians (Mudejar and Mozarab) that developed from these circumstances:

A person who elected to stay was known in the Romance vernacular as a mudejar, a word derived from the Arabic al-mudajjar, rendered in the thirteenth-century glossary of Ramon Marti as 'persons allowed to remain'. Among historians of today the word Mudejar is widely used (both as noun and as adjective) to label the culture of the Muslims who lived under Christian rule in medieval Spain — just as the term Mozarab is used of the Christians who lived under Muslim rule (1992, p. 137).

Other common designations of the era-Muladi (a Christian who converted to Islam); converso (a Jew who converted to Christianity); Marrano (a Jew who converted but remained a secret Jew); and Morisco (a Muslim who converted to Christianityreveal how religious identity was scrutinized, codified and obsessively guarded. Group identity as determined by religious affiliation constituted the most significant indicator of status in this hostile and fractious society. Special laws and edicts restricted and governed the activities of these groups within their respective polities. Mudejars enjoyed freedom to worship under Christian rule but were enjoined from proselytizing and were required to pay certain taxes. Under Muslim authority, Mozarabs also were permitted religious freedom subject to the same or similar restrictions. Sexual relations across the religious 
and cultural divisions, however, were prohibited and punishable by death. Muslims publicly executed offenders by stoning. Through compulsion or by choice Mudejar and Mozarabs often lived in ghettoes within their respective polities. Under such circumstances, discrimination occurred frequently and often without any form or mechanism for redress. Fletcher uses the term "apartheid" to describe legislation of the era, which, among other prohibitions, segregated or restricted the use of municipal bath houses to specific days for Muslims, Jews and Christians, prevented them from hiring each other for certain employment (such as nannies), and even forbade them from wearing certain clothing styles or colors (1992, p. 138). Religion, of course, constituted the basis for these social and legal restrictions. The Mosaic distinction and its believer/non-believer dichotomy thus furnished the template from which an apartheid system (separate and unequal) developed to police and enforce religious and related cultural differences. It does not take a leap of faith or even a short walk along this path to see how "ethnic" traits or characteristics associated with these groups became incorporated in the theological and ideological construction of difference in Andalusian culture. The cognitive journey from religious antipathy to ethnic stereotypes to racial stereotypes to racism needed but a few conceptual missteps-fueled by ethnic chauvinism (Eurocentrism), acquisitiveness (capitalism), and the Will to Power cited by Dussel (Dussel, 1993, 2000) in his analysis of Eurocentrism and modernity. Iberia performed a decisive geo-social role in facilitating the cognitive steps or missteps of that journey. The story of Moorish Spain must be understood not only as a chronicle of Muslim conquest and colonization in Europe, but as the expansion of Christian power and authority during the "reconquest" of Iberia by the monarchies of Aragon, Castile and 
Portugal. Through this conflict, in which Christians emerged as the dominant power in the peninsula from the twelfth century onwards, the Manichaean impulses within western monotheism, with its binary structure and color-coding, furnished the allegorical mechanism whereby ethnicity (especially, "blackness") became an overt "sign" or "signifier" of difference. The final "blackening" of the "other" in European consciousness occurred when the term "negro" became synonymous with "slave." This process had already taken place or was well under way within Islamic society. While Christians, Muslims and Jews held beliefs and doctrinal views that were in sharp contrast or contention, they could and did agree and cooperate in the debasement and exploitation of "blacks." James H. Sweet expresses this same point thusly: "Though Christians and Muslims regarded one another as infidels, adherents of both faiths found common ground in their disparagement of black Africans. The rhetoric of black African subhumanity reflected a set of shared understandings by Christians and Muslims on the Iberian peninsula" (1997, p. 152).

That Andalusia comprised a melting pot of sorts where pagans, Jews, Christians and Moors intermixed and intermarried cannot be disputed. However, the seemingly intractable role of skin color as a factor in its social stratification was no more mitigated by "miscegenation" than in America's slaveocracy when Thomas Jefferson or other members of the ruling plantation aristocracy produced "half-breeds" with their slavemistresses. The result, of course, was more mulattoes or mixed persons, but that fact in itself generally strengthened the existing color line and its social regulation and enforcement. 


\section{MOORISH SPARK, EUROPEAN RENAISSANCE}

Spanish historians have coined and used the term convivencia ("living together") to describe the social experimentation conducted by Muslim and Christian authorities that sustained the multi-cultural societies that existed in Iberia in the Middle Ages when the peninsula was a checkerboard of various Christian and Muslim principalities. The term implies a certain amount of cooperation and even harmony that is belied by the fundamental and deep social and doctrinal divisions that separated Jews, Christians and Muslims. The sub-title of Menocal's book refers to "How Muslims, Jews, and Christians Created a Culture of Tolerance in Medieval Spain” (italics added) (2002). Tolerance, according to the Random House Dictionary, denotes "a fair, objective, and permissible attitude toward those whose opinions, practices, race, religion, nationality, etc., differ from one's own ..." (Flexner, 1987). The attitudes, practices and polices prevalent in medieval Spain described thus far fall far short of the "culture of tolerance" suggested by Menocal's sub-title. Moreover, despite the possibility of some confusion on this point, tolerance does not connote or imply acceptance. Underlying the concept of "culture" is the notion that it consists of commonly "accepted" and agreed upon normative beliefs and behaviors. What Menocal really seems to be referring to is the pragmatic and expedient manner in which Jews, Muslims and Christians grudgingly cooperated with each other to advance their own cultural causes and not necessarily a common cultural 
cause or good. Charles J. Halperin, in his essay titled, The Ideology of Silence: Prejudice and Pragmatism on the Medieval Frontier contends:

The demands of religious prejudice prevented the formulation or articulation of any medieval theories genuinely equivalent to modern concepts of peaceful coexistence or detent. One might admire, intermarry with, trade with, even borrow intellectual skills from the infidel, but never concede the legitimacy of his religion. To admit the legitimacy of the religion of the enemy would have automatically called into question the insistence upon the exclusive religious superiority of one's own. Since religion subsumed under it one's conception of the political and social order-one's way of life—-such ideological tolerance would have undermined the social, political, and cultural foundations of one's own society and polity. For this reason, exchange at the intellectual level, inextricably tied to religion, became even more difficult to achieve (1984, pp. 465-466).

In Halperin's view, the crusader kingdom of Valencia, a territory "reconquered"

from the Moors in the thirteenth century, exemplifies the inevitable results of the culture of intolerance that prevailed in Moorish Spain. After the Christian takeover of Valencia, Catholics comprised less than fifteen percent of the population. Efforts by Catholic missionaries to convert the bulk of Valencia's Muslim population to Christianity, coupled with legal and commercial assaults on the status and property of the Muslim aristocracy, led to a series of bloody revolts and the mass exodus of the wealthy Moorish elite for Moorish lands. The Mudejar, the Muslim peasants who remained behind under Christian rule, continued their precarious existence as an oppressed minority. Thus, Halperin concludes: "Ultimately hatred outran and overwhelmed cooperation in Spain, or, to put it another way, prejudice outweighed pragmatism" (1984, p. 447).

The intellectual and artistic achievements that emerged from the three-way rapprochement between Christians, Muslims and Jews have fostered popular notions of benignancy and harmony in medieval Spain's quest for social progress and enlightenment. This efflorescence of philosophical, scientific and technological 
knowledge and skills in al-Andalus, when the rest of Europe languished in the doldrums of the dark ages, has resulted in the tendency to idealize and romanticize Andalusian culture. Menocal celebrates this supposed spirit of pre-modern ecumenicalism and refers to Andalusian culture as "first rate [in its] ability to hold two opposed ideas in the mind at the same time" (2002, p. 10). For Menocal, tolerance means these hostile religious groups were able to find, through a process of "unconscious acceptance," some "positive" or "productive" mechanism for dealing with internal and external contradictions to their belief systems and behaviors (2002, p. 11). But such "positive" outcomes, as Menocal describes them, again point to a kind of pragmatism based on "self" rather than "mutual" interest. Here is how Menocal iterates the function and products of this Andalusian "culture of tolerance:"

It was there that the profoundly Arabized Jews rediscovered and reinvented Hebrew; there that Christians embraced nearly every aspect of Arabic style-from the intellectual style of philosophy to the architectural styles of mosques-not only while living in Islamic dominions but especially after wresting political control from them; there that men of unshakable faith, like Abelard and Maimonides and Averroes, saw no contradiction in pursuing the truth, whether philosophical or scientific or religious, across confessional lines. This vision of a culture of tolerance recognized that the incongruity in the shaping of individuals as well as their cultures was enriching and productive. It was an approach to life and its artistic and intellectual and even religious pursuits that was contested by many - as it is today — and violently so at times — as it is today-and yet powerful and shaping nevertheless, for hundreds of years (2002, pp. 11-12).

As we have seen, Maimonides' pursuit of "the truth" led to his conclusion that genocide was an acceptable means to prevent the spread of false doctrines advocated by Muslims and the descendants of Ham. Maimonides and other Iberian intellectual luminaries of his era indeed may have pursued and found truth "across confessional lines," as Menocal claims, but they validated such truths within the strictures and dogma of their own religious ideologies. 
That incredible advancements in education and the arts and sciences occurred in Moorish Spain is not in dispute, nor is the notion that a "culture of enlightenment" flourished there for centuries. But one could equally propose that conflict and competition rather than "tolerance" promoted its evolution and development. Instead of "How the Muslims, Jews and Christians Created a Culture of Tolerance in Medieval Spain," it could be argued that we are seeing in the efflorescence of Andalusian knowledge and culture: "how the Muslims, Jews and Christians initiated an intellectual revolution through competition, conflict and constant warfare." The modern Cold War, which was fueled by a similar ideological divide—albeit one rooted in economics and the conflict between religion and atheism—also led to incredible advances in knowledge, particularly military and space technology.

The culture of scholarship that made the "Golden Age" of Andalusian civilization possible was founded and grounded in Arabic, the "lingua franca" of intellectuals in the medieval era, and disseminated through the libraries and universities of Andalusia, which were regarded by many as the greatest institutions of learning in the medieval world (Pimienta-Bey, 1992). With the Arab conquest of Egypt and Iraq, Arabs rediscovered the vast repositories of ancient texts from North Africa and the Near East, and, with the aid of the conquered, set about the task of translating them into Arabic for study and dissemination. With the valuable literary resources of these ancient centers of learning, and new networks of scholarship initiated through Arab contacts in India and China, the Moors and Arabs devised and presided over a global think tank that revitalized and transformed education in the medieval world. Afrocentric historian John G. Jackson 
vividly contrasts the intellectual lights of Moorish Spain with the stark illiteracy of other

European countries in the late middle ages:

Education was universal in Moslem Spain, being given to the most humble; while in Christian Europe, 99 percent of the population was illiterate, and even kings could neither read nor write. In the tenth and eleventh centuries, public libraries in Christian Europe were conspicuous by their absence, while Moslem Spain could boast more than seventy. One library in Cordoba housed 600,000 manuscripts. Christian Europe contained only two universities of any consequence, while in Spain there were seventeen outstanding universities. The finest were those located in Almeria, Cordoba, Granada, Jaen, Malaga, Seville, and Toledo. Scientific progress in astronomy, chemistry, physics, mathematics, geography, and philology in Moslem Spain reached a high level of development in Moorish Spain. Scholars, scientists, and artists formed learned societies and scientific congresses to promote research and facilitate the spread of knowledge (1990, p. $133)$.

Jan Carew, a founding figure in Pan African scholarship, has written extensively on the Moors and the role of Moorish arts and sciences in the rise of European imperial power. His work examines the scientific, technological, and literary legacy of Moorish culture and its influences on European artists and intellectuals as diverse as Cervantes, Dante, Defoe, Fielding, Shakespeare, Roger Bacon, and Lorca. He describes Moorish culture in Europe as having a "ripple-effect," a movement "in concentric rings from centers of learning to the most backward areas of the continent" (J. Carew, 1992, pp. 260262). The following passage illustrates how this "ripple-effect" took effect, as an endless parade of scholars from England, France, Germany, Italy, and distant parts of the Muslim empire came to Andalusia in search of enlightenment:

Many of the European scholars came to learn Arabic so they could read and popularize the knowledge acquired in Moorish centers of learning amongst their own relatively backward people. The Moorish city of Toledo, which was reconquered in 1085, became a cornucopia of newly discovered learning for a benighted population of Europe beyond the Pyrenees, and Christian rulers, from Alphonso VII (1126-1157) onward encouraged the establishment of schools of translation and of Arabic/Oriental studies in order to ensure a steady flow of new scholarship into their kingdoms (J. Carew, 1992, p. 258). 
Much of the educational activity in Andalusian culture not inspired by Islamic theology and exegetical discourses on the Quran was sparked by the translation and circulation of classical texts dating from the Greco-Roman era and earlier. Richard E. Rubenstein in a recent book, Aristotle's Children: How Christians, Muslims and Jews Rediscovered Ancient Wisdom and Illuminated the Dark Ages (2003) examines how the great translation centers in Toledo, Paris, Padua and Oxford produced and distributed classical texts and Arabic treatises and commentaries that both heightened the contradictions between religion and science (faith and reason) and established new means to reconcile those conflicts within the Christian Church and European culture. In his dissertation, however, Rubenstein adheres closely to the Eurocentric tradition of presenting Aristotle as a self-created, singular force in the invention of the "western" scientific tradition. Rubenstein's hagiographic treatment of Aristotle as the fount of ancient wisdom obscures the deeper African and Levantine roots of "Greek" science and philosophy as argued by W. E. B. Du Bois (1946) George G. M. James (1954), Cheikh Anta Diop (1955) Martin Bernal (1987), and others. This reification of all things Greek also is a common element in early and modern Islamic scholarship. Carew bluntly assesses this tradition as follows:

... some Arab/Islamic scholars, while deriding the narrow focus of the Eurocentric tunnel vision, and the implicit racism built into it against them, become racists themselves when dealing with Black Africans. In addition to the reprehensible role they played in the Slave Trade, they have developed a myopic and chauvinistic vision of their role in history and cling to Greek and Middle Eastern civilizations while ignoring the tremendous contributions that Africa made to Islamic civilization (1992, p. 252).

Carew's comments specifically confront the views of some modern Arab scholars, but the same point applies to their predecessors in Islamic Spain who failed or 
refused to credit the important African (Egyptian) sources that informed and inspired Greek learning. Rubenstein's comments on al-Kindi, who some regard as the ninth century founder of Muslim philosophy, illustrates this point:

Al-Kindi ... acknowledged his people's debt to the Greeks. Without them, he wrote, "it would have been impossible for us, despite all our zeal, during the whole of our lifetime, to assemble these principles of truth which form the basis of the final inferences of our research." He also described the Arab scholars' method, which was "first to record in complete quotations all that the Ancients have said on the subject, secondly to complete what the Ancients have not fully expressed, and this according to the usage of our Arabic language, the customs of our age, and our own ability." This bold attempt to "complete" the work of the Greeks permitted al-Kindi and his successors to adapt classical ideas to the requirements of contemporary Muslim civilization. For the next three centuries, the Arab philosophy movement (falsafah) generated works of great originality by thinkers like al-Farabi, the founder of Muslim Neoplatonism; the Jewish mystic, Ibn Gabriol (Avicebron to Latin-speakers); the brilliant Persian, Ibn Sina (Avicenna); Moses Maimonides of Cordoba, the Jewish sage; and his fellow Cordoban, the boldest of all commentators on Aristotle, Ibn Rushd (Averroes) (2003, p. 15).

The works of these scholars and others from the Islamic world could be found in the libraries of Andalusia along with the corpus of classical writings that influenced them. But the great libraries and universities of Andalusia, like the great European universities of Heidelberg and Oxford, also served as incubators in the development of the philosophy and ideology of antiblack racism and Eurocentrism. Along with learned treatises on astronomy, chemistry, physics and mathematics, these educational institutions translated, taught and disseminated the popular ethnographic studies and travelogues of prominent Muslim scholars that authorized and promoted the stereotypic depiction of "blacks" as sub-humans fit only for servitude. The rarefied intellectual and urbane culture of alAndalus, with its public baths, ornate architectural styles and "modern" urban design features, rested on a foundation of human slavery, a base that became increasingly "black" as supplies of "white" slaves diminished significantly during the late medieval 
era. And although a significant percentage of the Moorish population could be described as phenotypically "African," the presence of large numbers of free "blacks" in Andalusia did not seem to mitigate the negative racial imagery that permeated Iberian society.

Factors having to do with Arab ethnocentrism, patrilineal customs, and the "mulatto problem" encouraged or coerced those of mixed ancestry to cast their lot with those who imposed the caste system and its color-code. Those caught "in the middle" consciously or unconsciously helped to enact and institutionalize the two dominant principles of racist ideology as defined by Lewis Gordon and cited earlier: “(1) be white, but above all, (2) don't be black” (1997, p. 63). Gordon's “principle of white supremacy and principle of black inferiority" contributed decisively to the sociology of knowledge in Iberia that formed and informed the "Golden Age" of the Moors.

How Moors and other "blacks" in Iberia became complicit in their own denigration and "racial" debasement remains a subject ripe for further analysis and elucidation. In closing, however, it is important to address again the role of Islam in the formation of the white supremacy half of the racial ideology equation: Eurocentrism. The following comment by Menocal about the Visigothic role in the breakup of the Roman empire reflects the historicist ideology that informs the social construction of European identity and Eurocentrism: “The collapse of Rome's northern and eastern frontiers and the assumptions of power by various Germanic tribes ruptured Europe's connection with its own cultural past, an event that would shape the West's consciousness of itself" (2002, p. 25). The assumption and view that Greco-Roman civilization is "European" is integral to the modern conception of Europe and European identity. Greece and Rome, however, regarded Egypt and Mesopotamia as the centers of ancient knowledge and technology 
and viewed themselves as culturally connected to those southern regions across the Mediterranean. The Germanic "barbarians" who invaded and destroyed the Christianized Roman Empire from the north were more genuinely "European," in a geographic sense, than those they conquered. Vandals, Visigoths, Franks and Britons therefore better exemplified "Europe's own cultural past" than the Mediterranean societies who had assimilated the Egyptian-Babylonian-Judeo-Christian traditions and customs of Africa and the Near East.

The emergence of the powerful empire of Islamic faith after the death of the Prophet Muhammad erected a seemingly insurmountable ideological barrier for the first time in history between Mediterranean "Europe" and the "southern" lands across the Mediterranean. Beginning with the Moorish invasion and conquest of the Iberian Peninsula in the eighth century, and continuing until 1492 when the forces of Ferdinand and Isabella defeated Grenada (the last Moorish province in Andalusia or southern Spain), a technologically and intellectually underdeveloped Europe, under attack along the entire length of its southern borders, found itself in the paradoxical position of craving Muslim learning while crusading against Muslim religion. This conflict created the context and conditions for Europe's isolation and differentiation from the rest of the known world. Dussel argues that prior to the twelfth century Europeans did not see themselves as categorically distinct from the peoples of the eastern Mediterranean or North Africa. He refers to this change in the meaning of the concept of Europe as a “semantic slippage” (Dussel, 2000, p. 465). But more important, like Martin Bernal in Black Athena, Dussel traces the origins and lineage of the "unilateral diachrony Greece- 
Rome-Europe" to "late-eighteenth-century German romanticism" (2000, p. 465). Dussel states:

What became modern Europe lay beyond Greece's horizon and therefore could not in any way coincide with the originary Greece. Modern Europe, situated to the north and west of Greece, was simply considered the uncivilized, the nonpolitical, the nonhuman... Therefore, the single line of development Greece-Rome-Europe is a conceptual by-product of the Eurocentric "Aryan model" (Dussel, 2000, pp. 465-466).

Dussel also makes the salient point that Latin Europe of the Middle Ages viewed Aristotle as belonging to the Arab rather than Christian world. Aristotle's writings on metaphysics and logic did not arrive in Paris until the end of the twelfth century, and did so bearing a distinctly Muslim imprint after having been studied by Arab scholars in North Africa and the Near East for several centuries. European scholars like Abelard, Albertus Magnus and Thomas Aquinas, who espoused and drew heavily upon Aristotelian philosophy, did so at the risk of condemnation and even execution by the Latin Church (Dussel, 1993, 2000). Stretching as it did from the Atlantic to the Indian Ocean and into the Pacific, the Islamic empire, from the European perspective, seemed to encompass most of the known world. This geographic fact based in an ideological reality forced Europe for the first time in its history to differentiate its Latin, Christian, western world from the vastly larger and more sophisticated Muslim world. The fall of Constantinople in 1453 in the midst of the Italian Renaissance helped to spark a new geosocial consciousness by uniting the eastern Greek (Byzantine) and western Latin worlds in confronting the Turkish-Muslim world. This strategic realignment of political and religious interests, according to Dussel, "thus allowed to emerge the false equation Western $=$ Hellenistic + Roman + Christian. "In such a fashion," Dussel argues, "the Eurocentric ideology of German romanticism ... was born" (2000, pp. 467-468). 
The European imperial expansion in the fifteenth-century that followed in the wake of the fall of Moorish Granada in Spain drastically redefined, through the exercise of raw power, the nature of prior global and cross-cultural relationships. Thus, according to Dussel, imperialism and colonialism fostered "the ideological invention that first kidnapped Greek culture as exclusively western and European and then posited both the Greek and Roman cultures as the center of world history" (Dussel, 2000, p. 468). Colonizing the past to control the present and reinvent the future, imperial Europe proclaimed itself the genealogical descendant of Greco-Roman culture and projected its imagined ancient lineage and centrality backwards in time to encompass all human history and development. The local "histories" of North Africa and Asia were subsumed or became peripheral appendages to modern monolithic Europe under a type of historicism that re-inscribed, erased or conveniently forgot the past. Besieged by the Islamic world from the eight to the fifteenth century, Europe, then, was not the "center" of anything (except, perhaps, resistance to Islam). As Dussel bluntly states, "[it] amounted to nothing more than a peripheral secondary geographical area situated in the westernmost limit of the Euro-Afro-Asian continent" (2000, p. 468).

The claims of Menocal and others notwithstanding, Europe did not reclaim through the corpus of classical writings introduced by the Moors an ancient heritage that was its own, instead it established a modern identity based on its claims to an antiquity that was in its roots African and Asian, and in its modes and methods of transmission, Islamic. It merged Judeo-Christian ideology with classical Hellenism under the auspices of Islam to forge a new identity, a new ego and self, and reinvented geographical Europe as a polity and cultural ethos using technology and ideology borne out of religious conflicts and 
warfare. The Moors and Arabs transformed Iberia, the westernmost region of Europe, from a remote and sleepy backwater under Visigothic rule to a vibrant center of Islamic faith, power and prestige. The Reconquest of the peninsula by Christian forces transformed it from an urbane outpost of Islamic civilization to the birthplace of the trans-Atlantic slave trade, the Inquisition, Eurocentrism, colonialism, and antiblack racism. 


\section{CONCLUSION: THE AGE OF DISCOVERY, GENOCIDE, SLAVERY, RACISM}

The dramatic surrender of Grenada, the last Moorish province in Spain, to the conquering forces of Ferdinand and Isabelle on January 2, 1492, was followed eight months later on October 12, 1492 by an initially unheralded event on an obscure island in the Caribbean Sea. When Christopher Columbus and his motley crew staggered up the beach on Guanahani, a tiny island in the Bahamas, blissfully ignorant of their whereabouts, they were greeted by a group of curious "Arawakian Lucayos," who were blissfully unaware they would be the last of their kind and the first among millions of victims of Spanish colonial conquest and imperial expansion (J. Carew, 1994, p. 3). Had they been the benighted savages they were later portrayed to be by Columbus and the host of conquistadors that followed his ship's wake across the Atlantic, they would have fallen on the foreigners and slain them to a man, thus preventing or at least delaying a horrific fate. Instead they probably watched in bemused silence as Columbus and his crew unfurled the flag of Isabella of Castile and Ferdinand of Aragon and loudly proclaimed the lands and its inhabitants to be the possessions of Spain.

The European "voyages of discovery," the "ceremonies of possession" enacted on countless "American" shores, and the enslavement, colonization and genocidal decimation of the Caribbean peoples that followed in their wake were the opening performances of European colonialism in the so-called New World, a system of conquest 
and exploitation that had had its dress rehearsal in the Reconquista of Andalusia and in the establishment of the slave trade along Africa's western coastline. Jan Carew, in Rape of Paradise: Columbus and the birth of racism in the Americas, argues the Spanish brought the long-term effects of religious warfare and centuries of hostility against the Moors and Jews with them to the New World where it "spilled over" and ignited a holocaust that decimated native peoples. Yet it was Moorish and Jewish thinkers and scientists who made Europe's great leap backwards into the New World possible. Carew states:

In spite of the militant rejection of everything Moorish by the victorious Spanish rulers after the fall of Granada, it is ironical that Columbus' First Voyage across the Ocean Sea would not have been possible without the great advances in navigation, mathematics, geography and astronomy that the Moors had brought to the Iberian Peninsula. Columbus had spent a number of years in Portugal before moving to Spain. And it was during those years in Portugal, where the heritage of Moorish enlightenment had made that small country a great center for nautical sciences, that he mastered the crucial theoretical basics of navigation (1994, p. 39).

The "ripple-effect" of Moorish scholarship_-what Carew describes as the movement of Moorish knowledge "in concentric rings from centers of learning to the most backward areas of the continent"- also conveyed the impulses and imperatives of racial discord and racial discourse (J. Carew, 1992, pp. 260-261). The educational philosophy disseminated and acquired during this era of enlightenment included an ideology of hate and its associated apparatus. The ideology of hate produced the edict signed by Isabella of Spain on March 31, 1492 ordering the expulsion of Jews from Spain. Her appointment of the infamous Tomas de Torquemada to head the Spanish Inquisition put in place the institutional apparatus needed to police and enforce Spain's Christian identity with a brutal inefficiency. Property confiscated from the 
disenfranchised Moors and Jews under the authority of Isabella's edict was used to

finance Columbus' first voyage. Moreover, as Carew argues:

“... ethnocide would become an intrinsic part of Spanish domestic and overseas policy. And this nefarious edict would also become the prelude to the extermination of the Guanches of the Canary Islands (Spain's first overseas territory), and the Tainos, Caribs and other Native Americans of the New World. This Spanish precedent established an ethnocidal tradition that was soon adopted by all of the European colonizers who came in their wake (1994, p. 49).

In addition to heretics and infidels, the apparatchiks of the Holy Inquisition consigned to the flames thousands of books from the great Moorish libraries, volumes that comprised "the cream of Islamic and Hellenistic learning which had been fed from its earliest beginnings by African roots buried deep in the creative soil of that much maligned and deliberately misunderstood continent" (J. Carew, 1994, p. 49). Supremely ignorant of the loss of these great intellectual treasures, the agents of the Inquisition sent the combined and collective heritages of the ancient and medieval worlds billowing upwards in clouds of smoke and soot. The result of this literary conflagration was twofold: knowledge that threatened the hegemony of the Holy Bible and the Catholic Church could be eliminated at the source, and the traces of non-European influences on Europe's development and socialization could be erased or effaced. Thus the great European thinkers who emerged during the height of the imperial era in the so-called age of European Enlightenment could declare that Europe invented itself by itself. By sheer sophistry and intellectual sleight-of-hand European scholars like Hegel, Hume and Kant proclaimed Europe free of all external influences. Others Europeanized the Greco-Roman and Judeo-Christian traditions and used them to establish and articulate the Eurocentric discourse that claimed European culture was founded on rational principles and grounded in the "historical" reality of its centrality in human development. Martin Bernal's Black 
Athena furnishes an excellent summary of the genealogy of Aryan discourse and the particular historicist "model" it created to mythologize and reify the origins of modern Europe. Bernal shows how European scholars systematically erased the "Oriental" roots of European religious and intellectual traditions and substituted what J. M. Blaut refers to as the "European Miracle"- the idea that Europe forged ahead of the rest of the world in its prehistory and thus dominated the history of the globe (Bernal, 1987; Blaut, 1993). Once this idea achieved it cogency and currency non-European cultures and civilizations were reduced to the dust-heaps of history. Bernal states: "Indeed, since the $19^{\text {th }}$ century it has become literally unthinkable to Europeans that peoples of any other continent could be "scientific" in the way they themselves are, or that Asians or Africans could have contributed in any profound way to the making of Europe" (1987, p. 236).

The Spanish Inquisition's burning of Arabic texts also set a precedent for book burning as a means of erasing the past of indigenous cultures in the Americas. In the midsixteenth century Diego de Landa, the first Bishop of the Yucatan, destroyed the corpus of Mayan literature in an act of utter ignorance and bigotry. De Landa placidly describes and justifies his actions as follows:

These people used certain characters or letters, with which they wrote in their books about their antiquities and their sciences; with these, and with figures, and certain signs in the figures, they understood their matters, made them known, and taught them. We found a great number of books in these letters, and since they contained nothing but superstitions and falsehoods of the devil we burned them all, which they took most grievously, and which gave them great pain (quoted in (cited in Mignolo, 1995, p. 71).

Perhaps the most effective means for the erasure of the local cultures and histories of the diverse populations that inhabited the Americas, and their supplanting with European culture and history, occurred through the routine implementation and operation 
of European colonial policies and practices. Ward Churchill offers this harrowing

overview of the European impact on Native Americans:

During the four centuries spanning the time between 1492, when Christopher Columbus first set foot on the "New World" of a Caribbean beach, and 1892, when the U.S. Census Bureau concluded that there were fewer than a quartermillion indigenous people surviving within the country's claimed boundaries, a hemispheric population estimated to have been as great as 125 million was reduced by something over 90 percent. The people had died in their millions of being hacked apart with axes and swords, burned alive and trampled under horses, hunted as game and fed to dogs, shot, beaten, stabbed, scalped for bounty, hanged on meathooks and thrown over the sides of ships at sea, worked to death as slave laborers, intentionally starved and frozen to death during a multitude of forced marches and internments, and, in an unknown number of instances, deliberately infected with epidemic diseases (1997, p. 1).

These Native Americans also were the first unfortunate victims of the trans-

Atlantic slave trade, conveyed to Europe and sold as laborers by the celebrated

“discoverer" Christopher Columbus. According to Jack Forbes, Columbus expressed his willingness on his first voyage to depopulate an entire island and transport its inhabitants to Spain for sale. Forbes quotes Columbus as follows: "when your highnesses so command, they can be carried off to Castile or held captive in the island itself, since with fifty men they would all be kept in subjugation and forced to do whatever may be wished" (1993, p. 22). During his first voyage Columbus only carried 25 kidnapped Amerindians back to Spanish slave markets. In subsequent voyages, he and the other Spaniards that followed in his wake transported thousands of Amerindians to be sold in Europe and Africa. Forbes estimates: “... at least 3,000 Americans are known to have been shipped to Europe between 1493 and 1501, with the likely total being possible double that" (1993, p. 24). He also notes that these Amerindians "wound up in the slave markets as negros" (Forbes, 1993, p. 24). The term negro, at this point in its ignominious history, did not exclusively denote people of African ancestry. As discussed at the 
beginning of this thesis, it was indiscriminately applied to individuals and groups based on subjective perceptions of dark skin color. But as Forbes clearly points out, by the end of the fifteenth century the term was associated with slavery and the exploitation and social debasement that slavery entailed. The semantic journey from negro as a generic term for slave (or, in a sense, non-white) to negro as a precise label for "black" slave, took place as a result of the decline in the numbers of European slaves entering the European markets coupled with the increase in supplies of "black" slaves due to Portuguese exploration and trade along the West African coast (Blackburn, 1997a).

Regardless of the lack of specificity of the term negro in the late medieval period, its use as a marker of difference provides an important context for understanding the evolution of its later pejorative permutations. Such notions of difference, viewed from the perspective of the Portuguese sailors raiding and exploring the West African coast in the mid-fifteenth century, provided a useful pretext for the capture and exploitation of its diverse populations. The Romanus Pontifex (1455)—a Papal Bull that justified and promoted the raiding and seizing of infidels and pagans as a kind of religious crusadespecifically authorized the acquisition of those "described as 'nigri' and inhabitants of Guinea" (Blackburn, 1997a, p. 103). In 1543, to tighten controls over transatlantic slave trafficking, the Spanish Crown issued an edict that: "mulatos and other slaves 'who are not Negroes' were forbidden to go to the Americas without a special license" (author's italics) (Forbes, 1993, p. 66). Thus "negro" functioned as a form of color coding or branding, a label that dehumanized "Africans" (and others) for commercial purposes, long before it became a pseudo-scientific description of supposed inferior "racial" characteristics to justify their commodification. This refutes the claims of racialist 
historians who have attempted to make "negro," from its inception, synonymous with "slave." Slavery in Europe preceded the racialization of slavery in the Americas. "Africans" were introduced into the Europe's slave culture mostly as pagans and infidels, as non-Christians who labored alongside Christian and non-Christian slaves of European origins. Central Europe's Slavic communities (and their neighbors to the north and east) constituted the principal sources of slaves in Europe in the centuries prior to the establishment of the Atlantic trade: hence the derivations of the word "slave" in virtually every language in Western Europe. As William McKee Evans notes: "During the later Middle Ages certain Caucasian peoples such as the Circassians, the Abkhaz, and the Mingrelians were scarcely known outside their native region except as slaves" (1980, p. 24). These traditional sources from the Balkans and the Black Sea were redirected to the Islamic world after the Ottoman capture of Constantinople in 1453 (Davis, 1984, p. 56). By this time, however, Portuguese sailors were successfully raiding the coastline of Upper Guinea and transporting captive "Africans" to slave markets in Lisbon. Due to African resistance, raiding proved to be an inefficient means of supplying the increasingly demanding market. The Portuguese then established diplomatic and commercial relations with the elites in coastal African societies in Upper Guinea and southward as they explored more of the West African coastline (Thornton, 1998, p. 43).

West Africa had been linked for centuries to Mediterranean commerce via the trans-Saharan trade through commercial networks that preceded the violent and brutal Islamification of North Africa. As Samir Amin points out: "the displacement of the center of emerging capitalism from the Mediterranean towards the Atlantic was to kindle a crisis in Africa" (1997, p. 39). This shift meant that Africans would now enter the systems of 
trade and commerce from two directions (across the Sahara and from the Atlantic ocean), thus further draining the manpower and womanpower of African polities. With the development of these new sources, the numbers of "black" people routinely entering the Iberian Peninsula and other sectors of Mediterranean Europe dramatically increased. The intense mercantilist focus on West Africa as an inexhaustible source of cheap laborers resulted in the "negrofication" of its diverse populations irrespective of their ethnic and linguistic distinctions. As Evans points out, the Sons of Ham were suddenly transplanted to Upper Guinea in a location that happened to be "not far from the major trade-wind, sailing route between Europe and the Americas" (1980, p. 37). Thus the late medieval and early modern form of "negro" was invented from Yoruba, Akan, Fon, Kongo and myriad other "African" ethnicities to serve the hegemonic interests of European capitalism and religion, and Europe's colonial expansion into the Americas. Racial or not, the conflation of "negro" with "slave" at this precise historical juncture marked a decisive turning point in the social construction of "white" and "black" identities.

It also must be remembered that the word "African," regardless of its original derivation, comes into common usage as a designation for the continent and its inhabitants from the Latin language and its Roman speakers who conquered millions of “Africans" and colonized a large portion of North African territory (Snowden, 1970, pp. 11-16). To be an African (or negro), especially in the "modern" sense of the term, implies the tacit or complicit acceptance of a sociohistorical label or identity imposed by nonAfricans who were asserting the hegemonic prerogatives of colonizers in defining both the land and its peoples for the purposes of control, exploitation and assimilation. Seen from this perspective, the first half of Fanon's remark quoted above- "It is the white man 
who creates the Negro"- generally describes the Euro-American social construction of race and its imposition on non-Europeans through enslavement, conquest and colonization during the later stages of the transatlantic trade. Whereas the second half"But it is the Negro who creates Negritude"—describes the "African" or "black" adaptive response and reaction to the process of racialization in the Americas. This discussion of the invention of the "negro" by non-Africans posits a foundation upon which to examine how and when "blacks" in the Americas began to refer to themselves collectively as "Africans." To follow the implications of this process it is necessary to explore how the shocking arrival and immersion of "Africans" in the new world slaveocracies catalyzed the formation of "black" diasporan identity. Such a study would complete the examination of the two templates that led to the formation of modern "black" identity: the stereotypic negative images fostered and imposed by the slave trade, and the positive ethnic attributes that informed the self-conceptions and perceptions of "Africans" within their own indigenous cultures and societies. In pursuing the further study of this subject, especially the notion of the invention of Negritude or Afrocentricity, it will be important once again to look at the role of religion—monotheism and cosmotheism—in forming and informing the critical didactic and discursive tools of "black" resistance and selfdetermination. Such an approach recognizes the ideological nature of Afrocentric thought, and the fact that many of the founders of this discourse in America, Prince Hall, Samuel Cornish, Frederick Douglass and their scholar-activist compatriots, were "black" ministers devoted to realizing the universal humanism embodied in some aspects of Christian discourse and didacticism. 
In parsing these difficult subjects, I have attempted to look forward from their specific geographical and cultural contexts, not backward through the modern lens of racialism. Although the subject is the formation of early modern racial identities, the predicate involves ancient and medieval notions of ethnicity and identity that cannot be categorized according to modern conceptions of race. In exploring the role of the three western monotheisms (Judaism, Christianity and Islam) in the formation of antiblack racism I have taken a heuristic approach that often raised many more questions than provided answers. Nevertheless, I remain confident that I have exposed the basic building blocks of Eurocentrism and antiblack racism—the foundational materials from which the "master's house" has been constructed. With this modest blueprint in hand, those engaged in the crucial task of dismantling the "master's house" have access to additional discursive tools specifically designed to achieve this vision and mission. 


\section{REFERENCES}

Adamo, D. T. (1986). The Place of Africa and Africans in the Old Testament and Its Environment (Black, Contribution). Unpublished Ph.D., Baylor University, United States -- Texas.

al-Azmeh, A. (1992). Barbarians in Arab Eyes. Past and Present, 134, 3-18.

al-Jahiz, U. A. I. B. (1981). The Book of the Glory of the Black Race. Los Angeles: France Preston.

al-Rawandi, I. (2000). Origins of Islam: A Critical Look at the Sources. In I. Warraq (Ed.), The Quest for the Historical Muhammad (pp. 89-124). Amhert, NY: Prometheus Books.

Ali, A. Y. (1983). The Holy Qur'an: Text, Translation and Commentary. Brentwood, Md.: Amana Corp.

Allen, T. W. (1994). The Invention of the White Race (Vol. One). London: Verso.

Amin, S. (1989). Eurocentrism. New York: Monthly Review Press.

Amin, S. (1997). Trans-Saharan Exchange and the Black Slave Trade. Diogenes, 45(179), 31-47.

Andriolo, K. R. (1973). A Structural Analysis of Genealogy and Worldview in the Old Testament. American Anthropologist, 75(5), 1657-1669.

Appiah, A. (1992). In My Father's House: Africa in the Philosophy of Culture. New York: Oxford University Press. 
Applegate, L. R. (2000). Zoroastrianism and Its Probable Influence on Judaism and Christianity. Journal of Religion \& Psychical Research, 23(4), 184.

Armstrong, K. (1993). A History of God: The 4,000 Year Quest of Judaism, Christianity and Islam. New York: Ballantine.

Asante, M. K. (1998). The Afrocentric Idea. Philadelphia: Temple University Press.

Ashcroft, B., Griffiths, G., \& Tiffin, H. (1998). Key Concepts in Post-Colonial Studies. London; New York: Routledge.

Aslan, R. (2006). No God but God: The Origins, Evolution, and Future of Islam. New York: Random House Trade Paperbacks.

Assmann, J. (1996). The Mosaic Distinction: Israel, Egypt, and the Invention of Paganism. Representations(56), 48-67.

Assmann, J. (1997). Moses the Egyptian: The Memory of Egypt in Western Monotheism. Cambridge, Mass.: Harvard University Press.

Assmann, J. (2001). The Search for God in Ancient Egypt (1st English-language ed.). Ithaca: Cornell University Press.

Augustine. (1987). City of God (M. Dods, Trans.). In Augustine (pp. 129-618). Chicago: Encyclopedia Britannica, Inc.

Bachofen, J. J. (1926). Myth, Religion, \& Mother Right. Princeton: Princeton University Press.

Bacon, J. (2003). The History of Freedom's Journal: A Study in Empowerment and Community. The Journal of African American History, 88(1), 1.

Bastide, R. (1967). Color, Racism and Christianity. Daedalus, 96, 312-327.

Berg, H. (2000). The Implications of, and Opposition to, the Methods and Theories of John Wansbrough (I. Warraq, Trans.). In I. Warraq (Ed.), The Quest for the Historical Muhammad (pp. 489-509). Amherst, NY: Prometheus Books. 
Berger, P. L., \& Luckmann, T. (1967). The Social Construction of Reality: A Treatise in the Sociology of Knowledge. New York: Anchor Books.

Bernal, M. (1987). Black Athena: The Afroasiatic Roots of Classical Civilization (Vol. I: The Fabrication of Ancient Greece 1785-1985). New Brunswick, N.J.: Rutgers University Press.

Blackburn, R. (1997a). The Making of New World Slavery: From the Baroque to the Modern, 1492-1800. London; New York: Verso.

Blackburn, R. (1997b). The Old World Background to European Colonial Slavery. The William and Mary Quarterly, 54(1), 65-102.

Blaut, J. M. (1993). The Colonizer's Model of the World : Geographical Diffusionism and Eurocentric History. New York: Guilford Press.

Blaut, J. M. (2000). Eight Eurocentric Historians. New York: Guilford Press.

Bostom, A. G. (Ed.). (2005). The Legacy of Jihad: Islamic Holy War and the Fate of Non-Muslims. Amherst, NY: Prometheus Books.

Brace, C. L. (2005). "Race" Is a Four-Letter Word: The Genesis of the Concept. New York: Oxford University Press.

Braude, B. (1997). The Sons of Noah and the Construction of Ethnic and Geographical Identities in the Medieval and Early Modern Periods. The William and Mary Quarterly, 54(1), 103-142.

Breisach, E. (1994). Historiography: Ancient, Medieval \& Modern (2nd ed.). Chicago: University of Chicago Press.

Brockelmann, C. (1960). History of the Islamic Peoples. New York: Capricorn Books.

Bruce, D. D., Jr. (2001). The Origins of African American Literature: 1680-1865. Charlottesville: University Press of Virginia

Brunson, J. E., \& Rashidi, R. (1992). The Moors in Antiquity. In I. Van Sertima (Ed.), Golden Age of the Moor (pp. 27-84). New Brunswick: Transaction Publishers. 
Byron, G. L. (2002). Symbolic Blackness and Ethnic Difference in Early Christian Literature. London: Routledge.

Carew, J. (1992). Moorish Culture Bringers: Bearers of Enlightenment. In I. Van Sertima (Ed.), Golden Age of the Moor (pp. 248-277). New Brunswick: Transaction Publishers.

Carew, J. (1994). The Rape of Paradise: Columbus and the Birth of Racism in the Americas. Brooklyn, N.Y.: A\&B Books.

Carew, J. R. (1988). Fulcrums of Change. Trenton, N.J.: Africa World Press.

Carretta, V., \& Gould, P. (Eds.). (2001). Genius in Bondage: Literature of the Early Black Atlantic. Lexington: The University Press of Kentucky.

Carroll, M. P. (1985). A Structuralist Exercise: The Problem of Moses' Name. American Ethnologist, 12(4), 775-778.

Cesairé, A. (1972). Discourse on Colonialism (J. Pinkham, Trans.). New York: Monthly Review Press.

Chandler, W. B. (1992). The Moor: Light of Europe's Dark Age. In I. Van Sertima (Ed.), Golden Age of the Moor (pp. 151-181). New Brunswick: Transaction Publishers.

Chinweizu. (1975). The West and the Rest of Us. New York: Vintage Books.

Choksy, J. K. (2003). Hagiography and Monotheism in History: Doctrinal Encounters between Zoroastrianism, Judaism and Christianity Islam \& Christian-Muslim Relations, 14(4), 407.

Churchill, W. (1997). A Little Matter of Genocide: Holocaust and Denial in the Americas, 1492 to the Present. San Francisco: City Lights Books.

Cox, O. C. (1945). Race and Caste: A Distinction. The American Journal of Sociology, 50(5), 360-368.

Cox, O. C. (1948). Caste, Class and Race. Phylon (1940-1956), 9(2), 171-172. 
Crone, P. (1987). Meccan Trade and the Rise of Islam. Princeton, N.J.: Princeton University Press.

Crossan, J. D. (1998). The Birth of Christianity. New York: HarperCollins.

Curtin, P. D. (1969). The Atlantic Slave Trade: A Census. Madison: The University of Wisconsin Press.

Darwin, C. (1871). The Descent of Man, and Selection in Relation to Sex. New York,: D. Appleton and company.

Davis, D. B. (1984). Slavery and Human Progress. New York: Oxford University Press.

deGraft-Johnson, J. C. (1954). African Glory. Toronto: George J. McLeod, Limited.

Diamond, J. M. (1997). Guns, Germs, and Steel: The Fates of Human Societies (1st ed.). New York: W.W. Norton.

Diggins, J. P. (1976). Slavery, Race, and Equality: Jefferson and the Pathos of the Enlightenment. American Quarterly, 28(2), 206-228.

Diop, C. A. (1974). The African Origin of Civilization: Myth or Reality. New York: Lawrence Hill.

Diop, C. A. (1978). The Cultural Unity of Black Africa: The Domains of Patriarchy and of Matriarchy in Classical Antiquity. Chicago: Third World Press.

Douglass, F. (1854). The Claims of the Negro Ethnologically Considered. In P. S. Foner (Ed.), Frederick Douglass: Selected Speeches and Writings (pp. 282-297). Chicago: Lawrence Hill Books.

Dover, C. (1952). The Racial Philosophy of Ibn Khaldun. Phylon (1940-1956), 13(2), 107-119.

Drake, S. C. (1987). Black Folk Here and There: An Essay in History and Anthropology (Vol. 1). Los Angeles: Center for Afro-American Studies, University of California. 
Drake, S. C. (1990). Black Folk Here and There: An Essay in History and Anthropology (Vol. 2). Los Angeles: Center for Afro-American Studies, University of California.

Du Bois, W. E. B. (1946). The World and Africa (1st ed.). New York: Viking.

Duncan, D. E. (1998). Calendar: Humanity's Epic Struggle to Determine a True and Accurate Year (1st ed.). New York: Bard.

Dussel, E. (1993). Eurocentrism and Modernity (Introduction to the Frankfort Lectures). boundary 2, 20(3), 65-78.

Dussel, E. (2000). Europe, Modernity, and Eurocentrism. Nepantia: Views from South, $1(3), 455-478$.

Ephal, I. (1976). Ishmael and Arab(S): A Transformation of Ethnological Terms. Journal of Near Eastern Studies, 35(4), 225-235.

Ernest, J. (2004). Liberation Historiography: African American Writers and the Challenge of History, 1794-1861. Chapel Hill: University of North Carolina Press.

Evangeliou, C. (2003). Dangerous Deviations of Judaism: Islamic and Christian Fanaticism. Mediterranean Quarterly, 14(3), 86-111.

Evans, W. M. (1980). From the Land of Canaan to the Land of Guinea: The Strange Odyssey of The "Sons of Ham". The American Historical Review, 85(1), 15-43.

Eze, E. C. (1997). Race and the Enlightenment: A Reader. Cambridge, Mass.: Blackwell.

Fabian, J. (2002). Time and the Other : How Anthropology Makes Its Object. New York: Columbia University Press.

Fabian, J. (2006). The Other Revisited: Critical Afterthoughts. Anthropological Theory, $6(2), 139-152$.

Fanon, F. (1965). The Wretched of the Earth. New York: Grove Press. 
Fanon, F. (1967). A Dying Colonialism. New York: Evergreen.

Fanon, F., \& Markmann, C. L. (1968). Black Skin, White Masks. New York: Grove Press.

Fideler, D. (1993). Jesus Christ Sun of God: Ancient Cosmology and Early Christian Symbolism. Wheaton: Quest Books.

Finch, C. I. (1988). Africa and Palestine in Antiquity. In I. Van Sertima \& R. Rashidi (Eds.), African Presence in Early Asia (pp. 187-197). New Brunswick: Transaction Books.

Finch, C. S. (1992). Echoes of the Old Darkland. Decarur, GA.: Khenti, Inc.

Finkelstein, I., \& Silberman, N. A. (2001). The Bible Unearthed: Archaeology's New Vision of Ancient Israel and the Origin of Its Sacred Texts. New York: Free Press.

Finley, M. I. (1998). Ancient Slavery and Modern Ideology. Princeton: Markus Wiener Publishers.

Fischer, D. H. (1970). Historians' Fallacies: Toward a Logic of Historical Thought. New York: Harper Torchbooks.

Fletcher, R. (1992). Moorish Spain. Berkeley: University of California Press.

Flexner, S. B. (Ed.) (1987) The Random House Dictionary of the English Language (2nd ed.). New York: Random House.

Forbes, J. D. (1993). Africans and Native Americans: The Language of Race and the Evolution of Red-Black Peoples (2nd ed.). Urbana: University of Illinois Press.

Foucault, M. (1994). The Order of Things: An Archaeology of the Human Sciences. New York: Vintage Books.

Foucault, M., Bertani, M., Fontana, A., Ewald, F., \& Macey, D. (2003). "Society Must Be Defended": Lectures at the Collège De France, 1975-76 (1st ed.). New York: Picador. 
Fox, R. L. (1986). Pagans and Christians. New York: Alfred A. Knopf, Inc.

Fredrickson, G. M. (2002). Racism: A Short History. Princeton, N.J.: Princeton University Press.

Fregosi, P. (1998). Jihad. Amherst: Prometheus Books.

Freud, S. (1967). Moses and Monotheism. New York: Vintage.

Frost, P. (1991). Attitudes Towards Blacks in the Early Christian Era. The Second Century: A Journal of Early Christian Studies, 8(1), 1-11.

Gilroy, P. (1993). The Black Atlantic: Modernity and Double Consciousness. Cambridge, MA: Harvard University Press.

Goldenberg, D. M. (2003). The Curse of Ham: Race and Slavery in Early Judaism, Christianity, and Islam. Princeton, N.J.: Princeton University Press.

Gomez, M. A. (1998). Exchanging Our Country Marks: The Transformation of African Identities in the Colonial and Antebellum South. Chapel Hill: The University of North Carolina Press.

Goody, J. (1986). The Logic of Writing and the Organization of Society. Cambridge [Cambridgeshire] ; New York: Cambridge University Press.

Goody, J. (2004). Islam in Europe. Cambridge, UK

Malden, MA: Polity Press ;

Distributed in the USA by Blackwell Pub.

Goody, J. (2006). The Theft of History. Cambridge ; New York: Cambridge University Press.

Gordon, L. R. (1997). Her Majesty's Other Children: Sketches of Racism from a Neocolonial Age. Lanham, Md.: Rowman \& Littlefield.

Gordon, L. R., \& Gordon, J. A. (2006a). Introduction: Not Only the Master's Tools. In L. R. Gordon \& J. A. Gordon (Eds.), Not Only the Master's Tools: African American Studies in Theory and Practice (pp. ix-x1). Boulder: Paradigm Publishers. 
Gordon, L. R., \& Gordon, J. A. (2006b). Not Only the Master's Tools: African-American Studies in Theory and Practice. Boulder: Paradigm.

Graves, R., \& Patai, R. (1983). Hebrew Myths: The Book of Genesis. New York: Greenwich House

Green, W. A. (1995). Periodizing World History. History \& Theory, 34(2), 99.

Greenberg, G. (1996). The Moses Mystery: The African Origins of the Jewish People. Secaucus, N.J.: Carol Publishing Group.

Greenberg, G. (2000). Myths of the Bible: How Ancient Scribes Invented Biblical History. Naperville, IL: Sourcebook, Inc.

Greenberg, J. H. (1966). The Languages of Africa ([2d ed.). Bloomington,: Indiana University.

Hall, K. F. (1995). Things of Darkness: Economies of Race and Gender in Early Modern England. Ithaca: Cornell University Press.

Hammond, R. A., \& Axelrod, R. (2006). The Evolution of Ethnocentrism. Journal of Conflict Resolution, 50(6), 926-936.

Hannaford, I. (1996). Race: The History of an Idea in the West. Washington, D.C.: Woodrow Wilson Center Press

Heaton, E. W. (1974). Solomon's New Men: The Emergence of Ancient Israel as a Nation State. New York: Pica Press.

Hobson, J. M. (2004). The Eastern Origins of Western Civilization. Cambridge, UK ; New York: Cambridge University Press.

Holloway, J. E. (1990). The Origins of African American Culture. In J. E. Holloway (Ed.), Africanisms in American Culture (pp. 1-18). Bloomington: Indiana University Press. 
Hood, R. E. (1994). Begrimed and Black: Christian Traditions on Blacks and Blackness. Minneapolis, Minn.: Augsburg Fortress.

Houston, D. D. (1926). Wonderful Ethiopians of the Ancient Cushite Empire. Baltimore: Black Classic Press.

Howe, S. (1998). Afrocentrism: Mystical Pasts and Imagined Homes. London: Verso.

Hunwick, J. O., \& Powell, E. T. (2002). The African Diaspora in the Mediterranean Lands of Islam. Princeton: Markus Wiener Publishers.

Ignatiev, N. (1995). How the Irish Became White. New York: Routledge.

Irving, W. (1885). The Conquest of Granada. New York: James B. Millar \& CO.

Irwin, G. W. (1977). Africans Abroad: A Documentary History of the Black Diaspora in Asia, Latin America, and the Caribbean During the Age of Slavery. New York: Columbia University Press.

Isaac, B. (2006). Proto-Racism in Graeco-Roman Antiquity. World Archaeology, 38(1), $32-47$.

Isaac, B. H. (2004). The Invention of Racism in Classical Antiquity. Princeton, N.J.: Princeton University Press.

Jackson, J. G. (1970). Introduction to African Civilizations. Secaucus: The Citadel Press.

Jackson, J. G. (1985). Christianity before Christ. Austin: American Atheist Press.

James, G. G. M. (1954). Stolen Legacy: The Greeks Were Not the Authors of Greek Philosophy, but the People of North Africa, Commonly Called the Egyptians. San Francisco: Julian Richardson Associates, Publishers.

JanMohammed, A. R. (1985). The Economy of Manichean Allegory: The Function of Racial Difference in Colonial Literature. Critical Inquiry, 12(1), 59-87. 
Jordan, W. D. (1968). White over Black: American Attitudes toward the Negro, 15501812. Chapel Hill,: Published for the Institute of Early American History and Culture at Williamsburg, Va.

Jordan, W. D. (1974). The White Man's Burden: Historical Origins of Racism in the United States. New York,: Oxford University Press.

Kanneh, K. (1998). African Identities: Race, Nation and Culture in Ethnography, PanAfricanism and Back Literatures. London: Routledge.

Keita, M. (1994). Deconstructing the Classical Age: Africa and the Unity of the Mediterranean World. The Journal of Negro History, 79(2), 147-166.

Keita, M. (2000). Race and the Writing of History: Riddling the Sphinx. Oxford ; New York: Oxford University Press.

Keita, M. (2001). Conceptualizing/Re-Conceptualizing Africa: The Construction of African Historical Identity. Journal of Asian \& African Studies (Brill), 36(4), 331337.

Keita, M. (2002). Race, the Writing of History, and Culture Wars. Journal of Black Studies, 33(2), 166-178.

Keita, M. (2005). Africans and Asians: Historiography and the Long View of Global Interaction. Journal of World History, 16(1), 1-30.

Kilcher, A. B. (2004). The Moses of Sinai and the Moses of Egypt: Moses as Magician in Jewish Literature and Western Esotericism. Aries, 4(2), 148-170.

Kirsch, J. (2004). God against the Gods: The History of the War between Monotheism and Polytheism. New York: Viking Compass.

Klein, H. S. (1999). The Atlantic Slave Trade. Cambridge: Cambridge University Press.

Klein, M. (1992). The Impact of the Atlantic Slave Trade on the Societies of the Western Sudan. In J. E. Inikori \& S. L. Engerman (Eds.), The Atlantic Slave Trade: Effects on Economies, Societies, and Peoples in Africa, the Americas, and Europe (pp. 25-47). Durham: Duke University Press. 
Lammens, H. (1910). The Koran and Tradition: How the Life of Muhammad Was Composed (I. Warraq, Trans.). In I. Warraq (Ed.), The Quest for the Historical Muhammad (pp. 169-187). Amherst, NY: Prometheus Books.

Lane-Poole, S. (1886). The Story of the Moors in Spain. Baltimore: Black Classic Press.

Lefkowitz, M. (1997). Not out of Africa: How Afrocentrism Became an Excuse to Teach Myth as History. New York: Basic Books.

Lester, T. (2002). What Is the Koran? (I. Warraq, Trans.). In I. Warraq (Ed.), What the Koran Really Says: Language, Text, \& Commentary (pp. 107-128). Amherst, NY: Prometheus.

Lewis, B. (1982). The Muslim Discovery of Europe (1st ed.). New York: W.W. Norton \& Company.

Lewis, B. (1985). The Crows of the Arabs. Critical Inquiry, 12(1), 88-97.

Lincoln, B. (1989). Discourse and the Construction of Society: Comparative Studies of Myth, Ritual and Classification. Oxford: Oxford University Press.

Livingstone, F. B., \& Dobzhansky, T. (1962). On the Non-Existence of Human Races. Current Anthropology, 3(3), 279-281.

Lorde, A. (1984). Sister Outsider: Essays and Speeches. Trumansburg, NY: Crossing Press.

Manning, P. (1992). The Slave Trade: The Formal Demography of a Global System. In J. E. Inikori \& S. L. Engerman (Eds.), The Atlantic Slave Trade: Effects on Economies, Societies, and Peoples in Africa, the Americas, and Europe (pp. 117141). Durham: Duke University Press.

Massey, G. (1907a). Ancient Egypt the Light of the World (Vol. 2). Baltimore: Black Classic Press.

Massey, G. (1907b). Ancient Egypt the Light of the World (Vol. 1). Baltimore: Black Classic Press. 
Mastnak, T. (2002). Crusading Peace: Christendom, the Muslim World and Western Political Order. Berkeley: University of California Press.

McElvaine, R. S. (2001). Eve's Seed: Biology, the Sexes, and the Course of History. New York: McGraw-Hill.

Menocal, M. R. (2002). The Ornament of the World: How Muslims, Jews, and Christians Created a Culture of Tolerance in Medieval Spain. Boston: Little, Brown.

Mignolo, W. (1995). The Darker Side of the Renaissance: Literacy, Territoriality, \& Colonization. Ann Arbor: The University of Michigan Press.

Mignolo, W. (2000). Local Histories/Global Designs: Coloniality, Subaltern Knowledges, and Border Thinking. Princeton, N.J.: Princeton University Press.

Miller, J. C. (1988). Way of Death: Merchant Capitalism and the Angolan Slave Trade 1730-1830. Madison: The University of Wisconsin Press.

Mills, C. W. (1997). The Racial Contract. Ithaca: Cornell University Press.

Mills, S. (2004). Discourse. London; New York: Routledge.

Moser, B. (1999). The Holy Bible: Containing All the Books of the Old and New Testaments: King James Version. New York: Viking Studio.

Moses, W. J. (1998). Afrotopia: The Roots of African American Popular History. Cambridge [England] ; New York: Cambridge University Press.

Mudimbe, V. Y. (1988). The Invention of Africa: Gnosis, Philosophy, and the Order of Knowledge. Bloomington: Indiana University Press.

Nancy, J. L. (2003). Deconstruction of Monotheism Postcolonial Studies, 6(1), 37-46.

Nietzsche, F. W. (1957). The Use and Abuse of History (A. Collins, Trans. 2d rev. ed.). Indianapolis,: Bobbs-Merrill Educational Publishing. 
Oliver, R. (1991). The African Experience: Major Themes in African History from Earliest Times to the Present. New York: HarperCollins.

Ortiz, F. (1995). Cuban Counterpoint: Tobacco and Sugar. Durham: Duke University Press.

Osman, A. (1990). Moses: Pharoah of Egypt. London: Paladin.

Patterson, O. (1982). Slavery and Social Death: A Comparative Study. Cambridge, Mass.: Harvard University Press.

Patterson, O. (1998). Rituals of Blood: Consequences of Slavery in Two American Centuries. Washington, D.C.: Civitas/CounterPoint.

Peters, F. E. (1991). The Quest of the Historical Muhammad. International Journal of Middle East Studies, 23(3), 291-315.

Peters, F. E. (2003a). The Monotheists: Jews, Christians, and Muslims in Conflict and Competition (Vol. II: Th Words and Will of God). Princeton: Princeton University Press.

Peters, F. E. (2003b). The Monotheists: Jews, Christians, and Muslims in Conflict and Competition (Vol. I: The Peoples of God). Princeton: Princeton University Press.

Piedra, J. (1993). The Black Stud's Spanish Birth. Callaloo, 16(4), 820-846.

Pimienta-Bey, J. V. (1992). Moorish Spain: Academic Source and Foundation for the Rise and Success of Western European Universities in the Middle Ages. In I. Van Sertima (Ed.), Golden Age of the Moor (pp. 182-247). New Brunswick: Transaction Publishers.

Pipes, D. (1980). Black Soldiers in Early Muslim Armies. The International Journal of African Historical Studies, 13(1), 87-94.

Porter, R. (2000). The Creation of the Modern World: The Untold Story of British Enlightenment. New York: W. W. Norton \& Company, Inc. 
Preston, W. (1981). Postscript. In W. Preston (Ed.), The Book of the Glory of the Black Race (pp. 65-68). Los Angeles: France Preston.

Rabasa, J. (1993). Inventing a-M-E-R-I-C-A: Spanish Historiography and the Formation of Eurocentrism. Norman, OK: University of Oklahoma Press.

Rael, P. (2002). Black Identity \& Black Protest in the Antebellum North. Chapel Hill: University of North Carolina Press.

Redford, D. B. (1984). Akhenaten: The Heretic King. Princeton: Princeton University Press.

Reinking, A. (2005). Islam as a Continuation of Judeo-Christian Monotheism. Unpublished M.A., California State University, Dominguez Hills, United States -California.

Roach, J. (1996). Cities of the Dead: Circum-Atlantic Performance. New York: Columbia University Press.

Robins, G. (1993). Women in Ancient Egypt. Cambridge, MA: Harvard University Press.

Rodney, W. (1974). How Europe Underdeveloped Africa. Washington, D.C.: Howard University Press.

Rogers, J. A. (1946). World's Great Men of Color. New York: Helga M. Rogers.

Rogers, J. A. (1952). Nature Knows No Color-Line (3rd ed.). New York: Helga M. Rogers.

Rubenstein, R. E. (2003). Aristotle's Children: How Christians, Muslims, and Jews Rediscovered Ancient Wisdom and Illuminated the Dark Ages. Orlando: Harcourt, Inc.

Said, E. W. (1994). Orientalism. New York: Vintage Books.

Sale, M. M. (1997). The Slumbering Volcano: American Slave Ship Revolts and the Production of Rebellious Masculinity. Durham: Duke Universiy Press. 
Sanders, E. R. (1969). The Hamitic Hypothesis: Its Origin and Functions in Time Perspective. The Journal of African History, 10(4), 521-532.

Schniedewind, W. M. (2004). How the Bible Became a Book. Cambridge: Cambridge University Press.

Schorsch, J. (2004). Jews and Blacks in the Early Modern World. New York: Cambridge University Press.

Schwartz, R. M. (1997). The Curse of Cain: The Violent Legacy of Monotheism. Chicago: University of Chicago Press.

Segal, R. (2001). Islam's Black Slaves: The Other Black Diaspora (1st ed.). New York: Farrar, Straus and Giroux.

Shavit, J. (2001). History in Black: African-Americans in Search of an Ancient Past. London ; Portland, OR: Frank Cass.

Shaw, B. D. (1998). A Wolf by the Ears. In B. D. Shaw (Ed.), Ancient Slavery and Modern Ideology (pp. 3-74). Princeton: Markus Wiener Publishers.

Smith, M. S. (2001). The Origins of Biblical Monotheism: Israel's Polytheistic Background and the Ugaritic Texts. New York: Oxford University Press.

Snowden, F. M. (1970). Blacks in Antiquity: Ethiopians in the Greco-Roman Experience. Cambridge, MA: Belknap Press of Harvard University Press.

Snowden, F. M. (1983). Before Color Prejudice: The Ancient View of Blacks. Cambridge, Mass.: Harvard University Press.

Sollors, W. (1997). Neither Black nor White yet Both: Thematic Explorations of Interracial Literature. New York: Oxford University Press.

Stark, R. (2003). For the Glory of God: How Monotheism Led to Reformations, Science, Witch-Hunts, and the End of Slavery. Princeton: Princeton University Press.

Stein, G. (1971). Everybody's Autobiography. New York,: Cooper Square Publishers. 
Sweet, J. H. (1997). The Iberian Roots of American Racist Thought. The William and Mary Quarterly, 54(1), 143-166.

Thompson, L. A. (1989). Romans and Blacks. Norman: University of Oklahoma Press.

Thompson, T. (1999). The Mythic Past: Biblical Archaeology and the Myth of Israel. New York: Basic Books.

Thompson, T. L. (2005). The Messiah Myth: The near Eastern Roots of Jesus and David. New York: Basic Books.

Thornton, J. (1998). Africa and Africans in the Making of the Atlantic World, 1400-1800 (2nd ed.). Cambridge: Cambridge University Press.

Tibi, B. (2005). War and Peace in Islam. In A. G. M. Bostom (Ed.), The Legacy of Jihad: Islamic Holy War and the Fate of Non-Muslims (pp. 326-342). Amherst, NY: Prometheus Books.

Trafton, S. (2004). Egypt Land: Race and Nineteenth-Century American Egyptomania. Durham: Duke University Press.

Van Sertima, I. (1985). African Presence in Early Europe. New Brunswick [N.J.], U.S.A.: Transaction Books.

Van Sertima, I. (Ed.). (1992). Golden Age of the Moor. New Brunswick: Transaction Publishers.

Warraq, I. (1998a). Introduction. In I. Warraq (Ed.), The Orgins of the Koran (pp. 9-35). Amherst, NY: Prometheus Books.

Warraq, I. (1998b). The Origins of the Koran: Classic Essays on Islam's Holy Book. Amherst, N.Y.: Prometheus Books.

Warraq, I. (2000a). Studies on Muhammad and the Rise of Islam: A Critical Survey (I. Warraq, Trans.). In I. Warraq (Ed.), The Quest for the Historical Muhammad (pp. 15-88). Amherst, NY: Prometheus Books. 
Warraq, I. (Ed.). (2000b). The Quest for the Historical Muhammad. Amherst, NY: Prometheus Books.

Wellard, J. (1964). The Great Sahara. London: Hutchinson \& Co.

Williams, C. (1974). The Destruction of Black Civilization: Great Issues of a Race from 4500 B.C. To 2000 A.D. Chicago: Third World Press.

Williams, E. E. (1994). Capitalism \& Slavery. Chapel Hill: University of North Carolina Press.

Williams, J. A. (Ed.). (1962). Islam. New York: George Braziller.

Wilson, A. N. (1992). Jesus: A Life. New York: Fawcett Columbine.

Wright, M. M. (2004). Becoming Black: Creating Identity in the African Diaspora. Durham: Duke University Press.

Young, R. (1990). White Mythologies: Writing History and the West. London ; New York: Routledge.

Young, R. (1995). Colonial Desire: Hybridity in Theory, Culture, and Race. London ; New York: Routledge.

Zabkar, L. V. (1954). The Theocracy of Amarna and the Doctrine of the Ba. Journal of Near Eastern Studies, 13(2), 87-101.

Zizek, S. (2002). Welcome to the Desert of the Real: Five Essays on September 11 and Related Dates. London: Verso.

Zlotnick-Sivan, H. (2004). Moses the Persian? Exodus 2, the Other and Biblical Mnemohistory. Zeitschrift für die Alttestamentliche Wissenschaft, 116, 189. 


\section{CURRICULUM VITAE}

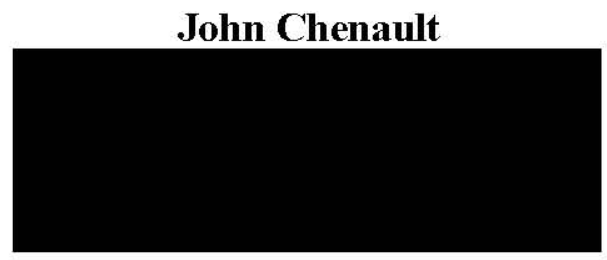

\section{Education}

2007

2006

1977

1975

2003-Present
University of Louisville

M.A. in Pan African Studies

University of Kentucky

M.S. in Library and Information Science

Union Institute

B.F.A., Interdisciplinary Majors in Music and Creative Writing; minors in African and African American Studies. PDE (Project Demonstrating Excellence/Senior Thesis):

"African Genesis: the role of Africa in human development."

\section{Antioch College}

Coursework in creative writing, film, music theory, African American literature.

\section{Employment History}

University of Louisville: Kornhauser Health Science

Library. Instructor/Reference Librarian providing information literacy instruction, citation management training, and research assistance to the UofL Medical Campus. 

Research Assistant providing editorial, clerical and archival support to Professor Jan Carew for various writing projects.

1994-2002

Liben Music, Inc. Cincinnati, Ohio. Writer, composer, consultant for a music composition, recording and publishing business.

1996-2001

Young Enterprises. Fayetteville, Georgia. Consultant, proposal writer for wholesale art, art restoration, and arts education business.

1997-2000

Borders, Inc. Atlanta Georgia. Bookseller providing customer service, title search and recommendation, inventory control, and support for all areas of store operations.

1986-1994

Sickle Cell Awareness Group, Inc. Cincinnati, Ohio. Executive Director of a United Way-funded health education agency serving sickle cell clients, health educators and social workers. Conducted education programs, public health campaigns, workshops, seminars, and fundraising and grants programs. Developed budgets, maintained accounts, and supervised audits.

1979-1982 Washington International College. Washington, D.C. Executive Dean. Chief administrative officer of a Liberal Arts College with over-site for an International student body and staff. Provided leadership and direction in all areas of administration and academic affairs. Served as liaison to licensing and accrediting agencies. Supervised the maintenance of college records and accounts. Assisted in the development of core curriculum and individualized study programs. Developed Learning/Teaching/Managing/ Serving (LTMS) competency-based educational model for college-level individualized instruction. Orchestrated and implemented the affiliation of WIC with World University in Hato Rey, Puerto Rico.

1978-1982

Washington International College. Core and Adjunct Faculty.Taught African-American literature; literature of the African Diaspora; introduction to African music; survey of Black film. 
1977-1982

1977-1979

1976

1972

1993

1992

1992
Beacon College. Washington, D.C. Adjunct Faculty. Taught literature of the African Diaspora, and introduction to African-American literature.

Washington International College. Director of Special Services for Disadvantaged Students. Directed Department of Education-funded program to provide remedial instruction in math, reading and writing for under-prepared college students.

U.S. Library of Congress. Washington, D.C. Interlibrary Loan Clerk. Responsible for manual file maintenance of records for government, public and military interlibrary loans. Additional duties included routing and delivering library materials to Senate and Congressional offices as per a 24-hour service protocol.

University of Cincinnati. Afro-American Studies Department. Instructor. Taught seminar course on psychology of interracial relations.

\section{$\underline{\text { Publications }}$}

"More Roots Branches and Fruits: the Historical Relationship between Blacks and Native Americans." Artrage Magazine. London, UK. (Aug.).

"Where the Niger Meets the Congo: the Roots of AfroCuban Music.” Artrage Magazine. London, UK. (July).

"Lynching, Literature, and Rodney King." Artrage Magazine. London. UK (May): pp. 16-17.

"Roots Branches and Fruits of the African Tree of Life." Artrage Magazine. London, UK. (Mar.): pp. 6-7.

"Controversy in River City: The Ohio Arts Center Project Ignites a Firestorm of Protest.” Applause Magazine. Cincinnati, OH. (Jan.): pp. 32-35.

The Invisible Man Returns: selected poems. Cincinnati: Ventana Media.

"Civil Rights in the Nineties: Three Interviews." Applause Magazine. Cincinnati. OH. (Feb../Mar.): pp. 51-53, 90. 
"A Candid Interview with Superintendent Michael Brandt." Applause Magazine. Cincinnati. OH. (Sept.): pp. 43-46.

"Athol Fugard: The relentless voice of conscience." StageTwo. Cincinnati. OH. (Sept.): pp. 2-3.

"Spike Lee's Malcolm X." (Film review) Artrage Magazine. London. UK. (Dec.): pp. 32-33.

"Health and Wellness: Issues of Survival in the Twentieth Century." Applause Magazine. Cincinnati. OH. (May): pp. 36-40.

"The Black Madonna and Child: A History Ignored." Applause Magazine. Cincinnati, OH. (Dec./Jan.): pp. 4345.

"How to Save Your Life." (Book review) Applause Magazine. Cincinnati, OH. (Dec./Jan.): p. 22.

1978

1976

1975

1971

1969
"Four Poems." Confrontation: Journal of Third World Studies. Afro-American Studies Program, Ohio U. Athens, OH. (Winter) 2.3: pp 64-66.

"The Wake." BOP: Blacks on Paper. Afro-American Studies Department, Providence: Brown U. p. 49.

"Two Poems." Time Ta Greeze, An Anthology of Third World Literature. San Francisco: Glide/Third World Communications Press: pp. 87-89.

"To Gwen Brooks." To Gwen With Love: An Anthology Dedicated to Poet Gwendolyn Brooks. Chicago: Johnson Publications: pp 17-19.

Blue Blackness: selected poems. Cincinnati: Seven Hills. 


\section{$\underline{\text { Recent Papers/Lectures }}$}

2002

1999

1998

1996

1994

2006

2000

"Twentieth-Century Literature Conference." Chaired a conference section devoted to the works of poet/musician Nathaniel Mackey. University of Louisville, Feb. 23.

"The Cosmic Canon: Art and Architecture in Ancient Egypt." Atlanta College of the Arts, Atlanta, GA. Sept. 15.

"Eurocentrism and the Dilemma of Deep Time." Crossing the Stroke (Millennium) Lecture Series. EyeDrum Gallery. Atlanta, GA. Sept. 25.

"Langston Hughes and the Harlem Renaissance."

Humanities Department. Prairie State Community College, Forest Park, IL. Oct. 16.

"Human Evolution From an African Origin and Perspective." Amethyst Community Lecture Series. Cincinnati Art Museum. Cincinnati, OH. June 15.

"From Mother Nature to Human Nature: gender in human evolution, culture and civilization." National Herstory Month Conference. Cincinnati Museum Center. Cincinnati, OH. May 14.

\section{$\underline{\text { Dramas/Compositions }}$}

"The Tuner: A Musical Prophecy in Seven Scenes for Vocalist, Actors and Musicians." Commissioned 2005 by the International Society of Bassists. By Frank Proto and John Chenault. Dir. Charles Holmond. Perf. vocalist Carmen Baltrop, actor Reginald Willis, saxophones and clarinet Rick Van Matre, double bass and piano Frank Proto, additional voices John Chenault. Premiered Western Michigan University, Kalamazoo, June 11, 2006.

"My Name is Citizen Soldier: a music drama for orchestra and narrator." Commissioned (1999) by the American Composers Forum: Continental Harmony - New Music for the Millennium Project, for the tenth anniversary season of the Louisiana Philharmonic Orchestra, and to commemorate the opening of the National D-Day Museum. By Frank Proto and John Chenault. Dir. John Chenault. Conductor, Klauspeter Seibel. Performer, Paul Winfield, 
Louisiana Philharmonic Orchestra. Premiered, Orpheum Theater, New Orleans, LA. 14 Sept. 2000.

"The Fools of Time," a jazz composition for band and vocalist. Commissioned (1999) by the John F. Kennedy Center for the Performing Arts as part of the Louis Armstrong Legacy Series and the Kennedy Center's Millennium Season. By Frank Proto and John Chenault. Arr. and Cond. John Dankworth. Perf. Dame Cleo Laine and the John Dankworth Group. Premiered, John F. Kennedy Center for the Performing Arts, Washington, D.C. 11 Feb. 2000

1999

1998

1997

1996

1995

1993

1990
"Yesterday's News: a satire for jazz band with actors and vocalist." Commissioned (1998), University of Cincinnati College Conservatory of Music. By Frank Proto and John Chenault. Dir. John Chenault. Cond. Frank Proto. Perf. CCM Jazz Band. Premiered, Corbett Auditorium, Cincinnati, OH. 25 Apr. 1999.

Sanctuary: an original screenplay.

Chameleon: an original screenplay.

Stolen Moments: a two-act play.

The X-periment: a two-act play.

"Ghost in Machine: a music drama for vocalist, narrator, orchestra."

Commissioned for the 100th anniversary season of the Cincinnati Symphony Orchestra (CSO). By Frank Proto and John Chenault.

Cond. Jesus Lopez-Cobos. Dir. Charles Holmond. Perf. Cincinnati Symphony Orchestra, vocalist Cleo Laine, actor Paul Winfield. Premiered, Music Hall, Cincinnati. OH. 28 Apr. 1995.

The Buckwheat Book of the Dead: a two-act musical.

Warren is Back in the World: a two-act play.

Paul Robeson: a two-act play. By Phillip Hayes Dean. Prod. John Chenault. Dir. Harold Scott. Perf. Avery Brooks. Midwest Premiere, Taft Theater, Cincinnati, OH. 13-17 Feb. 1990. 
1986

1972

1971

1967-Present

1995-Present

1995-1997

1995-1996

1993-1996
Where Angels Piss: a two-act play.

Young Men Grow Older: half-hour television drama. By John Chenault. Dir. Charles Holmond. Prod. Jerome Manigan. Nominated for Emmy Award for Community Television (1972). Received National Conference of Christian \& Jews Brotherhood Award (1972). Premiered, WLW TV: Avco Broadcasting, Cincinnati, OH. 17 Dec. 1972.

Blood Rituals: a two-act musical. Commissioned for the National Conference of Social Workers. By John Chenault. Dir. Charles Holmond. Perf. Black Arts Ensemble.

Premiered, Cincinnati Playhouse, Cincinnati, OH. 12 Sept. 1971.

\section{$\underline{\text { Recording }}$}

"Afro-American Fragments." By Langston Hughes, Frank Proto, and John Chenault. Cond. Frank Proto. Perf. Ensemble Sans Frontiere, featuring narrator Charles Holmond, violinist John Blake. Distributed by Red Mark Records. Recorded, Ultrasuede Studios, Cincinnati, OH. Jan. 22, Oct. 17, Nov. 16, 1997.

\section{Memberships/Volunteer Affiliations}

Free Theatre, Cincinnati, OH. (Lifetime Member).

American Society of Composers, Authors and Publishers, (ASCAP) (Member).

Wilmington College Prison Program, Warren Correctional Institution, Warren, OH. (Volunteer Lecturer/Instructor).

Seventh Step Foundation, Cincinnati, OH. (Volunteer). Amethyst Ensemble, Cincinnati, OH. (Board Member). 